\title{
Methane-derived authigenic carbonates from the uppermost Doushantuo Formation in South China: Was the Ediacaran Shuram Excursion a globally synchronized early diagenetic event?
}

Huan Cui $^{\text {a,b,*, }}{ }^{\text {, Alan J. Kaufman }}{ }^{\text {b }}$, Shuhai Xiao ${ }^{c}$, Chuanming Zhou ${ }^{\text {d }}$, Xiao-Ming Liu ${ }^{\text {e }}$

\begin{abstract}
The Ediacaran Period is characterized by the most profound negative carbon isotope $\left(\delta^{13} \mathrm{C}\right)$ excursion in Earth history, the Shuram Excursion. Various hypotheses - including the massive oxidation of dissolved organic carbon (DOC) in the oceans, the weathering of terrestrial organic carbon, or the release and oxidation of methane hydrates and/or expelled petroleum from the subsurface - have been proposed as sources of the ${ }^{13} \mathrm{C}$-depleted carbon. More recently, it has been suggested that global-scale precipitation of early authigenic carbonates, driven by anaerobic microbial metabolism in unconsolidated sediments, may have caused the Shuram Excursion, but empirical evidence is lacking. Here we present a comprehensive analysis of a Shuram-associated interval from the uppermost Doushantuo Formation in South China. Our study reveals petrographic evidence of methane-derived authigenic calcite (formed as early diagenetic cements and nodules) that are remarkably depleted in ${ }^{13} \mathrm{C}$ - suggesting a buildup of alkalinity in pore fluids through the anaerobic oxidation of methane (AOM) - and systematically depleted in ${ }^{18} \mathrm{O}$
\end{abstract}


31 relative to co-occurring dolomite. Early authigenesis of these minerals is likely to be driven by

32 increased microbial sulfate reduction, triggered by enhanced continental weathering in the

33 context of a marked rise in atmospheric oxygen levels. In light of the finding of methane-derived

34 authigenic carbonates at Zhongling, and based on our basin-scale stratigraphic correlation, we

35 hypothesize that the marked ${ }^{13} \mathrm{C}$ and ${ }^{18} \mathrm{O}$ depletion (including their co-variation noted worldwide)

36 in the Shuram Excursion may reflect an episode of authigenesis occurring within a sulfate-

37 methane transition zone (SMTZ). If true, the Shuram Excursion was then a global

38 biogeochemical response to enhanced seawater sulfate concentration in the Ediacaran ocean

39 driven by the Neoproterozoic oxidation of surface environments. This paleo-oceanographic

40 transition may have therefore paved the way for subsequent evolution and diversification of

41 animals. Our study highlights the significance of the integrated approach that combines

42 petrography, mineralogy, and texture-specific micro-drilling geochemistry in chemostratigraphic

43 studies. Such investigation on fully-expressed Shuram-equivalent sections may hold the promise

44 to directly test our hypothesis.

Keywords: Shuram Excursion; Authigenic carbonate; Early diagenesis; Ediacaran Period;

47 Sulfate-methane transition zone (SMTZ); Anaerobic oxidation of methane (AOM);

48 Neoproterozoic Oxygenation Event (NOE)

\section{Introduction}

On geological time scales, the global carbon cycle involves the exchange of carbon

51 reservoirs between the atmosphere, the hydrosphere, and the deep mantle (Hayes and Waldbauer,

52 2006). The carbon flux derived from the mantle via volcanic outgassing is transferred to the rock

53 record in the form of carbonates and organic carbon, which are subsequently subducted back into

54 the mantle, thereby completing the long-term carbon cycle (Schidlowski, 1987; Hayes, 1994;

\section{Kump and Arthur, 1999).}

Authigenic carbonates are not usually addressed specifically in models of the global

57 carbon cycle, although they could potentially be an important flux in carbonate burial and thus

58 play an important role. Authigenesis (i.e., the process of authigenic mineralization) refers to any

59 post-depositional processes, includes early diagenesis related to both seawater and meteoric

60 alteration, or late diagenesis during deep burial. Authigenic carbonates formed during early 
61 diagenesis may be particularly important to the global carbon cycle (Schrag et al., 2013) insofar

62 as they are normally formed under the influence of anaerobic microbial processes, including

63 sulfate or iron reduction, which modify pore water chemistry and result in the dissolution,

64 replacement, or cementation of pre-existing marine sediments (Berner, 1981; Kastner, 1999;

65 Glenn et al., 2000; Lein, 2004; McMurtry, 2009). It has been suggested that modern authigenic

66 carbonate accounts for at least $10 \%$ of the global carbonate burial (Sun and Turchyn, 2014), and

67 this proportion may have been significantly larger in the Precambrian oceans (Schrag et al., 2013)

68 given that these were not fully oxygenated (Kah et al., 2004; Canfield et al., 2008; Lyons et al.,

69 2014; Planavsky et al., 2014; Sperling et al., 2015; Liu et al., 2016).

Largely based on numerical modelling (Higgins et al., 2009), it was hypothesized that authigenic carbonates may have played a critical role in the Precambrian carbon cycle (Schrag et

72 al., 2013). The Shuram Excursion in the Ediacaran Period (ca. 635-541 Ma) (Grotzinger et al.,

73 2011; Xiao et al., 2016) presents an ideal opportunity to test this hypothesis. The Shuram

74 Excursion in Oman is characterized by carbonate $\delta^{13} \mathrm{C}$ values that plunge to a nadir of ca. $-12 \%$

75 over a short stratigraphic interval and then rise steadily over hundreds of meters before

76 recovering to baseline values (Burns and Matter, 1993; Fike et al., 2006; Le Guerroué, 2006).

77 This profound carbon cycle anomaly is further characterized by: (1) covariations of carbon and

78 oxygen isotopes in carbonates (Derry, 2010a; Grotzinger et al., 2011), (2) decoupling between

79 carbonate carbon and organic carbon isotope compositions (Fike et al., 2006; McFadden et al.,

80 2008; Lee et al., 2013), (3) a strong negative $\delta^{34} \mathrm{~S}$ excursion recorded in both pyrite and

81 carbonate-associated sulfate (CAS) (Fike et al., 2006; Kaufman et al., 2007; McFadden et al.,

82 2008), and (4) a continuous increase in ${ }^{87} \mathrm{Sr} /{ }^{86} \mathrm{Sr}$ isotopes (Melezhik et al., 2009; Sawaki et al.,

83 2010; Cui et al., 2015; Xiao et al., 2016). This negative $\delta^{13} \mathrm{C}$ excursion may result from the

84 influence of ${ }^{13}$ C-delpeted authigenic carbonates (Macdonald et al., 2013; Schrag et al., 2013; Cui

85 et al., 2016c), but to evaluate this possibility requires new detailed petrographic and geochemical 86 data.

87 A pronounced negative $\delta^{13} \mathrm{C}$ excursion in the uppermost Doushantuo Formation in the

88 Yangtze Gorges area of South China is widely regarded as an equivalent of the Shuram

89 Excursion (Jiang et al., 2007; McFadden et al., 2008; Lu et al., 2013; Tahata et al., 2013; Zhu et

90 al., 2013; Wang et al., 2016; Xiao et al., 2016). However, this excursion is only expressed by a

91 few negative $\delta^{13} \mathrm{C}$ data points in outer-shelf environment (Zhou and Xiao, 2007; Zhu et al., 2007; 
$92 \mathrm{Li}$ et al., 2010). It is the inconsistent chemostratigraphic expression of this excursion between 93 intra-shelf and outer-shelf environments that drew our initial attention (Cui et al., 2015). In this

94 study, we present a comprehensive sedimentological, petrographic, and geochemical analysis of

95 carbonates in both depositional and authigenic phases preserved in the Doushantuo Formation at 96 the outer-shelf Zhongling section, and explore the biogeochemical origin and potential causal

97 link to the global Shuram Excursion.

\section{Materials and methods}

This study is focused on the Doushantuo Formation at two sections in South China including the intra-shelf Jiulongwan section at the Yangtze Gorges area and the outer-shelf Zhongling section in Hunan Province (Fig. 1). The detailed geology of these sections has been described in previous publications (see McFadden et al., 2008; Jiang et al., 2011; Cui et al., 2015;

103 Cui et al., 2016c). The Jiulongwan section preserves a typical Shuram Excursion (i.e., the EN3 104 interval in McFadden et al., 2008), with carbonate $\delta^{13} \mathrm{C}$ values consistently around - 9\%o in the upper 50 meters of the Doushantuo Formation. In contrast, the upper 50 meters of the Doushantuo Formation at the Zhongling section is characterized by highly variable $\delta^{13} \mathrm{C}$ values, 107 with only a few data points reaching nadir values of ca. - 5\%o (Zhu et al., 2007; Li et al., 2010; 108 Cui et al., 2015). In the field, the upper 50 meters of the Doushantuo Formation at Zhongling is 109 mainly composed of intraclastic, oolitic, or fine-grained dolomitic facies associated with three 110 discrete levels of phosphorite, suggesting deposition in an outer shelf carbonate shoal 111 environment (Jiang et al., 2011; Cui et al., 2015) (Figs. 2, 3).

112 The entire Doushantuo Formation at Zhongling was systematically sampled at high 113 stratigraphic resolution. Detailed sedimentological observations were made in the field. During 114 sampling, we observed centimeter-scale, white-colored calcite nodules that are distributed along 115 sedimentary bedding in dolostone or phosphorite facies, as well as distinct white-colored calcite 116 cement among dolomitic or phosphatic intraclasts (Figs. 2G-J). Late stage calcite veins were 117 also observed in the host carbonates, and they often cross-cut sedimentary bedding (Figs. 2G-H).

118 To provide a texture-resolved chemostratigraphy, detailed petrographic observation (Figs. 3, 4) 119 and geochemical analysis of micro-drilled powders (Figs. 5-7) were conducted. All isotope 120 analyses were performed using routine methods (e.g., McFadden et al., 2008; Cui, 2015; $\underline{\text { Cui et }}$ 121 al., 2015; Cui et al., 2016a; Cui et al., 2016b; Cui et al., 2016c), which are briefly outlined below. 
Carbonate carbon $\left(\delta^{13} \mathrm{C}_{\text {carb }}\right)$ and oxygen $\left(\delta^{18} \mathrm{O}_{\text {carb }}\right)$ isotopes were measured by continuous-

123 flow isotope ratio mass spectrometry in the Paleoclimate Laboratory at the University of

124 Maryland (UMD). Samples loaded into $3.7 \mathrm{~mL}$ Labco Exetainer vials and sealed with Labco

125 septa were flushed with $99.999 \%$ Helium and manually acidified at $60{ }^{\circ} \mathrm{C}$. The $\mathrm{CO}_{2}$ analyte gas

126 was isolated via gas chromatography, and water was removed using a Nafion trap prior to

127 admission into an Elementar Isoprime stable isotope mass spectrometer fitted with a continuous

128 flow interface. Data were corrected via automated MATLAB scripting on the VPDB and LSVEC

129 scale using periodic in-run measurement of international reference carbonate materials and in-

130 house standard carbonates, from which empirical corrections for signal amplitude, sequential

131 drift, and one or two-point mean corrections were applied (Evans et al., 2016). Both isotopes are

132 reported relative to VPDB. Precision for both is routinely better than $0.1 \%$.

Strontium isotopes $\left({ }^{87} \mathrm{Sr} /{ }^{86} \mathrm{Sr}\right)$ were analyzed for selected limestone and calcite nodule samples at the UMD Thermal Ionization Mass Spectrometer (TIMS) lab. Detailed method has been fully described in our previous publications (Cui et al., 2015; Cui et al., 2016a; Cui et al., 2016c). Final data have been corrected for instrumental fractionation using the standard value ${ }^{86} \mathrm{Sr} /{ }^{88} \mathrm{Sr}=0.1194$. Repeated analysis of the NBS SRM987 standard yields an average value of ${ }^{87} \mathrm{Sr} /{ }^{86} \mathrm{Sr}=0.710245 \pm 0.000011(2 \sigma)$ during the analytical window. Major and trace elemental abundances of micro-drilled carbonates in both depositional phases and authigenic phases were analyzed for a few representative samples in order to better evaluate the degree of diagenetic alteration. Aliquots of the micro-drilled carbonate powders

142 were dissolved in $0.4 \mathrm{M} \mathrm{HNO}_{3}$, centrifuged, and only analyzed for the solutions. Petrographic 143 observations indicate that these powders were largely free of siliciclastics; any clays, if present, 144 would not have been dissolved by the dilute acid. The resulting solutions were analyzed on a 145 Thermo Scientific $®$ iCAP-Q ICP-MS (Inductively Coupled Plasma - Mass Spectrometry) at the 146 Carnegie Institution of Washington. Precision of these analyses as determined by repeated

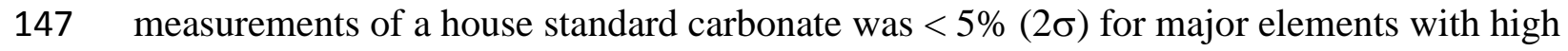
148 concentrations and $<10 \%(2 \sigma)$ for the REEs.

149 In order to better evaluate the diagenetic effect and quantitatively constrain the 150 mineralogical abundances, we also conducted detailed petrographic observation and 151 mineralogical analysis of representative samples using backscattered electron (BSE) imaging, 152 elemental mapping, quantitative X-ray powder diffraction (XRD), and cathodoluminescence (CL) 
153 imaging in the X-ray Crystallographic Center at UMD, the Geobiology Laboratory at Virginia

154 Tech, and the CL Laboratory at the Smithsonian Institution.

155

156

157

158

159

160

161

162

163

164

165

166

167

168

169

170

171

172

173

174

175

176

177

178

179

180

181

182

\section{Sedimentology, petrography, and paragenesis}

Detailed petrographic observations (Figs. 3, 4) were conducted in order to reconstruct the paragenesis of multiple mineralogical phases in the Doushantuo Formation. In the samples studied here, the well-preserved dolostone or phosphorite include intraclasts, peloids, and ooids (Figs. 3C-F), suggesting a shallow marine shelf depositional environment. Well-preserved sandsized phosphatic ooids generally have homogeneous fine-grained phosphatic cores coated with multiple cortical layers of dolomicrite (Figs. 3E, F).

Based on the occurrence of phosphatic allochems and oolite, the bedded fine-grained dolostone and phosphorite were likely to have formed in well agitated seawater, and then dolomitized in the outer-shelf environment during very early diagenesis. Like most wellpreserved Proterozoic dolostones, the Doushantuo dolostones are pervasively fine-grain sized, which are typically interpreted to record either primary precipitation, or very early dolomitization in marine environments (Tucker, 1982; 1983; Tucker and Wright, 1990). No mineralogical evidence for the metamorphic growth of silicate mineral phases was observed in the thin sections.

To various degrees, the phosphorite and dolostone were dissolved, replaced, and cemented by authigenic quartz and calcite (Fig. 4). The most distinct feature we observed in the field is the occurrence of white-colored calcite nodules aligned with sedimentary bedding in the upper section (Fig. 2G-J). These calcite nodules are primarily composed of coarse euhedral calcite crystals, which appear as coalesced patches under microscopic observation. Coarse calcite may also fill remaining voids among intraclasts and ooids (Fig. 4). Most of the calcite nodules are lined with a silica rim. Quartz crystals in the rim grow centripetally inward towards the center of the nodule, suggesting that they formed prior to, or about simultaneously with the calcite (e.g., Xiao et al., 2010; Cui et al., 2016c). Under CL microscopy, the calcite phase is dull and quartz is black (Fig. 4I). It is also notable that disseminated pyrite is widespread in the studied samples (Fig. 3H, I) (Cui et al., 2016c).

Based on the above petrographic observation, together with similar observation in the

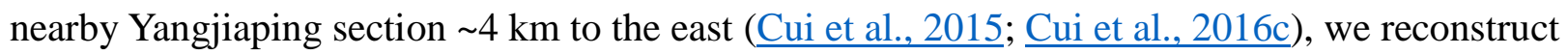


183 the following paragenetic sequence. (1) Dissolved phosphate in the water column was

184 transported to the marine sediments via the "Fe-P shuttle" (Shaffer, 1986; Glenn et al., 1994;

185 Muscente et al., 2015; Cui et al., 2016c). The release of Fe-bound phosphorous in the iron

186 reduction zone after deposition raised pore-water phosphate supersaturation levels, resulting in

187 the precipitation of authigenic phosphate along with dolomite. (2) The presence of phosphatic intraclasts and oolitic dolostone suggests sedimentary reworking and local transportation in a high-energy shoal environment. (3) After final deposition, these allochems were cemented by authigenic calcite, or replaced by authigenic calcite and quartz as distinct nodules forming along bedding planes. (4) Late-stage calcite veins also occur in some intervals, which cross cut sedimentary bedding planes and must have formed after the sediments were lithified. In summary, the Doushantuo samples from the shallow outer-shelf region at Zhongling recorded primary depositional and authigenic events in the sedimentary environment.

\section{Geochemical results}

\subsection{Geochemical analysis by micro-drilling}

After petrographically characterizing the sedimentary textures and minerals, various carbonate fabrics were micro-drilled and analyzed for $\delta^{13} \mathrm{C}$ and $\delta^{18} \mathrm{O}$ compositions (Figs. 5-7, Table S1-2) in order to construct chemostratigraphic profiles (Fig. 8). Within the scale of a single hand sample, we find marked heterogeneity in both $\delta^{13} \mathrm{C}$ and $\delta^{18} \mathrm{O}$ compositions. The $\delta^{13} \mathrm{C}$ of authigenic calcite phases reveals extraordinarily negative values, ranging from ca. -5 to as low as $-37 \%$, whereas the dolomitic or phosphatic matrices ranges from ca. -2 to $+7 \%$. Similarly, authigenic calcite phases preserve more negative $\delta^{18} \mathrm{O}$ values (ca. $-9 \%$ ) compared with

204 depositional phases (ca. -5\%). The lower 200 meters of the Doushantuo Formation at the Zhongling section (Figs. 2A-D) have also been carefully investigated, but no distinct calcite nodules were found at lower levels (Fig. S1). Thus, the phase-correlated $\delta^{13} \mathrm{C}_{\text {carb }}$ and $\delta^{18} \mathrm{O}_{\text {carb }}$

207 heterogeneity is only restricted to the upper 60 meters of the Zhongling section (Figs. 8J, K). representative samples in order to compare primary depositional and secondary authigenic

210 phases and to evaluate the overall degree of diagenetic alteration. In this regard, both dolomite 211 matrices and authigenic calcites were micro-drilled. In all the analyzed samples, authigenic 
212 calcites had significantly higher Sr concentration and much lower Fe, Mn, and Rb concentration

213 when compared with the dolomite matrix (Table S3). In addition, ${ }^{87} \mathrm{Sr} /{ }^{86} \mathrm{Sr}$ compositions of the

214 authigenic white calcite nodules and cements (ranging from 0.7080 to 0.7083 among all samples)

215 are typically less radiogenic than the dark-colored dolomitic phase (range from 0.7080 to 0.7088

216 among all samples) in which they are hosted (Figs. 5A, 6A, 6B, 9A).

217

218

219

220

221

222

223

224

225

226

227

228

229

230

231

232

233

234

235

236

237

238

239

240

\subsection{Compiled chemostratigraphic profiles}

The chemostratigraphic data are plotted using different symbols in the illustrations so that different texture, mineralogy, and paragenetic stages can be better distinguished and evaluated during interpretation. Chemostratigraphic profiles of the Doushantuo Formation at the intra-shelf Jiulongwan section and outer-shelf Zhongling section reveal many similarities, but also some distinct variations. For example, the $\delta^{13} \mathrm{C}_{\text {carb }}$ profile of the Doushantuo at Jiulongwan (Fig. 8A) shows three pulsed Ediacaran Negative (EN) excursions: EN1 in the basal cap carbonate, EN2 in the middle section, and EN3 at the top (McFadden et al., 2008). EN2 has been proposed to be correlated with the middle Ediacaran Gaskiers glaciation (Tahata et al., 2013), although this age assignment remains a matter of intense debate (Narbonne et al., 2012; Xiao et al., 2016). EN3 is widely regarded as an equivalent of the Shuram Excursion recognized worldwide (Jiang et al., 2007; McFadden et al., 2008; Grotzinger et al., 2011). However, $\delta^{13} \mathrm{C}_{\text {carb }}$ profile of typical marine carbonates at Zhongling reveals only a few scattered and moderately negative data points (Fig. $8 \mathrm{~J})$. Plotting our data from authigenic calcite phases, the integrated $\delta^{13} \mathrm{C}_{\text {carb }}$ profile at Zhongling

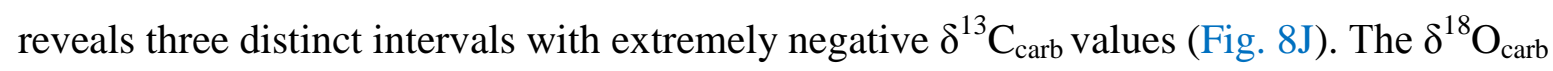
profile of the EN3 interval at Jiulongwan show an overall negative excursion down to - 10\%o, which broadly co-varies with the $\delta^{13} \mathrm{C}_{\text {carb }}$ profile (Fig. $8 \mathrm{~B}$ ). In contrast, the $\delta^{18} \mathrm{O}_{\text {carb }}$ profile at Zhongling preserves three small and discrete negative excursions corresponding to the three negative $\delta^{13} \mathrm{C}_{\text {carb }}$ spikes (Fig. $8 \mathrm{~K}$ ).

Compared to the record of carbonate carbon isotope variations, the $\delta^{13} \mathrm{C}_{\text {org }}$ profile at Jiulongwan is generally invariant with ca. - 30\%o values through most of the section, with the exception of an abrupt decrease down to almost - 40\%o in the uppermost black shale interval (Fig. 8C)(McFadden et al., 2008). At Zhongling, the $\delta^{13} \mathrm{C}_{\text {org }}$ profile in the lower 40 meters shows an overall increase that parallels the corresponding $\delta^{13} \mathrm{C}_{\text {carb }}$ profile, and then remains steady at ca. - 
$24125 \%$, with only a slight decrease toward the top of the section (Fig. 8L). It is notable that the

$242 \delta^{13} \mathrm{C}_{\text {carb }}$ and $\delta^{13} \mathrm{C}_{\text {org }}$ profiles at the uppermost Doushantuo Formation are decoupled, which has

243 similarly been observed in Shuram equivalent strata in Oman (Fike et al., 2006; Lee et al., 2013;

244 Lee et al., 2015) and Australia (Calver, 2000).

245 Sulfur and strontium isotope profiles in the inner and outer shelf sections also reveal 246 significant differences. The $\delta^{34} \mathrm{~S}$ profiles based on both pyrite and carbonate-associated sulfate

247 (CAS) analyses at Jiulongwan record parallel negative trends from $0 \%$ to $-20 \%$, and from $+20 \%$ o

248 to 0\%, respectively, in the EN3 interval (Fig. 8D) (McFadden et al., 2008). However, at the

249 Zhongling section, $\delta^{34} \mathrm{~S}$ values of pyrite and CAS remain invariant at around $+20 \%$ and $+40 \%$,

250 respectively (Fig. 8M). At the intra-shelf Jiulongwan section, ${ }^{87} \mathrm{Sr} /{ }^{86} \mathrm{Sr}$ values are consistently

251 low (ca. 0.7080) throughout most of the Doushantuo Formation, with a notable rise from 0.7080

252 up to 0.7090 during the EN3 interval (Fig. 8E) (Sawaki et al., 2010). In contrast, ${ }^{87} \mathrm{Sr} /{ }^{86} \mathrm{Sr}$ data

253 measured from calcite/limestone phases of the Zhongling section remain steady at ca. 0.7080 in

254 most of the section except for a slight rise to 0.7083 in the uppermost 10 meters (Fig. 8N).

255

256

257

258

259

260

261

262

263

264

265

266

267

268

269

\subsection{Co-variation of carbonate $\delta^{13} C$ and $\delta^{18} O$}

Pervasively fine-grained carbonates with alternating calcite and dolomite-rich laminations from the upper Doushantuo Formation show strong heterogeneity of $\delta^{13} \mathrm{C}_{\mathrm{carb}}$ and $\delta^{18} \mathrm{O}_{\text {carb }}$ on a centimeter-scale (Figs. 5-7, 9). For example, specimen 12ZL-49.8 (Fig. 9) - which has a grain size typical of most Ediacaran carbonates, including those deposited during the Shuram Excursion - reveals different proportional abundances of fine-grained dolomicrite and authigenic calcite in alternating sedimentary layers (Figs. 9B-E). The $\delta^{13} \mathrm{C}_{\text {carb }}$ and $\delta^{18} \mathrm{O}_{\text {carb }}$ data from each layer fall onto a well-correlated mixing line (Fig. 9F) with one end member represented by the depositional dolomicrite phase $\left(\delta^{13} \mathrm{C}_{\text {carb }}=\right.$ ca. $+3 \%$ and $\delta^{18} \mathrm{O}_{\text {carb }}=$ ca. $-5 \%$ ) and the other by the authigenic calcite phase $\left(\delta^{13} \mathrm{C}_{\text {carb }}=\right.$ ca. $-34 \%$ and $\delta^{18} \mathrm{O}_{\text {carb }}=$ ca. $-10 \%$ o $)$

XRD analyses of each layer were employed to quantify the abundance of depositional dolomicrite and authigenic calcite (Fig. S2, Table S4). We found that the magnitude of ${ }^{13} \mathrm{C}$ - and ${ }^{18} \mathrm{O}$-depletion in each layer is strongly dependent on the relative abundance of authigenic calcite (Figs. 9F-I). Notably, the $\delta^{13} \mathrm{C}_{\text {carb }}$ data range widely over $40 \%$ (from ca. $+3 \%$ o to $-34 \%$ ), while $\delta^{18} \mathrm{O}_{\text {carb }}$ data have a relatively narrow range (from ca. $-5 \%$ to $-10 \%$ ) in this sample. Similar 
270 mineralogical and isotopic systematics were noted in additional samples from different horizons

271 in the Zhongling section (Fig. 10).

273 5. Discussion

\section{5.1. An early authigenic origin for the ${ }^{13}$ C-depleted calcite}

275 5.1.1. Integrated sedimentological, petrographic, and geochemical evidence

276

277

278

279

280

281

282

283

284

285

286

287

288

289

290

291

292

293

294

295

296

297

Based on our detailed sedimentological, petrographic and geochemical analyses, we interpret the calcite nodules and cements from the upper Doushantuo Formation at Zhongling as early authigenic in origin having formed in unconsolidated sediments at or near the seafloor. At Zhongling, the preservation of authigenic calcite in nodules, cements, and fine-grained micrite intimately mixed with dolomicrite is associated with the three bedded phosphatic horizons (Fig. 2G-J). Due to preferentially weathering of calcite, weathered surfaces reveal an alternation of micrite- and dolomicrite-dominated laminations (Fig. 2G). No visible change in lithology or porosity was found within the phosphorite or dolostone horizons, nor did we observe any latestage karst or metamorphic features that would otherwise suggest very late growth and preservation of the nodules.

In contrast to the calcite nodules and cements, the late-stage calcite veins are not strongly depleted in ${ }^{13} \mathrm{C}$ (most have $\delta^{13} \mathrm{C}$ values > - 5\% ; Figs. S1D-F, 5B, 5F, 5H, 6C, 6D, 6F), but are notably more depleted in ${ }^{18} \mathrm{O}$ (Fig. 8K). The carbon and oxygen isotope contrast between bedcutting calcite veins and the horizontally aligned calcite nodules suggests that the two calcitic textures were not precipitated from the same fluids, and that the late-stage veins likely developed from hydrothermal waters during deep burial.

Further support for an early authigenic origin of the ${ }^{13} \mathrm{C}$-depleted calcite nodules and cements comes from their ${ }^{87} \mathrm{Sr} /{ }^{86} \mathrm{Sr}$ compositions and elemental abundances. Within each single sample, ${ }^{87} \mathrm{Sr} /{ }^{86} \mathrm{Sr}$ of dark-colored dolomitic phases (ranging from 0.7080 to 0.7088 ) are typically slightly more radiogenic than white-colored calcite phases (ranging from 0.7080 to 0.7083 ). This is the likely consequence of Sr loss during dolomitization and the addition of ${ }^{87} \mathrm{Sr}$ from ${ }^{87} \mathrm{Rb}$ decay in admixed clay minerals. On the other hand, the compositions of the calcite phases are 
298

remarkably consistent with contemporaneous Ediacaran seawater values recorded globally (Burns et al., 1994; Melezhik et al., 2009; Sawaki et al., 2010; Cui et al., 2015; Xiao et al., 2016), including bedded limestones lower in the Doushantuo Formation (Fig. 8N). Thus, the calcite nodules and cements are likely to more accurately reflect seawater $\mathrm{Sr}$ isotope compositions than the dolomites and phosphorites in which they are hosted. Elemental analyses for selected samples further indicate that calcite phases have much higher $\mathrm{Sr}$ concentration and much lower $\mathrm{Fe}, \mathrm{Mn}$, and Rb concentration when compared with dolomite matrices (Table S3), supporting their early authigenic origin. Similarly cathodoluminescence (CL) imaging of our samples show very dull color for the authigenic calcite nodules (Fig. 4I), which is consistent with the early diagenesis origin.

\subsubsection{Comparison with methane-derived authigenic carbonates in cap carbonates}

Similar to the calcite nodules and cements we have identified from the uppermost Doushantuo Formation, calcite with strong ${ }^{13} \mathrm{C}$ depletion also occurs as discrete textures in the cap dolostone at the base of the unit in the Yangtze Gorges area. On one hand, these isotopically anomalous calcites have been proposed as remnants of the oldest cold seep deposits, which formed during destabilization of methane hydrates in the aftermath of Marinoan glaciation (Jiang et al., 2003; Jiang et al., 2006a; Jiang et al., 2006b; Wang et al., 2008; Zhou et al., 2010; Zhou et al., 2016). On the other, the same phases have been re-interpreted as the result of postdepositional hydrothermal events, based on petrographic observation (Lin et al., 2011), clumped isotope analyses (Bristow et al., 2011), and combined organic matter and clay mineral analysis (Derkowski et al., 2013). Notably, the ${ }^{87} \mathrm{Sr} /{ }^{86} \mathrm{Sr}$ ratios in the basal Doushantuo cap dolostone are highly radiogenic (up to ca. 0.7130) (Fig. 8E), and furthermore these phases are spectacularly enriched in Mn (over 20,000 ppm resulting in Mn/Sr up to 600) (Sawaki et al., 2010; Bristow et al., 2011; Huang et al., 2011). These observations suggest significant water-rock interaction after burial (Marshall, 1992; Jacobsen and Kaufman, 1999).

In contrast, the calcite nodules and cements discovered in this study from the upper Doushantuo Formation at Zhongling all preserve typical Ediacaran seawater ${ }^{87} \mathrm{Sr} /{ }^{86} \mathrm{Sr}$ values (ca. 0.7080), suggesting an early authigenic origin for these phases, which appear to have been in diffusive contact with a dominantly marine Sr source. Authigenic carbonates with seawater $\mathrm{Sr}$ signals are common in Modern marine sediments (e.g., Hovland et al., 1987; Aharon et al., 1997; 
328

329

330

331

332

333

334

335

336

337

338

339

340

341

342

343

344

345

346

347

348

349

350

351

352

353

354

355

356

Naehr et al., 2000; Greinert et al., 2001; Peckmann et al., 2001; Joseph et al., 2012). When marine sediments are still unconsolidated with free diffusion of Sr from seawater, authigenic carbonates will capture seawater $\mathrm{Sr}$ isotope compositions. The high concentration of $\mathrm{Sr}$ and low concentration of $\mathrm{Mn}, \mathrm{Fe}$ and $\mathrm{Rb}$ in the Zhongling authigenic calcite phases is also in strong contrast with those from the basal Doushantuo cap carbonate, which supports our view that each has a unique and dissimilar origin.

In summary, sedimentological, petrographic, and geochemical observations of the isotopically-distinct calcite phases from the uppermost Doushantuo Formation at Zhongling support the view that they are early authigenic in origin. They appear not to be associated with post-lithification hydrothermal events (e.g., Bristow et al., 2011; Derkowski et al., 2013; $\underline{\text { Hohl et }}$ al., 2015). Thus, we interpret the bedded, fine grain-sized, phosphatic or dolomitized carbonates as depositional phases, and these textually- and isotopically-distinct calcite cements and nodules as syndepositional authigenic phases.

\subsection{Mechanism for authigenic mineralization}

In our view, the biogeochemical processes responsible for authigenic mineralization in the uppermost Doushantuo sediments prior to lithification are directly related to variations in the pH and alkalinity of pore waters due to microbial activity (Fig. 11) (Walter et al., 1993;

Langmuir et al., 1997; Morse, 2003). Geochemical consideration of microbial sulfate reduction (Eq. 1), which is often coupled with the anaerobic oxidation of methane (Eq. 2), indicates that the onset of this metabolic activity initially lowers the $\mathrm{pH}$, which would favor the dissolution of the pre-existing carbonates (Eq. 3) (Birnbaum and Wireman, 1984; Morse and Mackenzie, 1990; Walter and Burton, 1990; Walter et al., 1993; Morse, 2003; Meister, 2013), as well as the precipitation of authigenic silica (Eq. 4) (Stage 1 in Fig. 11). The production of sulfide would result in the formation of pyrite so long as ferrous iron were available in the sediments, and the observation of spherical pyrite framboids (Fig. 3H, I) is a testament to this microbial process.

$\mathrm{SO}_{4}{ }^{2-}+2 \mathrm{CH}_{2} \mathrm{O} \rightarrow \mathrm{HS}^{-}+2 \mathrm{HCO}_{3}{ }^{-}+\mathrm{H}^{+}$(Eq. 1) (sulfate reduction) $\mathrm{SO}_{4}{ }^{2-}+\mathrm{CH}_{4} \rightarrow \mathrm{HS}^{-}+\mathrm{HCO}_{3}{ }^{-}+\mathrm{H}_{2} \mathrm{O}$ (Eq. 2) (anaerobic oxidation of methane) $\mathrm{CaCO}_{3}+\mathrm{H}^{+} \rightarrow \mathrm{Ca}^{2+}+\mathrm{HCO}_{3}^{-}$(Eq. 3) (dissolution of pre-existing carbonate) 


$$
\mathrm{SiO}_{3}^{2-}+\mathrm{H}^{+} \rightarrow \mathrm{SiO}_{2}+\mathrm{OH}^{-} \text {(Eq. 4) (authigenic silica formation) }
$$

As sulfate reduction progresses, however, the $\mathrm{pH}$ is stabilized and calcite saturation increases with the buildup of alkalinity (Morse and Mackenzie, 1990; Walter et al., 1993; Morse,

361 2003; Meister, 2013), especially if methane is the primary organic substrate (Moore et al., 2004)

362 (Stage 2 in Fig. 11). As alkalinity in pore waters rises and becomes increasingly saturated, the concomitant rise in $\mathrm{pH}$ would favor the dissolution of pre-existing silica and authigenic precipitation of ${ }^{13}$ C-depleted calcite (Eq. 5) (e.g., Berner, 1971; $\underline{\text { Ritger et al., 1987). }}$. intervals, microbial iron reduction during the phosphorite formation, which is also known as the "Fe-P shuttle" (Muscente et al., 2015; Cui et al., 2016c), may have also have played a role in the production of alkalinity and authigenic mineralization. Carbonate saturation would also increase during microbial iron reduction (Eq. 6) (Riedinger et al., 2014). Microbial reduction of FeOOH is a strong sink of $\mathrm{H}^{+}$that increases pore water $\mathrm{pH}$ and can promote carbonate precipitation (Coleman and Raiswell, 1995): reduction (Eq. 7) may also consume acidity and promote authigenic carbonate formation: and its authigenic formation may have been promoted by the coupling of sulfate and iron reduction by a consortium of micro-organisms. Ferrous iron in pore fluids could be produced by microbial iron reduction, and react with sulfide produced by microbial sulfate reduction to form authigenic pyrite (Eq. 8). 
$\mathrm{Fe}^{2+}+\mathrm{HS}^{-} \rightarrow \mathrm{FeS}+\mathrm{H}^{+} ; \mathrm{FeS}+\mathrm{S}^{0} \rightarrow \mathrm{FeS}_{2}$ (Eq. 8) (authigenic pyrite formation)

An integrated reaction combining microbial sulfate and iron reduction is summarized

392 below (Eqs. 9, 10):

$6 \mathrm{CH}_{2} \mathrm{O}+3 \mathrm{SO}_{4}{ }^{2-} \rightarrow 6 \mathrm{HCO}_{3}{ }^{-}+3 \mathrm{H}_{2} \mathrm{~S}$; (Eq. 9)

$2 \mathrm{FeOOH}+3 \mathrm{H}_{2} \mathrm{~S}+\mathrm{S}^{0} \rightarrow 2 \mathrm{FeS}_{2}+4 \mathrm{H}_{2} \mathrm{O}$ (Eq. 10) and cements, authigenic silica rim surrounding the calcite, and disseminated pyrite, recorded multiple stages of early authigenic mineral growth mediated by a consortium of microbes. This process is accompanied by varying $\mathrm{pH}$ conditions in pore water, and is controlled by the flux of sulfate, silicon, and iron from seawater through unconsolidated marine sediments.

\subsection{Conceptual model for the $\delta^{13}$ C anomaly}

\subsubsection{Progressive deepening of the sulfate-methane transition zone}

In the uppermost Doushantuo Formation at Zhongling, highly negative $\delta^{13} \mathrm{C}$ values (as low as $-37 \%$ ) of authigenic calcite suggest that the anaerobic oxidation of methane by microbial sulfate reduction occurred in pore waters within the sulfate-methane transition zone (SMTZ) (Fig. 12)(Jørgensen and Kasten, 2006; Xu, 2010). In modern marine environments rich in sulfate, the upward methane flux is exhausted in the SMTZ through sulfate reduction (Jørgensen, 1982), except in localized cold seeps where excess methane can escape to seawater (Greinert et al.,

411 transition within an anoxic sediment column where pore water sulfate and methane concentration 412 profiles intersect at non-detectable levels (Fig. 12C). The depth of SMTZ depends on the relative 413 size of upward methane flux from the depth and the downward diffusion of sulfate from 414 overlying seawater (Borowski et al., 1996; Borowski et al., 1999).

415 In light of the observation in this study, we propose that the anomalous negative $\mathrm{C}$

416 isotope signals in the uppermost Doushantuo Formation may have formed from syndepositional 
417 authigenesis in a shallow SMTZ. To allow for the progressive deposition of early authigenic

418 carbonates, we hypothesize that the inferred SMTZ was likely to be immediately below the

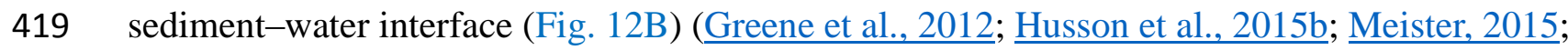

420 Saitoh et al., 2015). We realize that similar analogues in modern marine environments are

421 lacking, but insofar as redox conditions in terminal Proterozoic oceans were likely to be quite

422 different from those of the modern, a non-actualistic approach (e.g., Catling et al., 2007;

423 Grotzinger et al., 2011; Schrag et al., 2013; Meister, 2015; Zhou et al., 2015) is required in order

424 to reconcile the observations described above.

425 In modern marine sediments, the depth of SMTZ may vary strongly among different

426 localities, ranging from centimeter to hundreds of meters in scale depending on the water depth,

427 organic flux, and the balance between the downward flux of sulfate and the upward flux of 428 methane (Borowski et al., 1996; Borowski et al., 1999). Generally, the SMTZ is shallow where

429 the methane flux dominates (e.g., above localized gas hydrate reservoirs), and is deeper where

430 diffusion of seawater sulfate dominates the system. Insofar as marine sulfate concentration 431 progressively increased in the Neoproterozoic (Halverson and Hurtgen, 2007; Canfield and

432 Farquhar, 2009; Cui et al., 2016b), the position of the SMTZ in marine sediments may have been 433 initially located near the sediment-water interface, and then moved deeper over time in response 434 to the increasing flux of the oxidant (e.g., sulfate or iron oxide) as the result of elevated oxidative 435 weathering or an increase in bioturbation.

436 With the emergence of bioturbation in the terminal Ediacaran and Cambrian periods

437 (Bottjer et al., 2000; Carbone and Narbonne, 2014), ventilation of the deep ocean (Logan et al.,

438 1995; Butterfield, 2009; 2011; Lenton et al., 2014; Chen et al., 2015), and a larger seawater 439 sulfate pool (Halverson and Hurtgen, 2007; Canfield and Farquhar, 2009; Cui et al., 2016b), the 440 Phanerozoic SMTZ would have been progressively deeper compared with the SMTZ in

441 Precambrian time (Fig. 12C) (see Wright and Cherns, 2016 for a Phanerozoic analogue).

442 Conversely, during most of the Precambrian, due to the very low sulfate concentration in the 443 ocean, the SMTZ may not exist in marine sediments, and the biogenic methane flux may have 444 directly escaped into the atmosphere (e.g., Halverson et al., 2002; Pavlov et al., 2003; Catling et 445 al., 2007; Ader et al., 2009; Bristow and Grotzinger, 2013; Li et al., 2015; Shen et al., 2016) (Fig. 446 12A).

447 Our conceptual model offers an attractive scheme to explain the uniqueness of the 
448 Shuram Excursion in Earth's history. The stratigraphic expression of the Shuram Excursion may 449 have been triggered by a mid-Ediacaran development of a sulfate-methane transition zone near 450 the seafloor. Continuous syndeposition of early authigenic carbonates in this shallow redox zone 451 led to full expressions of the Shuram Excursions in stratigraphic records of continental marginal 452 areas where sulfate concentration increased to threshold levels (ca. $10 \mathrm{mM}$, see the next section 453 for quantitative constraints) in response to the Neoproterozoic Oxygenation Event. Overall low 454 sulfate condition during most of the Precambrian may have significantly inhibited the 455 development of the sulfate-methane transition zone (Catling et al., 2007), resulting in the lack of 456 Shuram-like excursions. Conversely, too high concentration (>10 mM) of seawater sulfate and 457 the emergence of bioturbation during most of the Phanerozoic may have played a role in driving 458 the sulfate-methane transition zone into much deeper depth, consequently switched the 459 depositional pattern of authigenic carbonates from syn-deposition to post-deposition. In summary, 460 the uniqueness of the Shuram Excursion in Earth's history may result from an overall irreversible 461 increase of seawater sulfate concentration, and an enhanced activity of bioturbation during the 462 Phanerozoic. These two factors may have influenced the depth of the sulfate-methane transition zone where syn-deposition or post-deposition of authigenic carbonates occurred.

\subsubsection{Quantitative constraint on seawater sulfate concentration}

If our conceptual model of shallow authigenesis holds true for the middle Ediacaran

467 Shuram Excursion, quantitative constraint on seawater sulfate concentration might be possible 468 (Fig. 12). In modern environment with sulfate concentration at ca. 28 mM (Star 3 in Fig. 12C), 469 methanogens are typically outcompeted for substrates (e.g. lactate and acetate) by sulfate 470 reducers, so the SMTZ is only developed when pore-water sulfate concentration is lower than ca.

$47110 \mathrm{mM}$ within the sediments (Jørgensen and Kasten, 2006) (Star 2 in Fig. 12C). Extrapolating 472 this sulfate threshold to a shallow SMTZ just beneath the sediment-water interface (Star 2 in Fig.

473 12B), the seawater sulfate concentration should have been no more than $10 \mathrm{mM}$ if authigenesis

474 occurs immediately above the sediment-water interface (evidenced by seafloor crystal fans in 475 some localities; Pruss et al., 2008; Hall et al., 2013; Loyd et al., 2013). At Zhongling, the sulfate 476 concentration in seawater might have been slightly higher than $10 \mathrm{mM}$ to allow the growth of 477 authigenic nodules in SMTZ within shallow marine sediments. This estimate is consistent with a 
478 recent model based on time-series sulfur isotope variation, which suggests that oceanic sulfate

479 concentration was low $(<5 \mathrm{mM})$ in the aftermath of the Marinoan ice age (ca. $635 \mathrm{Ma})$, but rose 480 sharply (to ca. $10 \mathrm{mM}$ ) near the Ediacaran-Cambrian boundary (Algeo et al., 2015).

\subsection{Origin of co-varying carbon and oxygen isotopes}

The recognition of alternating laminations dominated by micrite and dolomicrite in outcrop allowed for petrographic and isotopic tests of the authigenic hypothesis, and a possible connection to the Shuram Excursion. Several hypotheses have been proposed to interpret positive correlations between $\delta^{13} \mathrm{C}_{\text {carb }}$ and $\delta^{18} \mathrm{O}_{\text {carb }}$ (Fig. 13). The progressive increase of fluidrock interaction during carbonate diagenesis could cause different degrees of depletion of ${ }^{13} \mathrm{C}$ and ${ }^{18} \mathrm{O}$ (Jacobsen and Kaufman, 1999) . Based on simple box modeling, $\delta^{18} \mathrm{O}_{\text {carb }}$ could be reset more easily (i.e., less rock-buffered) than $\delta^{13} \mathrm{C}_{\text {carb }}$ compositions, thereby forming a hyperbolic relationship (Fig. 13A). This mechanism may be true for some sample sets (e.g., Lohmann, 1988; Bishop et al., 2014), but does not explain the linear relationship of $\delta^{13} \mathrm{C}_{\text {carb }}$ and $\delta^{18} \mathrm{O}_{\text {carb }}$ revealed in this study (Figs. 9, 10).

Based on the positive $\delta^{13} \mathrm{C}_{\mathrm{carb}}-\delta^{18} \mathrm{O}_{\text {carb }}$ correlations in modern marine sediments, which results from meteoric water alteration (e.g., Gross and Tracey, 1966; Quinn, 1991; Swart and Kennedy, 2012; Oehlert and Swart, 2014), Knauth and Kennedy (2009) interpreted similar observations in Ediacaran sedimentary rocks as a result of globally-distributed diagenetic event associated with the flushing of meteoric waters depleted in both ${ }^{13} \mathrm{C}$ and ${ }^{18} \mathrm{O}$ through shallow marine sediments. This model assumes a widespread terrestrial biosphere during the Ediacaran Period (Fig. 13B), and has been widely adopted as a universal criterion for diagenetic evaluation in chemostratigraphic studies (e.g., Xiao et al., 2012; Lu et al., 2013; Tahata et al., 2013; Osburn et al., 2015; Schobben et al., 2016).

503 of fluid-rock interactions associated with deep burial long after deposition (Fig. 13C) (Derry,

504 2010a; 2010b). Contrary to the Jacobsen and Kaufman (1999) model, which describes only

505 "passive" trace element or isotopic exchange, but does not include any chemical reactions

506 between fluid and rock, Derry (2010a) uses another approach. It takes an initial system 
507 containing fluid and minerals in equilibrium at a given temperature, and then this system reacts

508 with addition of a new infiltrating "reactant" fluid of a different composition at progressively

509 higher water/rock ratio. Thus mineral and fluid compositions are continuously re-calculated from

510 equilibrium relationships as the system composition evolves. This approach may better reflect

511 the pore water condition as the burial depth becomes progressively deeper. Indeed, with this

512 revised approach, the linear relationship in $\delta^{13} \mathrm{C}_{\text {carb }}$ vs. $\delta^{18} \mathrm{O}_{\text {carb }}$ could be well explained by this

513 model.

514 These hypotheses, however, are inconsistent with the excellent preservation of fine-

515 grained and texturally complex carbonates with geochemically-distinct and mineralogically-

516 dependent heterogeneity. For example, if meteoric water percolated the strata, we would expect

517 pervasive alteration, as opposed to the preservations of well aligned calcite nodules surrounded

518 by distinct quartz rim. Late diagenesis controlled by sediment porosity and permeability could

519 indeed cause strong heterogeneity (e.g., Moore, 1989; Moore, 2004; Ahr, 2011; Morad et al.,

520 2013), but this scenario can be ruled out considering the pervasively fine grained dolomicrite

521 host carbonates in the upper Doushantuo Formation. Moreover, both meteoric water alteration

522 and deep burial diagenesis could not sufficiently explain the extremely negative $\delta^{13} \mathrm{C}_{\text {carb }}$ and

523 typical Ediacaran seawater ${ }^{87} \mathrm{Sr} /{ }^{86} \mathrm{Sr}$ signals exclusively preserved in the calcite nodules. Thus,

524 we disfavor these diagenesis models as explanations for the covariance in $\delta^{13} \mathrm{C}_{\text {carb }}$ and $\delta^{18} \mathrm{O}_{\text {carb }}$

525 revealed in the Zhongling carbonates.

\section{5.4.2. An authigenic mixing model}

527 In light of the sedimentological, petrographic, and isotopic observation in the uppermost

528 Doushantuo Formation (Figs. 2-8), we propose that the strong $\delta^{13} \mathrm{C}_{\mathrm{carb}}-\delta^{18} \mathrm{O}_{\text {carb }}$ correlation likely

529 resulted from different degrees of authigenic carbonate mineralization (Fig. 13D). BSE images

530 reveal sedimentary layers of fine-grained dolomicrite with variable amount of authigenic calcite

531 (Fig. 9), resulting in $\delta^{13} \mathrm{C}_{\text {carb }}$ and $\delta{ }^{18} \mathrm{O}_{\text {carb }}$ compositions that fall on a mixing line between end-

532 member compositions. XRD analyses of each layer were employed to quantify the relative

533 abundance of depositional dolomicrite and authigenic calcite, and we found that the magnitude

534 of ${ }^{13} \mathrm{C}$ - and ${ }^{18} \mathrm{O}$-depletion is strongly dependent on the relative abundance of authigenic calcite 535 (Figs. 9H, I).

536 The differences in $\delta^{18} \mathrm{O}_{\text {carb }}$ compositions of the calcite and dolomicrite end members in 
537 our samples from Zhongling samples are on the order of ca. 5\%, with calcite being

538 systematically depleted in ${ }^{18} \mathrm{O}$ (Figs. 8K, 9, 10). This may reflect an isotope effect between

539 calcite and dolomite during precipitation or dolomitization. Both experimental studies (Northrop

540 and Clayton, 1966; O'Neil and Epstein, 1966; Sheppard and Schwarcz, 1970; Horita, 2014) and

541 natural samples (Degens and Epstein, 1964; Gross and Tracey, 1966; Sass et al., 1991; Metzger

542 and Fike, 2013; Li et al., 2016) have shown ca. + 5\% enrichment of ${ }^{18} \mathrm{O}$ in co-existing dolomite

543 relative to calcite forming from the same solution. This isotopic effect may be responsible for the

$544 \delta^{18} \mathrm{O}_{\text {carb }}$ variation during the mixing between authigenic calcite and depositional dolomite in the 545 studied samples.

It should be noted that the $\delta^{18} \mathrm{O}_{\text {carb }}$ compositions in both depositional phase and 548 authigenic phase are more negative than modern seawater values (ohling, 2007). To interpret 549 the $\delta^{18} \mathrm{O}_{\text {carb }}$ behavior in the studied rocks, the Ediacaran seawater $\delta^{18} \mathrm{O}$ composition would need 550 to be known a priori, but this remains a matter of ongoing debate. On one hand, lower seawater $551 \delta^{18} \mathrm{O}($ ca. - 7\% PDB) has been proposed for the Neoproterozoic ocean (Veizer et al., 1997;

552 Veizer et al., 1999; Kasting et al., 2006; Jaffrés et al., 2007), but on the other hand it has also

553 been argued that the seawater $\delta^{18} \mathrm{O}$ composition through Earth history may remain largely

554 constant (Muehlenbachs and Clayton, 1976; Muehlenbachs, 1998; Knauth, 2005).

555 If the Ediacaran seawater $\delta^{18} \mathrm{O}$ is consistent with the modern seawater value, then the 556 question becomes: what mechanism leads to the decrease of $\delta^{18} \mathrm{O}$ data in the Precambrian

557 carbonates, particularly in these authigenic calcite revealed form this study? In both the meteoric 558 water alteration model (Fig. 13B; Knauth and Kennedy, 2009) and the burial diagenesis model

559 (Fig. 13C; Derry, 2010a), the authors assumed that the Ediacaran seawater $\delta^{18} \mathrm{O}$ was

560 indistinguishable from the modern and they therefore proposed diagenetic alteration as the only 561 mechanism for the decrease of Precambrian $\delta^{18} \mathrm{O}$ carbonate values. However, this fundamental 562 assumption should be treated with caution given the controversial understanding of deep time $563 \delta^{18} \mathrm{O}$ evolution in the ocean (Arthur, 2009).

564 Alternatively, if the Ediacaran seawater $\delta^{18} \mathrm{O}$ composition is indeed much lower (e.g., $5657 \%$; Kasting et al., 2006; Jaffrés et al., 2007) than the modern seawater value, then the question 566 becomes: what mechanism leads the $\delta^{18} \mathrm{O}$ variability in mineralogically different carbonate 
567 phases towards opposite directions on a centimeter scale? As revealed from the uppermost 568 Doushantuo Formation at Zhongling, the depositional phase (i.e., pervasively fine-grained 569 dolomicrite) has generally higher $\delta^{18} \mathrm{O}$ values, while the early authigenic phase (i.e., methane570 derived calcite) have generally lower $\delta^{18} \mathrm{O}$ values.

$571 \quad$ Variation in the $\delta^{18} \mathrm{O}$ of seawater or pore water during early diagenesis can result from

572 local evaporation ( $\mathrm{Li}$ and Ku, 1997; Kah, 2000; Gomez et al., 2014; Horton et al., 2015), gas

573 hydrate formation (Davidson et al., 1983; Teichert et al., 2005; Kennedy et al., 2008; Nyman and

574 Nelson, 2011), or glacial ice buildup or melting (Zhao and Zheng, 2010; Peng et al., 2013; Wang

575 et al., 2014; Zhao and Zheng, 2015). Progressive changing in these environmental factors, or

576 end-member mixing among different reservoirs influenced by these factors could indeed cause

577 potential correlation in $\delta^{13} \mathrm{C}_{\text {carb }}$ vs. $\delta^{18} \mathrm{O}_{\text {carb }}$ (e.g., Li and Ku, 1997; Horton et al., 2015; Mishra et

578 al., 2015). However, to link these potential mechanisms to the uppermost Doushantuo Formation

579 requires a comprehensive evaluation based on integrated sedimentological, petrographic, and

580 geochemical observations. Right now, there is still no clear evidence for any of these

581 mechanisms. Lab experiments also reveal that solution $\mathrm{pH}$, alkalinity (Spero et al., 1997),

582 carbonate precipitation rate (Watkins et al., 2014), and salinity (Adkins et al., 2002) could also

583 influence the $\delta^{18} \mathrm{O}$ compositions. However, these effects are modest, only 1-2\%o at most.

584 The effect of early authigenesis on pore water $\delta^{18} \mathrm{O}$ compositions in natural marine 585 sediments remains largely unknown. Studies reveal that $\delta^{18} \mathrm{O}$ compositions of early authigenic 586 calcite are typically more depleted in ${ }^{18} \mathrm{O}$ than co-existing host carbonates (e.g., Sass et al., 1991;

587 Mozley and Burns, 1993; Melezhik et al., 2007). The detailed mechanism remains unclear, but 588 may be associated with either potential mixing of more ${ }^{18} \mathrm{O}$-depleted sources (e.g., pore water 589 sulfate, meteoric water, glacial meltwater) during very early diagenesis, or in situ precipitation of $590{ }^{18}$ O-enriched sinks (e.g., gas hydrate associated clathrate, clay minerals) within sediments.

591 Currently, there is still no data available to test these hypotheses.

592 Clumped isotope analyses of other time-equivalent strata (Bergmann, 2013; Loyd et al.,

593 2015) suggest different degrees of diagenetic overprint by increasing fluid-rock interaction

594 during deep burial. This in part supports the late diagenesis model proposed by Derry (2010a),

595 but could not reconcile with a variety of sedimentological observations that strongly point to an 596 early authigenic origin (Grotzinger et al., 2011). Thus, on one hand we recognize potential 597 diagenetic overprint in our samples (and probably in most carbonate samples of Precambrian 
598 age); on the other hand, we regard different degrees of authigenic mineralization during very 599 early diagenesis as the main reason for the tight $\delta^{13} \mathrm{C}_{\text {carb }}-\delta^{18} \mathrm{O}_{\text {carb }}$ correlation (Fig. 13D). suggest that the tight $\delta^{13} \mathrm{C}_{\mathrm{carb}}-\delta^{18} \mathrm{O}_{\text {carb }}$ correlation results from progressive mixing of authigenic 602 calcite in depositional dolomite (Figs. 9, 10). The ca. 5\%o range in $\delta^{18} \mathrm{O}_{\text {carb }}$ that is generally lower 603 than normal seawater values likely reflects a superimposed effect by both calcite-dolomite 604 fractionation and burial diagenesis as evidenced by clumped isotopes (Loyd et al., 2015). If true, 605 our data support the view that $\delta^{18} \mathrm{O}_{\text {carb }}$ is less rock-buffered and more sensitive to diagenetic 606 alteration than $\delta^{13} \mathrm{C}$ and ${ }^{87} \mathrm{Sr} /{ }^{86} \mathrm{Sr}$ (Lohmann, 1988; Banner and Hanson, 1990; Jacobsen and 607 Kaufman, 1999; Bishop et al., 2014; Loyd et al., 2015). However, to better interpret the overall 608 negative $\delta^{18} \mathrm{O}_{\text {carb }}$ compositions in both depositional and authigenic phases requires a better 609 understanding of the Ediacaran seawater $\delta^{18} \mathrm{O}_{\text {carb }}$ compositions, as well as the detailed knowledge about the effect of authigenesis on pore water $\delta^{18} \mathrm{O}_{\text {carb }}$ compositions.

\subsection{Shuram Excursion and deep-time carbon cycles}

\subsubsection{Correlation of the uppermost Doushantuo between Zhongling and Jiulongwan}

The variable expression of the $\delta^{13} \mathrm{C}$ negative excursion in the uppermost Doushantuo

614 Formation across the basin (Xiao et al., 2012; Lu et al., 2013; Cui et al., 2015; Wang et al., 2016)

615 hampers our interpretation of its origin and global implications (Fig. 8A, J). Construction of 616 composite chemostratigraphic sections should be based on a basin-wide analysis rather than from 617 measurements of any single section. Based on our integrated $\delta{ }^{13} \mathrm{C}-\delta^{34} \mathrm{~S}-{ }^{87} \mathrm{Sr} /{ }^{86} \mathrm{Sr}-\mathrm{Ce} / \mathrm{Ce} *$ 618 chemostratigraphy, we noted that EN3 at the Zhongling section and the nearby Yangjiaping 619 section is incompletely preserved or revealed, and accordingly we have suggested that the 620 uppermost Doushantuo Formation at Zhongling is likely to be correlated with the EN3a interval 621 at Jiulongwan (Cui et al., 2015; Cui et al., 2016c). Our revised correlation is also consistent with 622 the progressive shallowing in water depth on the basis of independent sedimentological 623 observation in the outer-shelf sections, where an increasing proportion of intraclasts and oolites 624 relative to fine-grained phases are deposited (Jiang et al., 2011; Cui et al., 2015). The missing $625 \mathrm{EN} 3 \mathrm{~b}$ and EN3c in the outer-shelf sections may be due to either a basin-wide unconformity ( $\underline{\mathrm{Lu}}$ 626 et al., 2013; Zhu et al., 2013; Wang et al., 2016), or the diachronous nature of the lithology 
627 boundary between Doushantuo and Dengying formations (Cui et al., 2015).

628 If our basin-scale correlation for the Doushantuo Formation is correct, the strongly ${ }^{13} \mathrm{C}$ 629 depleted authigenic signatures revealed from the uppermost Doushantuo Formation at Zhongling 630 could immediately precedes EN3, or could be time-equivalent to EN3a at the Jiulongwan section, 631 suggesting a potential linkage between methane oxidation, sea level regression, and the onset of 632 the Shuram Excursion (Bjerrum and Canfield, 2011). Indeed, sedimentological observations of 633 the Shuram Excursion from other sections in South China (Lu et al., 2013; Wang et al., 2016), 634 Death Valley (Summa, 1993; Corsetti and Kaufman, 2003; Kaufman et al., 2007; Bergmann et al., 635 2011), Oman (Fike et al., 2006; Le Guerroué et al., 2006b; Le Guerroué et al., 2006c; Lee et al., 636 2013; Osburn et al., 2014), South Australia (Husson et al., 2012; Husson et al., 2015b), and NW 637 Canada (Macdonald et al., 2013) have also revealed a regression immediately before the onset of

644 SMTZ (Torres et al., 1996; Jørgensen and Kasten, 2006; Riedinger et al., 2006; Feng and Roberts,

645 2011; Vanneste et al., 2013). When sulfate and organic carbon is available, a barite front forms in

646 the SMTZ where the flux of sulfate diffused from seawater meets with soluble barium diffusing 647 upward from depth. Thus, an enrichment in barium (typically as authigenic barite) has been 648 widely used as an indicator for the reconstruction of paleo SMTZs in deep time records (e.g., 649 Dickens, 2001; Dickens et al., 2003; Lash, 2015; Zhou et al., 2015; Niu et al., 2016). Trace 650 element analyses of the EN3 interval at Jiulongwan reveal a strong enrichment in barium (Fig. 651 14D). These measurements are consistent with independent sedimentological observations of 652 authigenic barite crystals closely associated with carbonate concretions and black shales (Fig. 653 S3E). The co-occurrence of authigenic calcite and authigenic barite has also been reported in 654 sedimentary rocks deposited during the short-lived Paleocene-Eocene Thermal Maximum 655 (PETM) when gas hydrate dissociation and methane oxidation was believed to have contributed 656 to the negative $\delta^{13} \mathrm{C}$ excursion (Dickens, 2001; Dickens et al., 2003). 
If the model of a shallow SMTZ is true for the Shuram Excursion, it could explain a

658 variety of sedimentological observations. For example, the Shuram Excursion is globally recorded by bedded micritic limestone (instead of dolomite) independent of sedimentary facies (Melezhik et al., 2009; Grotzinger et al., 2011; Bergmann, 2013; Lu et al., 2013; Husson et al., 2015b). The dominance of limestone in this interval may well reflects an episode of enhanced authigenic mineralization of calcite (or initially aragonite, see Husson et al., 2015a). Abundant seafloor-precipitated aragonite fans (Corsetti and Kaufman, 2003; Pruss et al., 2008; Loyd et al.,

664 2013; see also Greene et al., 2012 for a Phanerozoic analogue), oolite (Corsetti and Kaufman, 2003; Bergmann, 2013), and hummocky cross-stratification (Le Guerroué et al., 2006a; 2006b; Melezhik et al., 2009; Husson et al., 2012) with strong ${ }^{13}$ C-depletion in the Shuram-equivalent intervals worldwide further support our view of a very shallow (probably near sediment-water interface) SMTZ during the Shuram Excursion. within individual basins have been reported from the Johnnie Formation in Death Valley (Bergmann et al., 2011), the Gametrail Formation in NW Canada (Macdonald et al., 2013), and

672 the Doushantuo Formation in South China (Jiang et al., 2007; Jiang et al., 2008; Lu et al., 2013;

673 Cui et al., 2015; Wang et al., 2016). The development of basin-scale unconformities (Lu et al.,

674 2013; Wang et al., 2016) or mixture of various proportions of authigenic carbonates (Macdonald

675 et al., 2013) have been proposed to explain such intra-basinal heterogeneity in $\delta^{13} \mathrm{C}$ expression.

676 Observational evidence for methane-derived authigenesis stratigraphically associated with the

677 Shuram Excursion, however, is currently only limited to the upper Doushantuo Formation at the 678 outer-shelf sections in South China (Ader et al., 2009; Macouin et al., 2012; Cui et al., 2016c;

679 Furuyama et al., 2016 and this study), and perhaps also the Mara Member in the Nama Group of 680 southern Namibia (Kaufman et al., 2015). An active search for these authigenic phases in the 681 fully-expressed Shuram Excursion worldwide may help to further test our hypothesis (Canfield 682 and Kump, 2013).

\subsubsection{Beyond the Shuram Excursion}


687 Hoffman et al., 1998; Halverson et al., 2005; Lang et al., 2016), and at the Ediacaran-Cambrian 688 boundary (e.g., Maloof et al., 2010a; Maloof et al., 2010b; Jiang et al., 2012), may be explained by the variable admixture of early authigenic carbonates driven by fluctuations of sulfate in the ocean. It is possible that oceanic sulfate concentration was low prior to the Ediacaran Period (Kah et al., 2004; Shen et al., 2006; Kah and Bartley, 2011; Loyd et al., 2012; Crowe et al., 2014) such that methane could have been largely released directly to the ocean and atmosphere rather than being oxidized through microbial metabolism within sediments (e.g., Halverson et al., 2002;

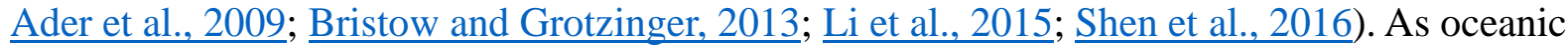
sulfate level increased in the Ediacaran Period (Fike et al., 2006; Halverson and Hurtgen, 2007; Algeo et al., 2015), however, early authigenic mineralization in shallow marine sediments was enhanced via coupled sulfate reduction and anaerobic oxidation of methane (Jørgensen and Kasten, 2006). Localized, but globally synchronous, production of ${ }^{13} \mathrm{C}$-depleted authigenic carbonate may have led to the strong negative $\delta^{13} \mathrm{C}$ excursions (e.e., Zhou et al., 2016). More detailed studies that combine petrographic, mineralogical, and fabric-specific geochemical investigations (e.g., Talbot and Kelts, 1986; Kozdon et al., 2013; Bojanowski et al., 2015; Lash, 2015; Godet et al., 2016; Śliwiński et al., 2016; Thomazo et al., 2016; Zhao et al., 2016) are needed to test these hypotheses for $\delta^{13} \mathrm{C}$ excursions throughout Earth's history.

\section{Conclusions}

Systematic sedimentological, petrographic, and chemostratigraphic investigations were conducted for the Doushantuo Formation at the outer-shelf Zhongling section in South China. Methane-derived authigenic calcite cement and nodules with extreme ${ }^{13} \mathrm{C}$-depletion $\left(\delta^{13} \mathrm{C}_{\mathrm{carb}}\right.$ down to $-37 \%$ ) were discovered, and are interpreted as direct empirical evidence of authigenesis potentially associated with the profound Shuram Excursion. Combined BSE, XRD and isotopic

711 measurements of micro-drilled samples indicate that the $\mathrm{cm}$-scale heterogeneity in $\delta^{13} \mathrm{C}_{\text {carb }}$ and

$712 \delta^{18} \mathrm{O}_{\text {carb }}$ directly reflects the relative abundance of authigenic calcite and depositional dolomite.

713 Based on integrated chemostratigraphic correlation (Cui et al., 2015), these remarkable

714 authigenic signatures at the outer shelf Zhongling section are proposed to be time-equivalent to

715 the EN3a interval of the fully-defined Shuram Excursion at the Jiulongwan section $90 \mathrm{~km}$ to the 716 north, suggesting a potential causal link between methane-derived authigenesis and the globally- 
717 expressed Shuram Excursion. In light of these novel observations (Figs. 2-10) and based on our

718 basin-scale chemostratigraphic correlation(Cui et al., 2015), we hypothesize that the Shuram

719 Excursion may be formed by localized, but globally synchronized mineralization of authigenic

720 calcite in a paleo SMTZ located near the sediment-water interface. The onset of this chemocline

721 at the water-sediment interface is believed to be a response to an increase in global seawater

722 sulfate concentrations. Our new conceptual model provides a non-actualistic interpretation for

723 the largest negative $\delta^{13} \mathrm{C}$ excursion in Earth history, and suggests a unique geochemical transition

724 in seawater during the Ediacaran Period. Our study highlights the significance of an integrated

725 approach that combines petrography, mineralogy, and texture-specific micro-drilling

726 geochemistry in chemostratigraphic studies. Such approach is suggested to be applied to fully-

727 expressed Shuram-equivalent sections (e.g., the Doushantuo Formation at Jiulongwan) in order

728 to directly test our hypothesis.

\section{Acknowledgements}

The authors want to thank Rebecca Plummer, Yongbo Peng and Mike Evans for their assistance in the UMD Paleoclimate CoLaboratory; Richard Walker, Igor Puchtel and Jingao Liu

732 for the guidance on strontium isotope analysis in the UMD TIMS lab; Peter Zavalij for the 733 assistance on XRD analysis in the UMD X-ray Crystallographic Center; Phil Piccoli, Drew

734 Muscente and Mike Meyer for their assistance on petrographic imaging in the UMD Electron

735 Probe Micro-analyzer (EPMA) Laboratory and the Virginia Tech SEM lab; and Timothy Rose

736 for the guidance on using the Cathodoluminescence Microscope and Spectrometer in the

737 Department of Mineral Sciences, Smithsonian Institution, Washington, DC. We also want to

738 thank Roberta Rudnick, James Farquhar, John Valley, Maciej Śliwiński, Chao Li, and Ganqing

739 Jiang for helpful discussion. This manuscript benefited from constructive comments by four

740 anonymous reviewers. Michael Böttcher is also acknowledged for handling this manuscript.

741 This research is funded by NASA Exobiology (NNX12AR91G to AJK and

742 NNX15AL27G to SX), NSF Sedimentary Geology and Paleontology (EAR0844270 to AJK;

743 EAR1528553 to SX), Chinese Academy of Sciences (KZZD-EW-02 to CZ), and multiple

744 graduate student research grants to HC, including the Mineralogical Society of America (MSA)

745 Grant for Student Research in Mineralogy and Petrology, the Society of Economic Geologists

746 (SEG) Student Research Grant, the Explorers Club Exploration Fund Grant, and the International 
Association of Sedimentologists (IAS) Graduate Student Research Grant. HC also wants to thank the NASA Astrobiology Institute in UW-Madison for support.

\section{Supplementary Materials}

Figure S1. Paired carbonate carbon and oxygen isotope data for micro-drilled spots in samples from the lower 200 meters of the Doushantuo Formation at the Zhongling section. Each pair of data shows $\delta^{13} \mathrm{C}_{\text {carb }}\left(\%\right.$, VPDB) and $\delta^{18} \mathrm{O}_{\text {carb }}(\%$, VPDB), respectively. Organic carbon isotope $\left(\delta^{13} \mathrm{C}_{\mathrm{org}}\right.$, VPDB) data of bulk acidified residuals are also given for each sample. Pyrite sulfur isotope $\left(\delta^{34} S_{\text {pyrite }}, C D T\right)$ data are provided for pyrite-rich samples (B and C). All scale bars are 2 $\mathrm{cm}$ long. Sample names were presented together with the sale bars. Stratigraphic height above the Marinoan (Nantuo) diamictite for each sample is provided in parentheses after each sample name. No white-colored calcite nodules are found in the lower 200 meters of this section. Some gray-colored calcite nodules are indeed found in a few carbonate samples (e.g., G, H), but they are indistinguishable from the matrix carbonate in carbon and oxygen isotope compositions.

Figure S2. X-ray powder diffraction (XRD) analysis of a fine-grained dolostone sample (12ZL49.8) from the Doushantuo Formation at the Zhongling section. The stratigraphic height for this sample is $209.2 \mathrm{~m}$.

Figure S3. Field and petrographic observations of the Shuram-equivalent EN3 interval of the Doushantuo Formation at Jiulongwan. (A) Bedded dolostone and chert bands right below the EN3a interval. (B) A closer view of the chert bands. (C) Thinly bedded limestone in the EN3b interval. (D) Large carbonate concretions in Member IV ( EN3c). (E) Needle-shaped barite crystals in the Member IV ( $\sim \mathrm{EN} 3 \mathrm{c})$. (F) Stratigraphic boundary between the EN3c black shale and the Dengying dolostone. (G-I) Thin section photomicrographs of ribbon rocks (EN3b, or upper Member III) under plane polarized light (PPL), showing micritic limestone, partial dolomitization along a stylolite, and completely dolomitized horizons, respectively. The sample names are given in the upper left of each view. Detailed information on isotopic data and stratigraphic height of each sample could be found in McFadden et al. (2008). 


\section{Figure captions}

796 Figure 1. (A) Geological map of China, with the Yangtze Craton in color. (B) Reconstructed 797 Ediacaran depositional environments on the Yangtze Craton (Jiang et al., 2011). Red dots 798 indicate the location of the Zhongling and Jiulongwan sections. (C) Simplified litho-, bio-, and 799 chrono-stratigraphy of the Ediacaran Doushantuo and Dengying formations in South China.

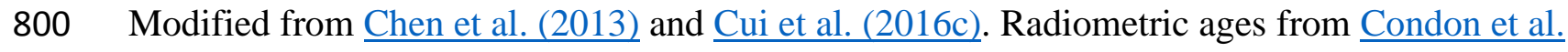
801 (2005) and Schmitz (2012). Thickness is not in scale. Cam = Cambrian; Cryo = Cryogenian. (D) 802 Reconstructed redox architecture during the deposition of the upper Doushantuo Formation. 803 Sedimentology (Jiang et al., 2011; Zhu et al., 2013) and chemostratigraphy (Cui et al., 2015; 804 Wang et al., 2016) suggest that the Doushantuo Formation at Jiulongwan section was deposited 805 in an intra-shelf environment, while the Zhongling section were deposited in an outer-shelf 806 environment. The euxinic conditions on the platform were largely restricted in intra-shelf 
807 lagoonal settings (Cui et al., 2015), rather than an open shelf environment (Li et al., 2010).

808 Sections with phosphorite deposits (e.g., inner shelf sections at Baokang, Zhangcunping, and

809 Xiaofenghe; outer shelf sections at Zhongling, Yangjiaping and Weng'an) and without

810 phosphorite deposits (e.g., intra-shelf section at Jiulongwan and slope section at Siduping,

811 Taoying, and Minle) are marked in different symbols for reference. Modified from Cui et al.

812 (2016c).

814 Figure 2. Sedimentological observation of the Doushantuo Formation at the outer-shelf

815 Zhongling section, South China. The numbers in the lower right represent stratigraphic heights in

816 the Doushantuo Formation above the Marinoan (Nantuo) diamictite. Scales are circled in each

817 view. (A) Bedded limestones of the middle Doushantuo Formation (rock hammer for scale). (B)

818 A closer view of marked area in A. (C) Medium bedded limestone and overlying mudstone. (D)

819 Thin bedded black limestone and overlying mudstone. (E, F) Grainy phosphorite interval. (G, H)

820 Stream exposure reveals interbedded calcitic and dolomitic layers with abundant white calcite

821 nodules along sedimentary bedding. Late-stage calcite veins are also visible in this view, but are

822 mostly irregularly distributed and cross cut bedding plane (pencil for scale). (I) Massive white-

823 colored calcite nodules surrounded by silica within a phosphorite horizon. (J) Lens-shaped

824 authigenic calcite interbedded with the lower Dengying dolostone.

826 Figure 3. Petrographic images of the Doushantuo Formation at the Zhongling section, showing

827 the main feathers of carbonate matrix in the studied samples. Numbers (e.g., $3.3 \mathrm{~m}$ ) below

828 sample names in the upper right represent the stratigraphic height above the Marinoan (Nantuo)

829 diamictite at the Zhongling section. PPL = plane polarized light; XPL = cross polarized light. (A,

830 B) Homogenous micritic limestone and fine-grained dolostone, respectively. (C) Phosphorite

831 intraclasts cemented by calcite. (D) Silicified phosphorite under XPL. Phosphorite grains are

832 preferentially silicified. (E) Dolomitic ooids cemented by white calcite. (F) Sparry calcite

833 cement in the dolomitic oolite. (G) Mixed dolomicrite (dark) and calcite (white or red, stained by

834 Alizarin-red S) in a limestone layer of a dolostone sample. (H, I) Disseminated pyrite in

835 phosphorite under reflective light (RL).

837 Figure 4. Petrographic observation of samples from the Doushantuo Formation at the Zhongling 
838

839

840

841

842

843

844

845

846

847

848

849

850

851

852

853

854

855

856

857

858

859

860

861

862

863

864

865

866

867

868

section, showing the main feathers of authigenic calcite in the studied samples. Numbers below sample names in the upper right represent the stratigraphic height above the Marinoan (Nantuo) diamictite at the Zhongling section. PPL $=$ plane polarized light XPL $=$ cross polarized light. (A-C) Petrographic images showing void-filling calcite cements surrounded by quartz in an intraclastic dolostone sample. Quartz crystals in the silica rim grow centripetally towards the calcite void-filling cements, suggesting that they formed before or simultaneously with the calcite. Calcite phase in this sample has ${ }^{87} \mathrm{Sr} /{ }^{86} \mathrm{Sr}$ value of 0.70811 , whereas dolomite intraclast in this sample has slightly higher ${ }^{87} \mathrm{Sr} /{ }^{86} \mathrm{Sr}$ value of 0.70879 . (D-H) Petrographic images showing void-filling calcite cements co-occurring with quartz in a dolomitic phosphorite sample. Some quartz crystals are replaced by calcite in later-stage diagenesis. Quzatz crystals in the silica rim grow centripetally towards the calcite void-filling cements, suggesting that they formed before or simultaneously with the calcite. Calcite phase in this sample $(14 \mathrm{ZL}-4.5)$ has ${ }^{87} \mathrm{Sr} /{ }^{86} \mathrm{Sr}$ value of 0.70827. Images $\mathrm{G}$ and $\mathrm{H}$ show the same view under PPL and XPL, respectively. (I)

Cathodoluminescence (CL) image of calcite and quartz in a calcite nodule. Both show dim color under CL light.

Figure 5. Paired carbonate carbon and oxygen isotope data for micro-drilled spots in samples from the first stratigraphic interval of authigenic calcite in the Doushantuo Formation at the Zhongling section. See Fig. 8J for the stratigraphic position of the three intervals of authigenic calcite. Each pair of data shows $\delta^{13} \mathrm{C}_{\text {carb }}\left(\%\right.$, VPDB) and $\delta^{18} \mathrm{O}_{\text {carb }}(\%$, VPDB), respectively. Organic carbon isotope $\left(\delta^{13} \mathrm{C}_{\mathrm{org}}\right.$, VPDB) data of bulk acidified residuals are also given for each sample. All scale bars are $2 \mathrm{~cm}$ long. Sample names were provided together with the sale bars. Stratigraphic height above the Marinoan (Nantuo) diamictite for each sample is provided in parentheses after each sample name. Yellow, white, and blue labels represent authigenic calcite phase, depositional phase, and late-stage veins, respectively. ${ }^{87} \mathrm{Sr} /{ }^{86} \mathrm{Sr}$ values are also shown for selected spots and samples when available.

Figure 6. Paired carbonate carbon and oxygen isotope data for micro-drilled spots in samples from the second stratigraphic interval of authigenic calcite in the Doushantuo Formation at the Zhongling section. See Fig. 8J for the stratigraphic position of the three intervals of authigenic calcite. Each pair of data shows $\delta^{13} \mathrm{C}_{\text {carb }}(\%, \mathrm{VPDB})$ and $\delta^{18} \mathrm{O}_{\text {carb }}(\%$, VPDB), respectively. 
869 Organic carbon isotope $\left(\delta^{13} \mathrm{C}_{\mathrm{org}}\right.$, VPDB) data of bulk acidified residuals are also given for each 870 sample. All scale bars are $2 \mathrm{~cm}$ long. Sample names were presented together with the sale bars.

871 Stratigraphic height above the Marinoan (Nantuo) diamictite for each sample is provided in

872 parentheses after each sample name. Yellow, white, and blue labels represent authigenic calcite

873 phase, depositional phase, and late-stage veins, respectively. ${ }^{87} \mathrm{Sr} /{ }^{86} \mathrm{Sr}$ values are also shown for 874 selected spots and samples when available.

876 Figure 7. Paired carbonate carbon and oxygen isotope data for micro-drilled spots in samples 877 from the third stratigraphic interval of authigenic calcite in the Doushantuo Formation at the 878 Zhongling section. See Fig. 8J for the stratigraphic position of the three intervals of authigenic 879 calcite. Each pair of data shows $\delta^{13} \mathrm{C}_{\text {carb }}\left(\%\right.$, VPDB) and $\delta^{18} \mathrm{O}_{\text {carb }}(\%$, VPDB), respectively. 880 Organic carbon isotope $\left(\delta^{13} \mathrm{C}_{\mathrm{org}}, \mathrm{VPDB}\right)$ data of bulk acidified residuals are also given for each 881 sample. All scale bars are $2 \mathrm{~cm}$ long. Sample names were presented together with the sale bars. 882 Stratigraphic height above the Marinoan (Nantuo) diamictite for each sample is provided in 883 parentheses after each sample name. Yellow, white, and blue labels represent authigenic calcite 884 phase, depositional phase, and late-stage veins, respectively. ${ }^{87} \mathrm{Sr} /{ }^{86} \mathrm{Sr}$ values are also shown for 885 selected spots and samples when available.

887 Figure 8. Litho- and chemostratigraphic profiles for the Doushantuo Formation at the intra-shelf 888 Jiulongwan section (A-I) and the outer-shelf Zhongling section $(\mathbf{J}-\mathbf{R})$. Texture- or phaseresolved geochemical data from micro-drilled spots are shown as different symbols. Cross plots of $\delta^{13} \mathrm{C}_{\text {carb }}\left(\%\right.$, VPDB) vs $\delta^{18} \mathrm{O}_{\text {carb }}(\%$, VPDB) are shown in $\mathbf{I}$ and $\mathbf{R}$ for the Jiulongwan section and the Zhongling section, respectively. The three intervals of authigenic calcite are identified in the upper 60 meters of the Doushantuo Formation at the Zhongling section. Each interval is associated with a distinct phosphorite interval, suggesting potential linkage between authigenic carbonates and phosphorus cycle (Cui et al., 2016c). The third interval has been proposed to be correlative with the EN3a interval of the intra-shelf Jiulongwan section (Cui et al., 2015). Chemostratigraphic data of the Jiulongwan section are from Jiang et al. (2007); McFadden et al. (2008), and Sawaki et al. (2010). $\delta^{13} \mathrm{C}_{\text {carb }}$ and $\delta^{18} \mathrm{O}_{\text {carb }}$ data in authigenic phase of the Zhongling section are new, with $\delta^{34} \mathrm{~S}_{\text {pyrite }}, \delta^{13} \mathrm{C}_{\text {org }}$ and ${ }^{87} \mathrm{Sr} /{ }^{86} \mathrm{Sr}$ data published in Cui et al. (2015). A complete dataset for the Zhongling section is included in the online supplementary material. 
901 Figure 9. Backscattered electron (BSE) images and quantitative X-ray powder diffraction (XRD) 902 of a fine-grained dolostone sample (12ZL-49.8) from the Doushantuo Formation at the 903 Zhongling section. The stratigraphic height for this sample is $209.2 \mathrm{~m}$. (A) $\delta^{13} \mathrm{C}_{\text {carb }}$ (\%o, VPDB) 904 and $\delta^{18} \mathrm{O}_{\text {carb }}(\%$, VPDB) values are shown for ten micro-drilled layers, including a small 905 authigenic calcite nodule at the bottom. ${ }^{87} \mathrm{Sr} /{ }^{86} \mathrm{Sr}$ data are also shown when available. ${ }^{87} \mathrm{Sr} /{ }^{86} \mathrm{Sr}$ 906 composition of dolomicrite-rich layer is slightly higher than calcite-dominated spots. (B, C) BSE 907 images reveals that carbonate layer with positive $\delta^{13} \mathrm{C}_{\text {carb }}$ is dolomicrite rich, while carbonate 908 layer with negative $\delta^{13} \mathrm{C}_{\text {carb }}$ is calcite rich. Dolomite in dark color, whereas calcite in light color. 909 (D, E) Mg elemental maps of two micro-drilled samples marked as [2] and [3] in A, showing a 910 dolomite-dominated layer and a mixed dolomicrite-calcite layer, respectively. Calcite in dark 911 black color, whereas dolomite in bright green color. (F, G) Cross plots of isotopic compositions 912 and mineralogical proportions (determined from quantitative XRD analysis) of the ten micro913 drilled samples showing a mixing line between a dolomicrite end member and an authigenic 914 calcite end member. $(\mathbf{H}, \mathbf{I})$ Cross plots between isotope and mineralogical compositions, showing 915 that the degree of ${ }^{13} \mathrm{C}$ and ${ }^{18} \mathrm{O}$ depletion values is directly correlated to the percentage of 916 authigenic calcite in each micro-sample. All data can be found in the online supplementary 917 material.

919 Figure 10. Carbonate $\delta^{13} \mathrm{C}-\delta^{18} \mathrm{O}$ cross plots for different horizons in the upper 60 meters of the 920 Doushantuo Formation at the Zhongling section. Stratigraphically nearby samples are combined 921 for the $\delta^{13} \mathrm{C}-\delta^{18} \mathrm{O}$ cross plots. (A) $\delta^{13} \mathrm{C}-\delta^{18} \mathrm{O}$ cross plots of oolitic dolostone with authigenic 922 calcite cement at the stratigraphic height of $\sim 240 \mathrm{~m}$. Plotted data are measured from 923 samples12ZL-19,14ZL-19, 14ZL-19.5 and 14ZL-20; (B) $\delta^{13} \mathrm{C}-\delta^{18} \mathrm{O}$ cross plots of intraclastic 924 dolostone with authigenic calcite cement at the stratigraphic height of $237.4 \mathrm{~m}$. Plotted data are 925 measured from sample 12ZL-21.6; (C) $\delta^{13} \mathrm{C}-\delta^{18} \mathrm{O}$ cross plots of interbedded dolomicrite layer 926 and calcite layer at the stratigraphic height of $\sim 210 \mathrm{~m}$. Plotted data are measured from samples 927 14ZL-49,14ZL-49.2, 14ZL-49.8 and 12ZL-49.8; (D) $\delta^{13} \mathrm{C}-\delta^{18} \mathrm{O}$ cross plots of interbedded 928 dolomicrite layer and calcite layer at the stratigraphic height of $\sim 205 \mathrm{~m}$. Plotted data are 929 measured from samples 14ZL-53.5,14ZL-54, 14ZL-54.3 and14ZL-55. 
931 Figure 11. Solubility of amorphous silica (left y-axis) and calcite (right y-axis) as a function of $932 \mathrm{pH}$, modified from figures 6.6 and 7.7 of Langmuir et al. (1997) and Figure S1 of Xiao et al. 933 (2010). Calcite solubility calculated at $25^{\circ} \mathrm{C}$ and 1 bar total pressure with an assumed $\mathrm{P}_{\mathrm{CO} 2}=$ $93410^{-3.5}$ bar. The growth of authigenic calcite and quartz rim could be described as a two-stage 935 process in response to changes in $\mathrm{pH}$. Stage 1 is characterized by the dissolution of pre-existing 936 host carbonate and authigenic mineralization of quartz. Stage 2 is characterized by authigenic 937 mineralization of calcite and partial replacement of quartz by calcite. See the main text for full 938 discussion.

Figure 12. Progressive deepening of a sulfate-methane transition zone (SMTZ) driven by 941 increasing seawater sulfate concentrations. (A) A scenario lacking a SMTZ due to the extremely 942 low sulfate concentration in seawater for most of the Precambrian time. In this scenario, biogenic 943 methane flux may have largely escaped out of the sediments into the water column and the

944 atmosphere. (B) Based on the novel observation of authigenic calcite in this study, we propose 945 that the SMTZ may be placed near the sediment-water interface in response to an increase in 946 seawater sulfate concentration. (C) With the emergence of bioturbation and further increase in 947 seawater sulfate concentration, the SMTZ in modern marine environments is driven deeper into 948 the sediments. The evolution of the SMTZ is proposed to be closely linked to the seawater 949 sulfate concentration through the Earth's history. The sulfate concentration was ca. $200 \mu \mathrm{M}$ or 950 less before $2.4 \mathrm{Ga}$ (Habicht et al., 2002; Zhelezinskaia et al., 2014). After this, concentrations 951 rose to values probably not exceeding 1 to $2 \mathrm{mM}$ over the next 1.6 billion years or so (Yellow 952 star 1 in A) (Canfield and Farquhar, 2009). Based on the observation of modern marine 953 sediments, anaerobic oxidation of methane (AOM) within SMTZ requires sulfate concentration 954 in pore water to be $<10 \mathrm{mM}$ (Yellow star 2 in C) (Jørgensen and Kasten, 2006). Projecting this 955 threshold to the scenario B, the formation of authigenic carbonates within a seafloor SMTZ 956 requires seawater sulfate to be no more than ca. $10 \mathrm{mM}$ (Yellow star 2 in B). The sulfate 957 concentration in the modern ocean is ca. $28 \mathrm{mM}$ (Yellow star 3 in $\mathbf{C}$ ).

959 Figure 13. Different models for the interpretation of tight $\delta^{13} \mathrm{C}_{\text {carb }}-\delta^{18} \mathrm{O}_{\text {carb }}$ correlation in the late 960 Precambrian carbonate strata. (A) $\delta^{13} \mathrm{C}_{\text {carb }}$ and $\delta^{18} \mathrm{O}_{\text {carb }}$ model proposed by Jacobsen and 961 Kaufman (1999). This model defines a hyperbolic curve with increasing fluid-rock interaction. 
$962 \delta^{18} \mathrm{O}_{\text {carb }}$ is more prone to diagenetic overprint compared with $\delta^{13} \mathrm{C}_{\text {carb }}$. (B) Meteoric alteration 963 model proposed by Knauth and Kennedy (2009). Based on this mode, assuming the existence of 964 considerable terrestrial biomass, Knauth and Kennedy (2009) proposed a global greening event 965 during late Precambrian. (C) Burial diagenesis model proposed by Derry (2010a). Based on this

966 mode, Derry (2010a) argued that the global Shuram Excursion results from burial diagenesis, and 967 thus is lack of paleoclimatic significance. (D) Authigenic mixing model proposed in this study.

968 Based on novel data revealed in this study, we propose that the tight $\delta^{13} \mathrm{C}_{\text {carb }}-\delta^{18} \mathrm{O}_{\text {carb }}$ correlation 969 in the uppermost Doushantuo Formation, and potentially also in the global Shuram Excursion, 970 results from progressive authigenic mineralization of primary marine carbonates during very

971 early diagenesis. Late diagenesis during deep burial may have led the overall $\delta^{18} \mathrm{O}_{\text {carb }}$

972 compositions to more negative values. See the main text for detailed discussion. $\mathrm{AOM}=$

973 Anaerobic Oxidation of Methane.

975 Figure 14. Geochemical and petrographic data of the upper Doushantuo Formation at the 976 Jiulongwan section. Litho- and chemostratigraphic profiles (A-G) and cross plots (H-L) of the 977 EN3 interval, widely interpreted as equivalent to the Shuram excursion. Barium concentrations $978[\mathrm{Ba}]$ are new data from this study. Other data are from Zhou et al. (2012). Petrographic studies suggest that samples with high $\mathrm{Mg} / \mathrm{Ca}$ and $\mathrm{Mn} / \mathrm{Sr}$ ratios are altered by late dolomitization. In spite of dolomitization of a few samples, the EN3 interval reveals a clear increase in [Sr], [Ba],

${ }^{87} \mathrm{Sr} /{ }^{86} \mathrm{Sr}$, and $\mathrm{Ce} / \mathrm{Ce} *$, suggesting the confluence of enhanced chemical weathering, ocean anoxia, authigenic barite mineralization, and anaerobic oxidation of methane at the SMTZ. All the elemental concentration data plotted in this figure are dissolved by $0.5 \mathrm{~N}$ acetic acid. The complete data set can be found in the online supplementary material. Please refer to the supplementary material for detailed field and petrographic observations. multilayered water column in the Ediacaran Yangtze platform? Insights from carbonate and organic matter paired $\delta^{13} \mathrm{C}$. Earth and Planetary Science Letters, 288, 213-227.

991 Adkins, J.F., McIntyre, K., Schrag, D.P., 2002. The salinity, temperature, and $\delta^{18} \mathrm{O}$ of the glacial 992 deep ocean. Science, 298, 1769-1773. 
Aharon, P., Schwarcz, H.P., Roberts, H.H., 1997. Radiometric dating of submarine hydrocarbon seeps in the Gulf of Mexico. Geological Society of America Bulletin, 109, 568-579.

Ahr, W.M., 2011. Geology of Carbonate Reservoirs: The identification, description and characterization of hydrocarbon reservoirs in carbonate rocks. John Wiley \& Sons.

Algeo, T.J., Luo, G.M., Song, H.Y., Lyons, T.W., Canfield, D.E., 2015. Reconstruction of secular variation in seawater sulfate concentrations. Biogeosciences, 12, 2131-2151.

Arthur, M.A., 2009. Carbonate rocks deconstructed. Nature, 460, 698-699.

Banner, J.L., Hanson, G.N., 1990. Calculation of simultaneous isotopic and trace element variations during water-rock interaction with applications to carbonate diagenesis. Geochimica et Cosmochimica Acta, 54, 3123-3137.

Bergmann, K.D., Zentmyer, R.A., Fischer, W.W., 2011. The stratigraphic expression of a large negative carbon isotope excursion from the Ediacaran Johnnie Formation, Death Valley. Precambrian Research, 188, 45-56.

Bergmann, K.D., 2013. Constraints on the carbon cycle and climate during the early evolution of animals, California Institute of Technology, Pasadena, California.

Berner, R.A., 1971. Principles of Chemical Sedimentology. McGraw-Hill, New York.

Berner, R.A., 1981. Authigenic mineral formation resulting from organic matter decomposition in modern sediments. Fortschritte der mineralogie, 59, 117-135.

Birnbaum, S.J., Wireman, J.W., 1984. Bacterial sulfate reduction and pH: implications for early diagenesis. Chemical Geology, 43, 143-149.

Bishop, J.W., Osleger, D.A., Montañez, I.P., Sumner, D.Y., 2014. Meteoric diagenesis and fluidrock interaction in the Middle Permian Capitan backreef: Yates Formation, Slaughter Canyon, New Mexico. AAPG Bulletin, 98, 1495-1519.

Bjerrum, C.J., Canfield, D.E., 2011. Towards a quantitative understanding of the late Neoproterozoic carbon cycle. Proceedings of the National Academy of Sciences, 108, 55425547.

Bojanowski, M.J., Bagiński, B., Guillermier, C., Franchi, I.A., 2015. Carbon and oxygen isotope analysis of hydrate-associated Oligocene authigenic carbonates using NanoSIMS and IRMS. Chemical Geology, 416, 51-64.

Borowski, W.S., Paull, C.K., Ussler, W., 1996. Marine pore-water sulfate profiles indicate in situ methane flux from underlying gas hydrate. Geology, 24, 655-658.

Borowski, W.S., Paull, C.K., Ussler Iii, W., 1999. Global and local variations of interstitial sulfate gradients in deep-water, continental margin sediments: Sensitivity to underlying methane and gas hydrates. Marine Geology, 159, 131-154. 
Bottjer, D.J., Hagadorn, J.W., Dornbos, S.Q., 2000. The Cambrian substrate revolution. GSA today, 10, 1-7.

Bristow, T.F., Bonifacie, M., Derkowski, A., Eiler, J.M., Grotzinger, J.P., 2011. A hydrothermal origin for isotopically anomalous cap dolostone cements from south China. Nature, 474, 68-71.

Bristow, T.F., Grotzinger, J.P., 2013. Sulfate availability and the geological record of cold-seep deposits. Geology, 41, 811-814.

Burns, S.J., Matter, A., 1993. Carbon isotopic record of the latest Proterozoic from Oman. Eclogae Geologicae Helvetiae, 86, 595-607.

Burns, S.J., Haudenschild, U., Matter, A., 1994. The strontium isotopic composition of carbonates from the late Precambrian ( $\sim 560-540 \mathrm{Ma})$ Huqf Group of Oman. Chemical Geology, 111, 269-282.

Butterfield, N.J., 2009. Oxygen, animals and oceanic ventilation: an alternative view. Geobiology, $7,1-7$.

Butterfield, N.J., 2011. Animals and the invention of the Phanerozoic Earth system. Trends in Ecology \& Evolution, 26, 81-87.

Calver, C.R., 2000. Isotope stratigraphy of the Ediacarian (Neoproterozoic III) of the Adelaide Rift Complex, Australia, and the overprint of water column stratification. Precambrian Research, 100, 121-150.

Campbell, K.A., 2006. Hydrocarbon seep and hydrothermal vent paleoenvironments and paleontology: Past developments and future research directions. Palaeogeography, Palaeoclimatology, Palaeoecology, 232, 362-407.

Canfield, D.E., Poulton, S.W., Knoll, A.H., Narbonne, G.M., Ross, G., Goldberg, T., Strauss, H., 2008. Ferruginous conditions dominated later Neoproterozoic deep-water chemistry. Science, 321, 949-952.

Canfield, D.E., Farquhar, J., 2009. Animal evolution, bioturbation, and the sulfate concentration of the oceans. Proceedings of the National Academy of Sciences, 106, 8123-8127.

Canfield, D.E., Kump, L.R., 2013. Carbon cycle makeover. Science, 339, 533-534.

Carbone, C., Narbonne, G.M., 2014. When life got smart: The evolution of behavioral complexity through the Ediacaran and early Cambrian of NW Canada. Journal of Paleontology, 88, 309-330.

Catling, D.C., Claire, M.W., Zahnle, K.J., 2007. Anaerobic methanotrophy and the rise of atmospheric oxygen. Philosophical Transactions of the Royal Society A: Mathematical, Physical and Engineering Sciences, 365, 1867-1888.

Chen, X., Ling, H.-F., Vance, D., Shields-Zhou, G.A., Zhu, M., Poulton, S.W., Och, L.M., Jiang, 
S.-Y., Li, D., Cremonese, L., Archer, C., 2015. Rise to modern levels of ocean oxygenation coincided with the Cambrian radiation of animals. Nature Communications, 6, 7142.

Chen, Z., Zhou, C., Meyer, M., Xiang, K., Schiffbauer, J.D., Yuan, X., Xiao, S., 2013. Trace fossil evidence for Ediacaran bilaterian animals with complex behaviors. Precambrian Research, 224, 690-701.

Coleman, M.L., Raiswell, R., 1995. Source of carbonate and origin of zonation in pyritiferous carbonate concretions; evaluation of a dynamic model. American Journal of Science, 295, 282308.

Condon, D., Zhu, M., Bowring, S., Wang, W., Yang, A., Jin, Y., 2005. U-Pb ages from the neoproterozoic Doushantuo Formation, China. Science, 308, 95-98.

Corsetti, F.A., Kaufman, A.J., 2003. Stratigraphic investigations of carbon isotope anomalies and Neoproterozoic ice ages in Death Valley, California. Geological Society of America Bulletin, 115, 916-932.

Crowe, S.A., Paris, G., Katsev, S., Jones, C., Kim, S.-T., Zerkle, A.L., Nomosatryo, S., Fowle, D.A., Adkins, J.F., Sessions, A.L., 2014. Sulfate was a trace constituent of Archean seawater. Science, 346, 735-739.

Cui, H., 2015. Authigenesis, biomineralization, and carbon-sulfur cycling in the Ediacaran ocean (Ph.D. dissertation), University of Maryland, College Park.

Cui, H., Kaufman, A.J., Xiao, S., Zhu, M., Zhou, C., Liu, X.-M., 2015. Redox architecture of an Ediacaran ocean margin: Integrated chemostratigraphic $\left(\delta^{13} \mathrm{C}-\delta^{34} \mathrm{~S}-{ }^{87} \mathrm{Sr} /{ }^{86} \mathrm{Sr}-\mathrm{Ce} / \mathrm{Ce} *\right)$ correlation of the Doushantuo Formation, South China. Chemical Geology, 405, 48-62.

Cui, H., Grazhdankin, D.V., Xiao, S., Peek, S., Rogov, V.I., Bykova, N.V., Sievers, N.E., Liu, X.M., Kaufman, A.J., 2016a. Redox-dependent distribution of early macro-organisms: Evidence from the terminal Ediacaran Khatyspyt Formation in Arctic Siberia. Palaeogeography, Palaeoclimatology, Palaeoecology, 461, 122-139.

Cui, H., Kaufman, A.J., Xiao, S., Peek, S., Cao, H., Min, X., Cai, Y., Siegel, Z., Liu, X.M., Peng, Y., Schiffbauer, J.D., Martin, A.J., 2016b. Environmental context for the terminal Ediacaran biomineralization of animals. Geobiology, 14, 344-363.

Cui, H., Xiao, S., Zhou, C., Peng, Y., Kaufman, A.J., Plummer, R.E., 2016c. Phosphogenesis associated with the Shuram Excursion: Petrographic and geochemical observations from the Ediacaran Doushantuo Formation of South China. Sedimentary Geology, 341, 134-146.

Davidson, D.W., Leaist, D.G., Hesse, R., 1983. Oxygen-18 enrichment in the water of a clathrate hydrate. Geochimica et Cosmochimica Acta, 47, 2293-2295.

Degens, E.T., Epstein, S., 1964. Oxygen and carbon isotope ratios in coexisting calcites and dolomites from recent and ancient sediments. Geochimica et Cosmochimica Acta, 28, 23-44. 
Derkowski, A., Bristow, T.F., Wampler, J.M., Środoń, J., Marynowski, L., Elliott, W.C., Chamberlain, C.P., 2013. Hydrothermal alteration of the Ediacaran Doushantuo Formation in the Yangtze Gorges area (South China). Geochimica et Cosmochimica Acta, 107, 279-298.

Derry, L.A., 2010a. A burial diagenesis origin for the Ediacaran Shuram-Wonoka carbon isotope anomaly. Earth and Planetary Science Letters, 294, 152-162.

Derry, L.A., 2010b. On the significance of $\delta^{13} \mathrm{C}$ correlations in ancient sediments. Earth and Planetary Science Letters, 296, 497-501.

Dickens, G.R., 2001. Sulfate profiles and barium fronts in sediment on the Blake Ridge: present and past methane fluxes through a large gas hydrate reservoir. Geochimica et Cosmochimica Acta, 65, 529-543.

Dickens, G.R., Fewless, T., Thomas, E., Bralower, T.J., 2003. Excess barite accumulation during the Paleocene-Eocene Thermal Maximum: Massive input of dissolved barium from seafloor gas hydrate reservoirs. Geological Society of America Special Paper, 369, 11-24.

Evans, M., Selmer, K., Breeden, B., Lopatka, A., Plummer, R., 2016. Correction algorithm for on-line continuous flow $\delta^{13} \mathrm{C}$ and $\delta^{18} \mathrm{O}$ carbonate and cellulose stable isotope analyses. Geochemistry, Geophysics, Geosystems, 17, 3580-3588.

Feng, D., Roberts, H.H., 2011. Geochemical characteristics of the barite deposits at cold seeps from the northern Gulf of Mexico continental slope. Earth and Planetary Science Letters, 309, 89-99.

Fike, D.A., Grotzinger, J.P., Pratt, L.M., Summons, R.E., 2006. Oxidation of the Ediacaran ocean. Nature, 444, 744-747.

Furuyama, S., Kano, A., Kunimitsu, Y., Ishikawa, T., Wei, W., 2016. Diagenetic overprint to a negative carbon isotope anomaly associated with the Gaskiers glaciation of the Ediacaran Doushantuo Formation in South China. Precambrian Research, 110-122.

Gilleaudeau, G.J., Kah, L.C., 2013. Carbon isotope records in a Mesoproterozoic epicratonic sea: Carbon cycling in a low-oxygen world. Precambrian Research, 228, 85-101.

Glenn, C.R., Föllmi, K.B., Riggs, S.R., Baturin, G.N., Grimm, K.A., Trappe, J., Abed, A.M., Galli-Oliver, C., Garrison, R.E., Ilyan, A., Jehl, C., Rohrlich, V., Sadaqah, R.M., Schidlowski, M., Sheldon, R.E., Siegmund, H., 1994. Phosphorus and phosphorites: Sedimentology and environments of formation. Eclogae Geologicae Helvetiae, 87, 747-788.

Glenn, C.R., Prévôt-Lucas, L., Lucas, J., 2000. Marine Authigenesis: From Global To Microbial. SEPM Special Publication No. 66. SEPM (Society for Sedimentary Geology), Tullsa, Oklahoma, USA.

Godet, A., Durlet, C., Spangenberg, J.E., Föllmi, K.B., 2016. Estimating the impact of early diagenesis on isotope records in shallow-marine carbonates: A case study from the Urgonian Platform in western Swiss Jura. Palaeogeography, Palaeoclimatology, Palaeoecology, 454, 125- 
138.

1133 Gomez, F.J., Kah, L.C., Bartley, J.K., Astini, R.A., 2014. Microbialites in a high-altitude Andean 1134 lake: multiple controls in carbonate precipitation and lamina accretion. Palaios, 29, 233-249.

1135 Greene, S.E., Bottjer, D.J., Corsetti, F.A., Berelson, W.M., Zonneveld, J.-P., 2012. A subseafloor carbonate factory across the Triassic-Jurassic transition. Geology, 40, 1043-1046.

1137 Greinert, J., Bohrmann, G., Suess, E., 2001. Gas hydrate-associated carbonates and methaneventing at Hydrate Ridge: Classification, distribution, and origin of authigenic lithologies. In: Paull, C.K., Dillon, W.P. (Eds.), Natural Gas Hydrates: Occurrence, Distribution, and Detection. American Geophysical Union, Washington, D. C., pp. 99-113.

Gross, M.G., Tracey, J.I., 1966. Oxygen and carbon isotopic composition of limestones and dolomites, Bikini and Eniwetok Atolls. Science, 151, 1082-1084.

1143 Grotzinger, J.P., Fike, D.A., Fischer, W.W., 2011. Enigmatic origin of the largest-known carbon isotope excursion in Earth's history. Nature Geoscience, 4, 285-292.

1145 Habicht, K.S., Gade, M., Thamdrup, B., Berg, P., Canfield, D.E., 2002. Calibration of sulfate 1146 levels in the Archean ocean. Science, 298, 2372-2374.

1147 Haeckel, M., Suess, E., Wallmann, K., Rickert, D., 2004. Rising methane gas bubbles form massive hydrate layers at the seafloor. Geochimica et Cosmochimica Acta, 68, 4335-4345. Elliott, D., Cui, H., Fedonkin, M., Hoffmann, K.-H., Wilson, S.A., Schneider, G., Smith, J., 2013. Stratigraphy, palaeontology and geochemistry of the late Neoproterozoic Aar Member, southwest Namibia: Reflecting environmental controls on Ediacara fossil preservation during the terminal Proterozoic in African Gondwana. Precambrian Research, 238, 214-232. carbon cycle before the Ghaub glaciation (Neoproterozoic) in Namibia: Prelude to snowball Earth? Geochemistry, Geophysics, Geosystems, 3, 1-24.

1157 Halverson, G.P., Hoffman, P.F., Schrag, D.P., Maloof, A.C., Rice, A.H.N., 2005. Toward a Neoproterozoic composite carbon-isotope record. Geological Society of America Bulletin, 117, 1159 1181-1207.

1160 Halverson, G.P., Hurtgen, M.T., 2007. Ediacaran growth of the marine sulfate reservoir. Earth 1161 and Planetary Science Letters, 263, 32-44.

1162 Hayes, J.M., 1994. Global methanotrophy at the Archean-Proterozoic transition. In: Bengtson, S. 220-236.

1165 Hayes, J.M., Waldbauer, J.R., 2006. The carbon cycle and associated redox processes through 1166 time. Philosophical Transactions of the Royal Society B: Biological Sciences, 361, 931-950. 
Higgins, J., Fischer, W., Schrag, D., 2009. Oxygenation of the ocean and sediments: consequences for the seafloor carbonate factory. Earth and Planetary Science Letters, 284, 25-33.

1169 Hoffman, P.F., Kaufman, A.J., Halverson, G.P., Schrag, D.P., 1998. A Neoproterozoic Snowball Earth. Science, 281, 1342-1346.

1171 Hohl, S., Becker, H., Herzlieb, S., Guo, Q., 2015. Multiproxy constraints on alteration and 1172 primary compositions of Ediacaran deep-water carbonate rocks, Yangtze Platform, South China. 1173 Geochimica et Cosmochimica Acta, 163, 262-278.

1174 Horita, J., 2014. Oxygen and carbon isotope fractionation in the system dolomite-water- $\mathrm{CO}_{2}$ to elevated temperatures. Geochimica et Cosmochimica Acta, 129, 111-124.

1176

1177

1178

1179

1180

1181

1182

1183

1184

1185

1186

1187

1188

1189

1190

1191

1192

1193

1194

1195

1196

1197

1198

1199

1200

1201

Horton, T.W., Defliese, W.F., Tripati, A.K., Oze, C., 2015. Evaporation induced ${ }^{18} \mathrm{O}$ and ${ }^{13} \mathrm{C}$ enrichment in lake systems: A global perspective on hydrologic balance effects. Quaternary Science Reviews, 365-379.

Hovland, M., Talbot, M.R., Qvale, H., Olaussen, S., Aasberg, L., 1987. Methane-related carbonate cements in pockmarks of the North Sea. Journal of Sedimentary Research, 57, 881892.

Huang, J., Chu, X., Jiang, G., Feng, L., Chang, H., 2011. Hydrothermal origin of elevated iron, manganese and redox-sensitive trace elements in the $c$. 635 Ma Doushantuo cap carbonate. Journal of the Geological Society, 168, 805-816.

Husson, J.M., Maloof, A.C., Schoene, B., 2012. A syn-depositional age for Earth's deepest $\delta^{13}$ C excursion required by isotope conglomerate tests. Terra Nova, 24, 318-325.

Husson, J.M., Higgins, J.A., Maloof, A.C., Schoene, B., 2015a. Ca and Mg isotope constraints on the origin of Earth's deepest C excursion. Geochimica et Cosmochimica Acta, 160, 243-266.

Husson, J.M., Maloof, A.C., Schoene, B., Chen, C.Y., Higgins, J.A., 2015b. Stratigraphic expression of Earth's deepest $\delta^{13} \mathrm{C}$ excursion in the Wonoka Formation of South Australia. American Journal of Science, 315, 1-45.

Jacobsen, S.B., Kaufman, A.J., 1999. The Sr, C and O isotopic evolution of Neoproterozoic seawater. Chemical Geology, 161, 37-57.

Jaffrés, J.B., Shields, G.A., Wallmann, K., 2007. The oxygen isotope evolution of seawater: A critical review of a long-standing controversy and an improved geological water cycle model for the past 3.4 billion years. Earth-Science Reviews, 83, 83-122.

Jiang, G., Kennedy, M.J., Christie-Blick, N., 2003. Stable isotopic evidence for methane seeps in Neoproterozoic postglacial cap carbonates. Nature, 426, 822-826.

Jiang, G., Kennedy, M.J., Christie-Blick, N., Wu, H., Zhang, S., 2006a. Stratigraphy, sedimentary structures, and textures of the late Neoproterozoic Doushantuo cap carbonate in South China. Journal of Sedimentary Research, 76, 978-995. 
Jiang, G., Shi, X., Zhang, S., 2006b. Methane seeps, methane hydrate destabilization, and the late Neoproterozoic postglacial cap carbonates. Chinese Science Bulletin, 51, 1152-1173.

Jiang, G., Kaufman, A.J., Christie-Blick, N., Zhang, S., Wu, H., 2007. Carbon isotope variability across the Ediacaran Yangtze platform in South China: Implications for a large surface-to-deep ocean $\delta^{13} \mathrm{C}$ gradient. Earth and Planetary Science Letters, 261, 303-320.

Jiang, G., Zhang, S., Shi, X., Wang, X., 2008. Chemocline instability and isotope variations of the Ediacaran Doushantuo basin in South China. Science in China Series D: Earth Sciences, 51, $1560-1569$.

Jiang, G., Shi, X., Zhang, S., Wang, Y., Xiao, S., 2011. Stratigraphy and paleogeography of the Ediacaran Doushantuo Formation (ca. 635-551Ma) in South China. Gondwana Research, 19, 831-849.

Jiang, G., Wang, X., Shi, X., Xiao, S., Zhang, S., Dong, J., 2012. The origin of decoupled carbonate and organic carbon isotope signatures in the early Cambrian (ca. 542-520Ma) Yangtze platform. Earth and Planetary Science Letters, 317-318, 96-110.

Jørgensen, B.B., 1982. Mineralization of organic matter in the sea bed-the role of sulphate reduction. Nature, 296, 643-645.

Jørgensen, B.B., Kasten, S., 2006. Sulfur cycling and methane oxidation. In: Schulz, H.D., Zabel, M. (Eds.), Marine Geochemistry. Springer-Verlag Berlin Heidelberg, Berlin, pp. 271-309.

Joseph, C., Torres, M., Martin, R., Haley, B., Pohlman, J., Riedel, M., Rose, K., 2012. Using the ${ }^{87} \mathrm{Sr} /{ }^{86} \mathrm{Sr}$ of modern and paleoseep carbonates from northern Cascadia to link modern fluid flow to the past. Chemical Geology, 334, 122-130.

Kah, L.C., 2000. Depositional $\delta^{18} \mathrm{O}$ signatures in Proterozoic dolostones: constraints on seawater chemistry and early diagenesis. In: Grotzinger, J.P., James, N.P. (Eds.), Carbonale Sedimentation and Diagenesis in the Evolving Precambrian World. SEPM Society for Sedimentary Geology, Tulsa, Oklahoma, USA, pp. 245-260.

Kah, L.C., Lyons, T.W., Frank, T.D., 2004. Low marine sulphate and protracted oxygenation of the Proterozoic biosphere. Nature, 431, 834-838.

Kah, L.C., Bartley, J.K., 2011. Protracted oxygenation of the Proterozoic biosphere. International Geology Review, 53, 1424-1442.

Kasting, J.F., Howard, M.T., Wallmann, K., Veizer, J., Shields, G., Jaffrés, J., 2006. Paleoclimates, ocean depth, and the oxygen isotopic composition of seawater. Earth and Planetary Science Letters, 252, 82-93.

Kastner, M., 1999. Oceanic minerals: Their origin, nature of their environment, and significance. Proceedings of the National Academy of Sciences, 96, 3380-3387.

Kaufman, A.J., Corsetti, F.A., Varni, M.A., 2007. The effect of rising atmospheric oxygen on 
carbon and sulfur isotope anomalies in the Neoproterozoic Johnnie Formation, Death Valley, USA. Chemical Geology, 237, 47-63.

Kaufman, A.J., Kriesfeld, L., Cui, H., Narbonne, G.M., Vickers-Rich, P., Zhou, C., Xiao, S., 2015. An authigenic origin for the middle Ediacaran Shuram excursion: The view from Namibia and South China, 2015 GSA Annual Meeting in Baltimore, Maryland, USA. The Geological Society of America, Baltimore, Maryland, USA, pp. 451.

Kennedy, M., Mrofka, D., von der Borch, C., 2008. Snowball Earth termination by destabilization of equatorial permafrost methane clathrate. Nature, 453, 642-645.

Knauth, L.P., 2005. Temperature and salinity history of the Precambrian ocean: implications for the course of microbial evolution. Palaeogeography, Palaeoclimatology, Palaeoecology, 219, 5369.

Knauth, L.P., Kennedy, M.J., 2009. The late Precambrian greening of the Earth. Nature, 460, $728-732$.

Kozdon, R., Kelly, D., Kitajima, K., Strickland, A., Fournelle, J., Valley, J., 2013. In situ $\delta^{18} \mathrm{O}$ and $\mathrm{Mg} / \mathrm{Ca}$ analyses of diagenetic and planktic foraminiferal calcite preserved in a deep-sea record of the Paleocene-Eocene thermal maximum. Paleoceanography, 28, 517-528.

Kump, L.R., Arthur, M.A., 1999. Interpreting carbon-isotope excursions: carbonates and organic matter. Chemical Geology, 161, 181-198.

Lang, X., Shen, B., Peng, Y., Huang, K., Lv, J., Ma, H., 2016. Ocean oxidation during the deposition of basal Ediacaran Doushantuo cap carbonates in the Yangtze Platform, South China. Precambrian Research, 281, 253-268.

Langmuir, D., Hall, P., Drever, J., 1997. Environmental Geochemistry. Prentice Hall, New Jersey.

Lash, G.G., 2015. Authigenic barite nodules and carbonate concretions in the Upper Devonian shale succession of western New York - A record of variable methane flux during burial. Marine and Petroleum Geology, 59, 305-319.

Le Guerroué, E., 2006. Sedimentology and chemostratigraphy of the Ediacaran Shuram Formation, Nafun Group, Oman, Eidgenössische Technische Hochschule Zürich (ETHZ), Zürich, Switzerland.

Le Guerroué, E., Allen, P.A., Cozzi, A., 2006a. Parasequence development in the Ediacaran Shuram Formation (Nafun Group, Oman): high - resolution stratigraphic test for primary origin of negative carbon isotopic ratios. Basin Research, 18, 205 - 219.

Le Guerroué, E., Allen, P.A., Cozzi, A., 2006b. Chemostratigraphic and sedimentological framework of the largest negative carbon isotopic excursion in Earth history: The Neoproterozoic Shuram Formation (Nafun Group, Oman). Precambrian Research, 146, 68-92.

Le Guerroué, E., Allen, P.A., Cozzi, A., Etienne, J.L., Fanning, M., 2006c. 50 Myr recovery from 
1272 the largest negative $\delta^{13} \mathrm{C}$ excursion in the Ediacaran ocean. Terra Nova, 18, 147-153.

1273 Lee, C., Fike, D.A., Love, G.D., Sessions, A.L., Grotzinger, J.P., Summons, R.E., Fischer, W.W., 1274 2013. Carbon isotopes and lipid biomarkers from organic-rich facies of the Shuram Formation, 1275 Sultanate of Oman. Geobiology, 11, 406-419.

1276 Lee, C., Love, G.D., Fischer, W.W., Grotzinger, J.P., Halverson, G.P., 2015. Marine organic matter cycling during the Ediacaran Shuram excursion. Geology, 43, 1103-1106.

1278 Lein, A.Y., 2004. Authigenic carbonate formation in the ocean. Lithology and Mineral Resources, $127939,1-30$.

1280 Lenton, T.M., Boyle, R.A., Poulton, S.W., Shields-Zhou, G.A., Butterfield, N.J., 2014. Coevolution of eukaryotes and ocean oxygenation in the Neoproterozoic era. Nature Geoscience, 7 , 1282 257-265.

Li, C., Love, G.D., Lyons, T.W., Fike, D.A., Sessions, A.L., Chu, X., 2010. A stratified redox model for the Ediacaran ocean. Science, 328, 80-83.

1285 Li, C., Planavsky, N.J., Love, G.D., Reinhard, C.T., Hardisty, D., Feng, L., Bates, S.M., Huang, J., Zhang, Q., Chu, X., Lyons, T.W., 2015. Marine redox conditions in the middle Proterozoic ocean and isotopic constraints on authigenic carbonate formation: Insights from the Chuanlinggou Formation, Yanshan Basin, North China. Geochimica et Cosmochimica Acta, 150, 90-105.

Li, F.-B., Teng, F.-Z., Chen, J.-T., Huang, K.-J., Wang, S.-J., Lang, X.-G., Ma, H.-R., Peng, Y.-B., Shen, B., 2016. Constraining ribbon rock dolomitization by $\mathrm{Mg}$ isotopes: Implications for the 'dolomite problem'. Chemical Geology, 445, 208-220.

Li, H.C., Ku, T.L., 1997. $\delta^{13} \mathrm{C}-\delta^{18} \mathrm{C}$ covariance as a paleohydrological indicator for closed-basin lakes. Palaeogeography, Palaeoclimatology, Palaeoecology, 133, 69-80.

Lin, Z., Wang, Q., Feng, D., Liu, Q., Chen, D., 2011. Post-depositional origin of highly ${ }^{13}$ Cdepleted carbonate in the Doushantuo cap dolostone in South China: Insights from petrography and stable carbon isotopes. Sedimentary Geology, 242, 71-79. Letters, 2, 24-34. reorganization of biogeochemical cycles. Nature, 376, 53-56.

Lohmann, K.C., 1988. Geochemical patterns of meteoric diagenetic systems and their application New York City, pp. 58-80.

1306 Loyd, S.J., Marenco, P.J., Hagadorn, J.W., Lyons, T.W., Kaufman, A.J., Sour-Tovar, F., Corsetti, 
F.A., 2012. Sustained low marine sulfate concentrations from the Neoproterozoic to the Cambrian: Insights from carbonates of northwestern Mexico and eastern California. Earth and Planetary Science Letters, 339-340, 79-94.

Loyd, S.J., Marenco, P.J., Hagadorn, J.W., Lyons, T.W., Kaufman, A.J., Sour-Tovar, F., Corsetti, F.A., 2013. Local $\delta^{34} \mathrm{~S}$ variability in $\sim 580 \mathrm{Ma}$ carbonates of northwestern Mexico and the Neoproterozoic marine sulfate reservoir. Precambrian Research, 224, 551-569.

Loyd, S.J., Corsetti, F.A., Eagle, R.A., Hagadorn, J.W., Shen, Y., Zhang, X., Bonifacie, M., Tripati, A.K., 2015. Evolution of Neoproterozoic Wonoka-Shuram Anomaly-aged carbonates: Evidence from clumped isotope paleothermometry. Precambrian Research, 264, 179-191.

Lu, M., Zhu, M., Zhang, J., Shields-Zhou, G., Li, G., Zhao, F., Zhao, X., Zhao, M., 2013. The DOUNCE event at the top of the Ediacaran Doushantuo Formation, South China: Broad stratigraphic occurrence and non-diagenetic origin. Precambrian Research, 225, 86-109.

Lyons, T.W., Reinhard, C.T., Planavsky, N.J., 2014. The rise of oxygen in Earth's early ocean and atmosphere. Nature, 506, 307-315.

Macdonald, F.A., Strauss, J.V., Sperling, E.A., Halverson, G.P., Narbonne, G.M., Johnston, D.T., Kunzmann, M., Schrag, D.P., Higgins, J.A., 2013. The stratigraphic relationship between the Shuram carbon isotope excursion, the oxygenation of Neoproterozoic oceans, and the first appearance of the Ediacara biota and bilaterian trace fossils in northwestern Canada. Chemical Geology, 362, 250-272.

Macouin, M., Ader, M., Moreau, M.-G., Poitou, C., Yang, Z., Sun, Z., 2012. Deciphering the impact of diagenesis overprint on negative $\delta^{13} \mathrm{C}$ excursions using rock magnetism: Case study of Ediacaran carbonates, Yangjiaping section, South China. Earth and Planetary Science Letters, 351-352, 281-294.

Maloof, A.C., Porter, S.M., Moore, J.L., Dudás, F.Ö., Bowring, S.A., Higgins, J.A., Fike, D.A., Eddy, M.P., 2010a. The earliest Cambrian record of animals and ocean geochemical change. Geological Society of America Bulletin, 122, 1731-1774.

Maloof, A.C., Ramezani, J., Bowring, S.A., Fike, D.A., Porter, S.M., Mazouad, M., $2010 b$. Constraints on early Cambrian carbon cycling from the duration of the Nemakit-DaldynianTommotian boundary $\delta^{13} \mathrm{C}$ shift, Morocco. Geology, 38, 623-626.

Marshall, J.D., 1992. Climatic and oceanographic isotopic signals from the carbonate rock record and their preservation. Geological magazine, 129, 143-160.

McFadden, K.A., Huang, J., Chu, X., Jiang, G., Kaufman, A.J., Zhou, C., Yuan, X., Xiao, S., 2008. Pulsed oxidation and biological evolution in the Ediacaran Doushantuo Formation. Proceedings of the National Academy of Sciences, 105, 3197-3202.

McMurtry, G.M., 2009. Authigenic deposits. In: Steele, J.H., Thorpe, S.A., Turekian, K.K. (Eds.), Marine Chemistry \& Geochemistry: A derivative of the Encyclopedia of Ocean Sciences, 2nd Edition. Elsevier, Oxford, pp. 325-335. 
Meister, P., 2013. Two opposing effects of sulfate reduction on carbonate precipitation in normal marine, hypersaline, and alkaline environments. Geology, 41, 499-502.

Meister, P., 2015. For the deep biosphere, the present is not always the key to the past: what we can learn from the geological record. Terra Nova, 27, 400-408.

Melezhik, V.A., Fallick, A.E., Smith, R.A., Rosse, D.M., 2007. Spherical and columnar, septarian, ${ }^{18} \mathrm{O}$-depleted, calcite concretions from Middle-Upper Permian lacustrine siltstones in northern Mozambique: evidence for very early diagenesis and multiple fluids. Sedimentology, 54, 13891416.

Melezhik, V.A., Pokrovsky, B.G., Fallick, A.E., Kuznetsov, A.B., Bujakaite, M.I., 2009. Constraints on ${ }^{87} \mathrm{Sr} /{ }^{86} \mathrm{Sr}$ of Late Ediacaran seawater: insight from Siberian high-Sr limestones. Journal of the Geological Society, 166, 183-191.

Metzger, J.G., Fike, D.A., 2013. Techniques for assessing spatial heterogeneity of carbonate $\delta^{13} \mathrm{C}$ values: Implications for craton-wide isotope gradients. Sedimentology, 60, 1405-1431.

Mishra, P.K., Prasad, S., Anoop, A., Plessen, B., Jehangir, A., Gaye, B., Menzel, P., Weise, S.M., Yousuf, A.R., 2015. Carbonate isotopes from high altitude Tso Moriri Lake (NW Himalayas) provide clues to late glacial and Holocene moisture source and atmospheric circulation changes. Palaeogeography, Palaeoclimatology, Palaeoecology, 425, 76-83.

Moore, C.H., 1989. Carbonate Diagenesis and Porosity, 46. Elsevier.

Moore, C.H., 2004. Carbonate Reservoirs: Porosity Evolution and Diagenesis in a Sequence Stratigraphic Framework.

Moore, T.S., Murray, R., Kurtz, A., Schrag, D., 2004. Anaerobic methane oxidation and the formation of dolomite. Earth and Planetary Science Letters, 229, 141-154.

Morad, S., Ketzer, J.M., De Ros, L.F., 2013. Linking Diagenesis to Sequence Stratigraphy: An Integrated Tool for Understanding and Predicting Reservoir Quality Distribution. John Wiley \& Sons, Inc., 1-36 pp.

Morse, J., 2003. Formation and diagenesis of carbonate sediments. In: Holland, H.D., Turekian, K.K. (Eds.), Treatise on Geochemistry, Volume 7: Sediments, Diagenesis, and Sedimentary Rocks. Elsevier, Oxford, pp. 67-85.

Morse, J.W., Mackenzie, F.T., 1990. Geochemistry of Sedimentary Carbonates. Elsevier, Amsterdam.

Mozley, P.S., Burns, S.J., 1993. Oxygen and carbon isotopic composition of marine carbonate concretions: An overview. Journal of Sedimentary Research, 63, 73-83.

Muehlenbachs, K., Clayton, R.N., 1976. Oxygen isotope composition of the oceanic crust and its bearing on seawater. Journal of Geophysical Research, 81, 4365-4369. 
Muehlenbachs, K., 1998. The oxygen isotopic composition of the oceans, sediments and the seafloor. Chemical Geology, 145, 263-273.

Muscente, A.D., Hawkins, A.D., Xiao, S., 2015. Fossil preservation through phosphatization and silicification in the Ediacaran Doushantuo Formation (South China): a comparative synthesis. Palaeogeography, Palaeoclimatology, Palaeoecology, 434, 46-62.

Naehr, T.H., Rodriguez, N.M., Bohrmann, G., Paull, C.K., Botz, R., 2000. Methane-derived authigenic carbonates associated with gas hydrate decomposition and fluid venting above the Blake Ridge Diapir. In: Paull, C.K., Matsumoto, R., Wallace, P.J., Dillon, W.P. (Eds.), Proceedings of the Ocean Drilling Program. Scientific Results. Ocean Drilling Program, pp. 285-300.

Narbonne, G.M., Xiao, S., Shields, G.A., Gehling, J.G., 2012. The Ediacaran Period. In: Gradstein, F.M., Ogg, J.G., Schmitz, M.D., Ogg, G.M. (Eds.), The Geologic Time Scale. Elsevier, Boston, pp. 413-435.

Niu, D., Renock, D., Whitehouse, M., Leone, J., Rowe, H., Landis, J., Hamren, K., Symcox, C.W., Sharma, M., 2016. A relict sulfate-methane transition zone in the mid-Devonian Marcellus Shale. Geochimica et Cosmochimica Acta, 182, 73-87.

Northrop, D.A., Clayton, R.N., 1966. Oxygen-isotope fractionations in systems containing dolomite. The Journal of Geology, 174-196.

Nyman, S.L., Nelson, C.S., 2011. The place of tubular concretions in hydrocarbon cold seep systems: Late Miocene Urenui Formation, Taranaki Basin, New Zealand. AAPG Bulletin, 95, $1495-1524$.

O'Neil, J.R., Epstein, S., 1966. Oxygen isotope fractionation in the system dolomite-calcitecarbon dioxide. Science, 152, 198-201.

Oehlert, A.M., Swart, P.K., 2014. Interpreting carbonate and organic carbon isotope covariance in the sedimentary record. Nature Communications, 5, 4672.

Osburn, M., Grotzinger, J., Bergmann, K., 2014. Facies, stratigraphy, and evolution of a middle Ediacaran carbonate ramp: Khufai Formation, Sultanate of Oman. AAPG Bulletin, 98, 16311667.

Osburn, M.R., Owens, J., Bergmann, K.D., Lyons, T.W., Grotzinger, J.P., 2015. Dynamic changes in sulfate sulfur isotopes preceding the Ediacaran Shuram Excursion. Geochimica et Cosmochimica Acta, 170, 204-224.

Pavlov, A.A., Hurtgen, M.T., Kasting, J.F., Arthur, M.A., 2003. Methane-rich Proterozoic atmosphere? Geology, 31, 87-90.

Peckmann, J., Reimer, A., Luth, U., Luth, C., Hansen, B.T., Heinicke, C., Hoefs, J., Reitner, J., 2001. Methane-derived carbonates and authigenic pyrite from the northwestern Black Sea. Marine Geology, 177, 129-150. 
1414 Peng, Y., Bao, H., Zhou, C., Yuan, X., Luo, T., 2013. Oxygen isotope composition of meltwater from a Neoproterozoic glaciation in South China. Geology, 41, 367-370.

1416 Planavsky, N.J., Reinhard, C.T., Wang, X., Thomson, D., McGoldrick, P., Rainbird, R.H., Johnson, T., Fischer, W.W., Lyons, T.W., 2014. Low Mid-Proterozoic atmospheric oxygen levels and the delayed rise of animals. Science, 346, 635-638.

Pruss, S.B., Corsetti, F.A., Fischer, W.W., 2008. Seafloor-precipitated carbonate fans in the

1422 Quinn, T.M., 1991. Meteoric diagenesis of Plio-Pleistocene limestones at Enewetak atoll. Journal 1423 of Sedimentary Research, 61, 681-703.

1424 Riedinger, N., Kasten, S., Gröger, J., Franke, C., Pfeifer, K., 2006. Active and buried authigenic barite fronts in sediments from the Eastern Cape Basin. Earth and Planetary Science Letters, 241, 876-887.

1427 Riedinger, N., Formolo, M.J., Lyons, T.W., Henkel, S., Beck, A., Kasten, S., 2014. An inorganic geochemical argument for coupled anaerobic oxidation of methane and iron reduction in marine sediments. Geobiology, 12, 172-181.

Ritger, S., Carson, B., Suess, E., 1987. Methane-derived authigenic carbonates formed by subduction-induced pore-water expulsion along the Oregon/Washington margin. Geological 1432 Society of America Bulletin, 98, 147-156.

1433 Rohling, E.J., 2007. Oxygen isotope composition of seawater. In: A., E.S. (Ed.), Encyclopedia of quaternary science. Elsevier, Amsterdam, pp. 915-922.

1435 Saitoh, M., Ueno, Y., Isozaki, Y., Shibuya, T., Yao, J., Ji, Z., Shozugawa, K., Matsuo, M., in China: Implications for the carbon cycle in ancient anoxic oceans. Progress in Earth and 1438 Planetary Science, 2, 41.

Sass, E., Bein, A., Almogi-Labin, A., 1991. Oxygen-isotope composition of diagenetic calcite in organic-rich rocks: Evidence for ${ }^{18} \mathrm{O}$ depletion in marine anaerobic pore water. Geology, 19, 839-842.

Sawaki, Y., Ohno, T., Tahata, M., Komiya, T., Hirata, T., Maruyama, S., Windley, B.F., Han, J., Shu, D., Li, Y., 2010. The Ediacaran radiogenic Sr isotope excursion in the Doushantuo Formation in the Three Gorges area, South China. Precambrian Research, 176, 46-64. 
Schobben, M., Ullmann, C.V., Leda, L., Korn, D., Struck, U., Reimold, W.U., Ghaderi, A., Algeo, T.J., Korte, C., 2016. Discerning primary versus diagenetic signals in carbonate carbon and oxygen isotope records: An example from the Permian-Triassic boundary of Iran. Chemical Geology, 422, 94-107.

Schrag, D.P., Higgins, J.A., Macdonald, F.A., Johnston, D.T., 2013. Authigenic carbonate and the history of the global carbon cycle. Science, 339, 540-543.

Shaffer, G., 1986. Phosphate pumps and shuttles in the Black Sea. Nature, 321, 515-517.

Shen, B., Dong, L., Xiao, S., Lang, X., Huang, K., Peng, Y., Zhou, C., Ke, S., Liu, P., 2016. Molar tooth carbonates and benthic methane fluxes in Proterozoic oceans. Nature Communications, 7, 10317.

Shen, Y., Pinti, D.L., Hashizume, K., 2006. Biogeochemical cycles of sulfur and nitrogen in the Archean ocean and atmosphere. Archean geodynamics and environments, 305-320.

Sheppard, S.M.F., Schwarcz, H.P., 1970. Fractionation of carbon and oxygen isotopes and magnesium between coexisting metamorphic calcite and dolomite. Contributions to Mineralogy and Petrology, 26, 161-198.

Śliwiński, M.G., Kozdon, R., Kitajima, K., Valley, J.W., Denny, A., 2016. Microanalysis of carbonate cement $\delta^{18} \mathrm{O}$ in a $\mathrm{CO}_{2}$-storage system seal: insights into the diagenetic history of the Eau Claire Formation (Upper Cambrian), Illinois Basin. AAPG Bulletin, 1003-1031.

Sperling, E.A., Wolock, C.J., Morgan, A.S., Gill, B.C., Kunzmann, M., Halverson, G.P., Macdonald, F.A., Knoll, A.H., Johnston, D.T., 2015. Statistical analysis of iron geochemical data suggests limited late Proterozoic oxygenation. Nature, 523, 451-454.

Spero, H.J., Bijma, J., Lea, D.W., Bemis, B.E., 1997. Effect of seawater carbonate concentration on foraminiferal carbon and oxygen isotopes. Nature, 390, 497-500.

Suess, E., 2014. Marine cold seeps and their manifestations: geological control, biogeochemical criteria and environmental conditions. International Journal of Earth Sciences, 103, 1889-1916.

Summa, C.L., 1993. Sedimentologic, stratigraphic, and tectonic controls of a mixed carbonatesiliciclastic succession: Neoproterozoic Johnnie formation, southeast California, Massachusetts Institute of Technology.

Sun, X., Turchyn, A.V., 2014. Significant contribution of authigenic carbonate to marine carbon burial. Nature Geoscience, 7, 201-204.

Swart, P.K., Kennedy, M.J., 2012. Does the global stratigraphic reproducibility of $\delta^{13} \mathrm{C}$ in Neoproterozoic carbonates require a marine origin? A Pliocene-Pleistocene comparison. Geology, 40, 87-90.

Tahata, M., Ueno, Y., Ishikawa, T., Sawaki, Y., Murakami, K., Han, J., Shu, D., Li, Y., Guo, J., Yoshida, N., Komiya, T., 2013. Carbon and oxygen isotope chemostratigraphies of the Yangtze 
1484

1485

1486

1487

1488

1489

1490

1491

1492

1493

1494

1495

1496

1497

1498

1499

1500

1501

1502

1503

1504

1505

1506

1507

1508

1509

1510

1511

1512

1513

1514

1515

1516

1517

1518

1519

platform, South China: Decoding temperature and environmental changes through the Ediacaran. Gondwana Research, 23, 333-353.

Talbot, M., Kelts, K., 1986. Primary and diagenetic carbonates in the anoxic sediments of Lake Bosumtwi, Ghana. Geology, 14, 912-916.

Teichert, B.M., Gussone, N., Eisenhauer, A., Bohrmann, G., 2005. Clathrites: archives of nearseafloor pore-fluid evolution $\left(\delta^{44 / 40} \mathrm{Ca}, \delta^{13} \mathrm{C}, \delta^{18} \mathrm{O}\right)$ in gas hydrate environments. Geology, 33, 213-216.

Thomazo, C., Vennin, E., Brayard, A., Bour, I., Mathieu, O., Elmeknassi, S., Olivier, N., Escarguel, G., Bylund, K.G., Jenks, J., Stephen, D.A., Fara, E., 2016. A diagenetic control on the Early Triassic Smithian-Spathian carbon isotopic excursions recorded in the marine settings of the Thaynes Group (Utah, USA). Geobiology, 14, 220-236.

Torres, M.E., Brumsack, H., Bohrmann, G., Emeis, K., 1996. Barite fronts in continental margin sediments: a new look at barium remobilization in the zone of sulfate reduction and formation of heavy barites in diagenetic fronts. Chemical Geology, 127, 125-139.

Tucker, M.E., 1982. Precambrian dolomites: petrographic and isotopic evidence that they differ from Phanerozoic dolomites. Geology, 10, 7-12.

Tucker, M.E., 1983. Diagenesis, geochemistry, and origin of a Precambrian dolomite: the Beck Spring Dolomite of eastern California. Journal of Sedimentary Research, 53, 1097-1119.

Tucker, M.E., Wright, V.P., 1990. Carbonate Sedimentology. Blackwell Scientific Publications, Oxford.

Vanneste, H., James, R.H., Kelly-Gerreyn, B.A., Mills, R.A., 2013. Authigenic barite records of methane seepage at the Carlos Ribeiro mud volcano (Gulf of Cadiz). Chemical Geology, 354, $42-54$.

Veizer, J., Bruckschen, P., Pawellek, F., Diener, A., Podlaha, O.G., Carden, G.A., Jasper, T., Korte, C., Strauss, H., Azmy, K., 1997. Oxygen isotope evolution of Phanerozoic seawater. Palaeogeography, Palaeoclimatology, Palaeoecology, 132, 159-172.

Veizer, J., Ala, D., Azmy, K., Bruckschen, P., Buhl, D., Bruhn, F., Carden, G.A., Diener, A., Ebneth, S., Godderis, Y., 1999. ${ }^{87} \mathrm{Sr} /{ }^{86} \mathrm{Sr}, \delta^{13} \mathrm{C}$ and $\delta^{18} \mathrm{O}$ evolution of Phanerozoic seawater. Chemical Geology, 161, 59-88.

Walter, L.M., Burton, E.A., 1990. Dissolution of recent platform carbonate sediments in marine pore fluids. American Journal of Science, 290, 601-643.

Walter, L.M., Bischof, S.A., Patterson, W.P., Lyons, T.W., O'Nions, R., Gruszczynski, M., Sellwood, B., Coleman, M., 1993. Dissolution and recrystallization in modern shelf carbonates: evidence from pore water and solid phase chemistry [and discussion]. Philosophical Transactions of the Royal Society of London A: Mathematical, Physical and Engineering Sciences, 344, 2736. 
Wang, J., Jiang, G., Xiao, S., Li, Q., Wei, Q., 2008. Carbon isotope evidence for widespread methane seeps in the ca. 635 Ma Doushantuo cap carbonate in south China. Geology, 36, 347350.

Wang, W., Zhou, C., Guan, C., Yuan, X., Chen, Z., Wan, B., 2014. An integrated carbon, oxygen, and strontium isotopic studies of the Lantian Formation in South China with implications for the Shuram anomaly. Chemical Geology, 373, 10-26.

Wang, X., Jiang, G., Shi, X., Xiao, S., 2016. Paired carbonate and organic carbon isotope variations of the Ediacaran Doushantuo Formation from an upper slope section at Siduping, South China. Precambrian Research, 273, 53-66.

Watkins, J.M., Hunt, J.D., Ryerson, F.J., DePaolo, D.J., 2014. The influence of temperature, pH, and growth rate on the $\delta^{18} \mathrm{O}$ composition of inorganically precipitated calcite. Earth and Planetary Science Letters, 404, 332-343.

Wright, V.P., Cherns, L., 2016. Leaving no stone unturned: the feedback between increased biotic diversity and early diagenesis during the Ordovician. Journal of the Geological Society, 173, 241-244.

Xiao, S., Schiffbauer, J.D., McFadden, K.A., Hunter, J., 2010. Petrographic and SIMS pyrite sulfur isotope analyses of Ediacaran chert nodules: Implications for microbial processes in pyrite rim formation, silicification, and exceptional fossil preservation. Earth and Planetary Science Letters, 297, 481-495.

Xiao, S., McFadden, K.A., Peek, S., Kaufman, A.J., Zhou, C., Jiang, G., Hu, J., 2012. Integrated chemostratigraphy of the Doushantuo Formation at the northern Xiaofenghe section (Yangtze Gorges, South China) and its implication for Ediacaran stratigraphic correlation and ocean redox models. Precambrian Research, 192-195, 125-141.

Xiao, S., Narbonne, G.M., Zhou, C., Laflamme, M., Grazhdankin, D.V., Moczydłowska-Vidal, M., Cui, H., 2016. Toward an Ediacaran time scale: Problems, protocols, and prospects. Episodes, $39,540-555$.

$\mathrm{Xu}, \mathrm{H} ., 2$ 2010. Synergistic roles of microorganisms in mineral precipitates associated with deep sea methane seeps. In: Barton, L.L., Mandl, M., Loy, A. (Eds.), Geomicrobiology: Molecular and Environmental Perspective. Springer, Berlin, Germany, pp. 325-346.

Zhao, M.-Y., Zheng, Y.-F., Zhao, Y.-Y., 2016. Seeking a geochemical identifier for authigenic carbonate. Nature Communications, 7, 10885.

Zhao, Y.-Y., Zheng, Y.-F., 2010. Stable isotope evidence for involvement of deglacial meltwater in Ediacaran carbonates in South China. Chemical Geology, 271, 86-100.

Zhao, Y.-Y., Zheng, Y.-F., 2015. Geochemistry of vein and wallrock carbonates from the Ediacaran system in South China: Insights into the origins of depositional and post-depositional fluids. Chemical Geology, 404, 71-87. 
1556 Zhelezinskaia, I., Kaufman, A.J., Farquhar, J., Cliff, J., 2014. Large sulfur isotope fractionations 1557 associated with Neoarchean microbial sulfate reduction. Science, 346, 742-744.

1558 Zhou, C., Xiao, S., 2007. Ediacaran $\delta^{13} \mathrm{C}$ chemostratigraphy of South China. Chemical Geology, $1559237,89-108$.

1560 Zhou, C., Bao, H., Peng, Y., Yuan, X., 2010. Timing the deposition of ${ }^{17}$ O-depleted barite at the 1561 aftermath of Nantuo glacial meltdown in South China. Geology, 38, 903-906.

1562 Zhou, C., Jiang, S., Xiao, S., Chen, Z., Yuan, X., 2012. Rare earth elements and carbon isotope 1563 geochemistry of the Doushantuo Formation in South China: Implication for middle Ediacaran 1564 shallow marine redox conditions. Chinese Science Bulletin, 57, 1998-2006.

1565 Zhou, C., Guan, C., Cui, H., Ouyang, Q., Wang, W., 2016. Methane-derived authigenic carbonate 1566 from the lower Doushantuo Formation of South China: Implications for seawater sulfate 1567 concentration and global carbon cycle in the early Ediacaran ocean. Palaeogeography, 1568 Palaeoclimatology, Palaeoecology, 461, 145-155.

1569 Zhou, X., Chen, D., Dong, S., Zhang, Y., Guo, Z., Wei, H., Yu, H., 2015. Diagenetic barite 1570 deposits in the Yurtus Formation in Tarim Basin, NW China: Implications for barium and sulfur 1571 cycling in the earliest Cambrian. Precambrian Research, 263, 79-87.

1572 Zhu, M., Zhang, J., Yang, A., 2007. Integrated Ediacaran (Sinian) chronostratigraphy of South 1573 China. Palaeogeography, Palaeoclimatology, Palaeoecology, 254, 7-61.

1574 Zhu, M., Lu, M., Zhang, J., Zhao, F., Li, G., Yang, A., Zhao, X., Zhao, M., 2013. Carbon isotope 1575 chemostratigraphy and sedimentary facies evolution of the Ediacaran Doushantuo Formation in 1576 western Hubei, South China. Precambrian Research, 225, 7-28. 
A thin bedded limestone

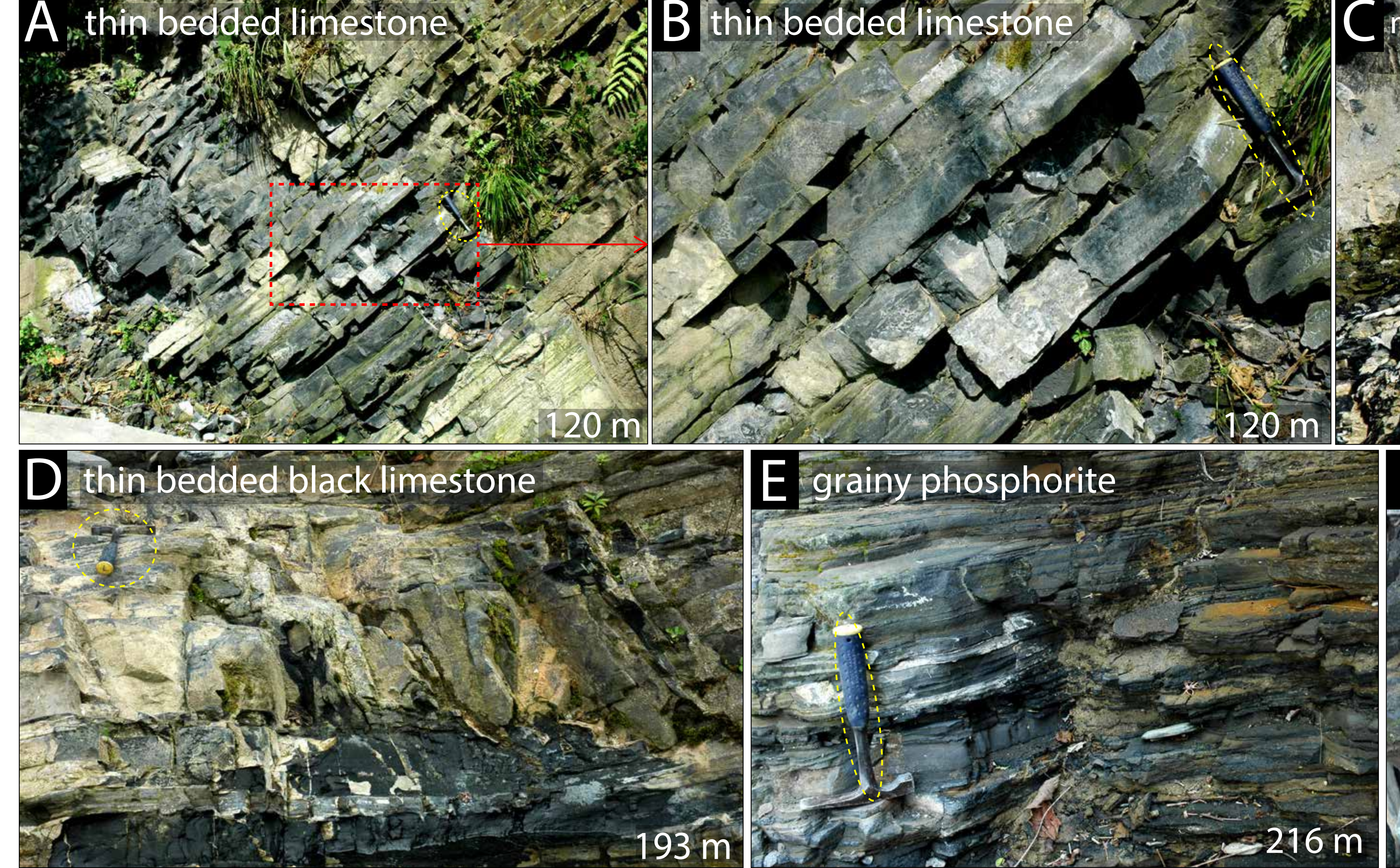

G interbedded dolomicrite layer and calleitic layers with calcite hodules

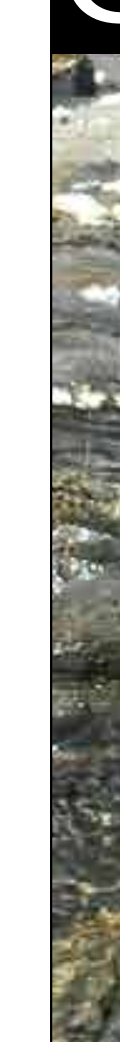

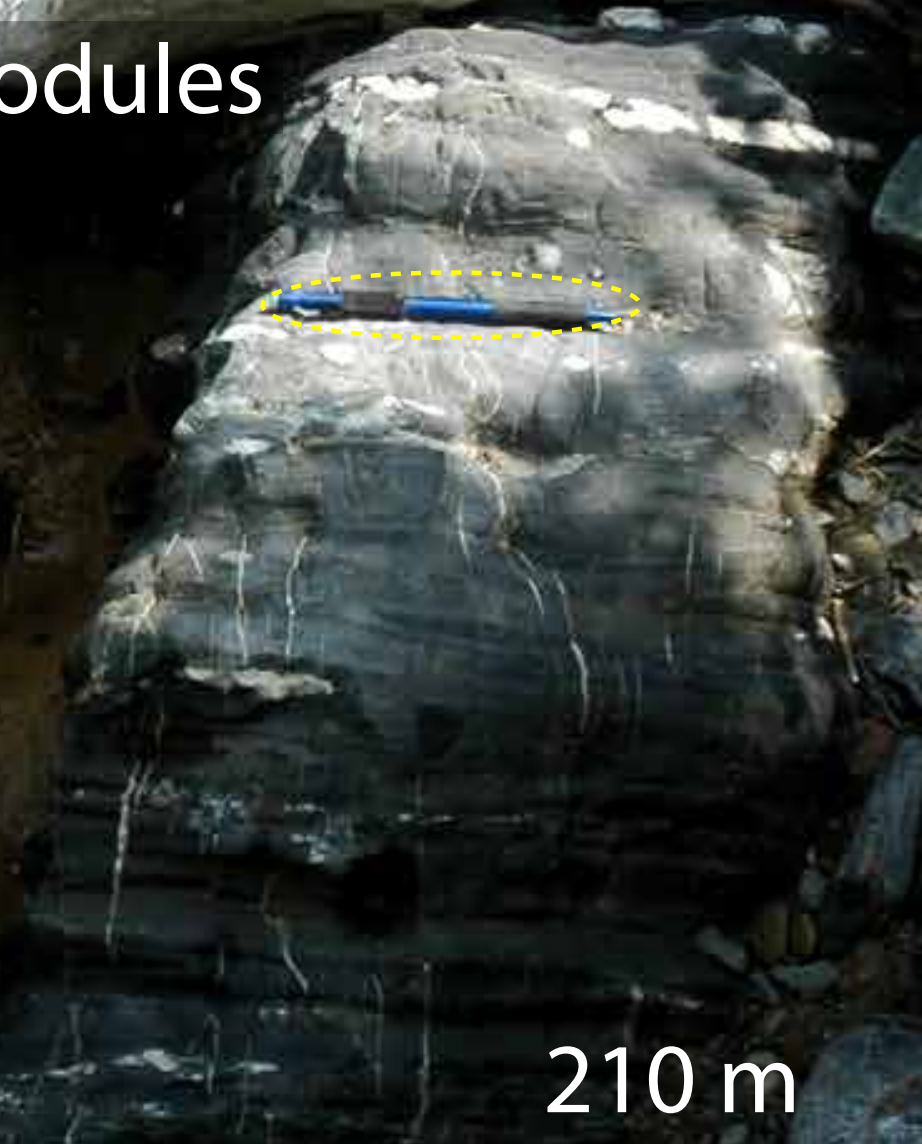

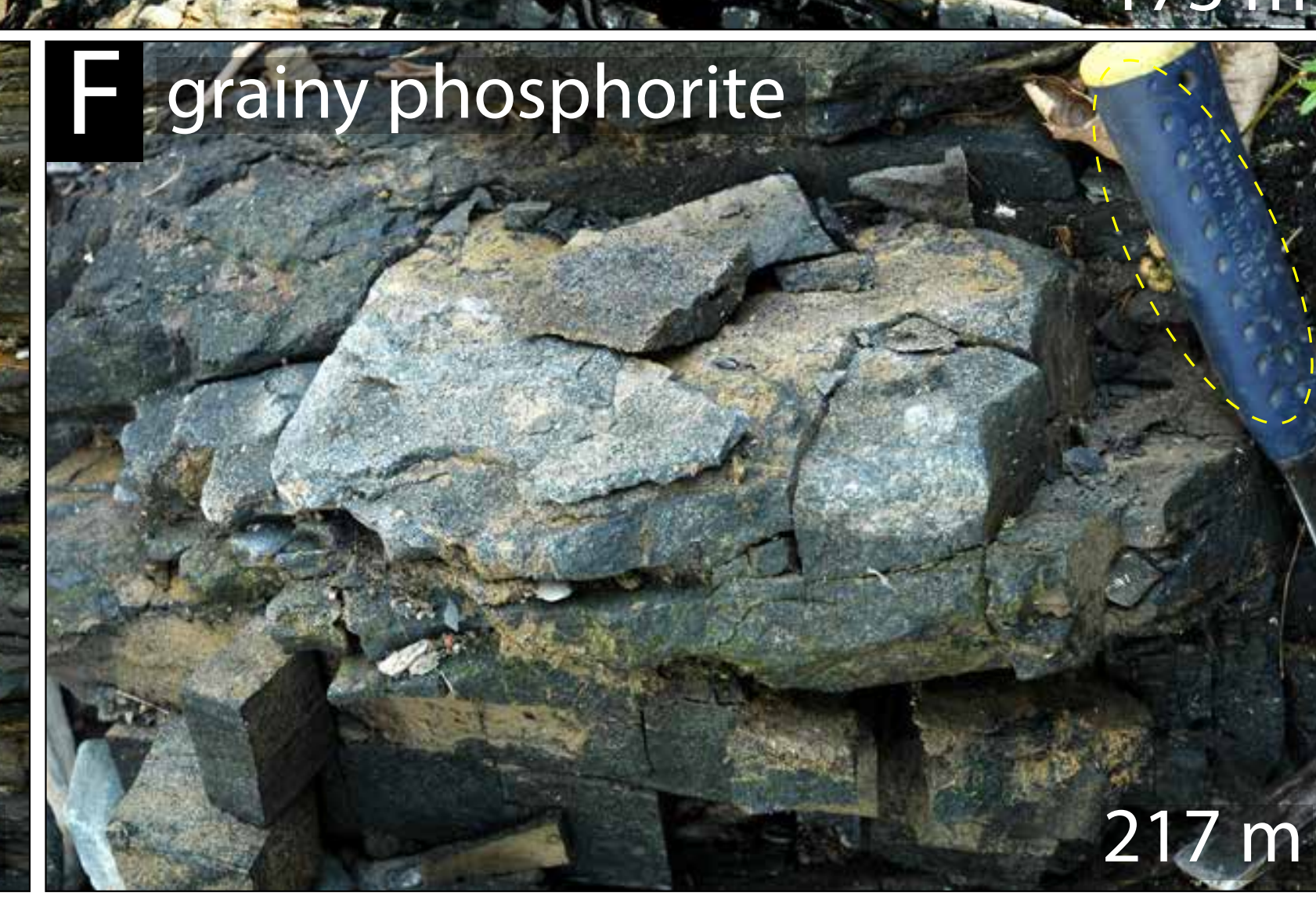

Hinterbedded dolomicrite layer and calcitic layers with calcite nodules

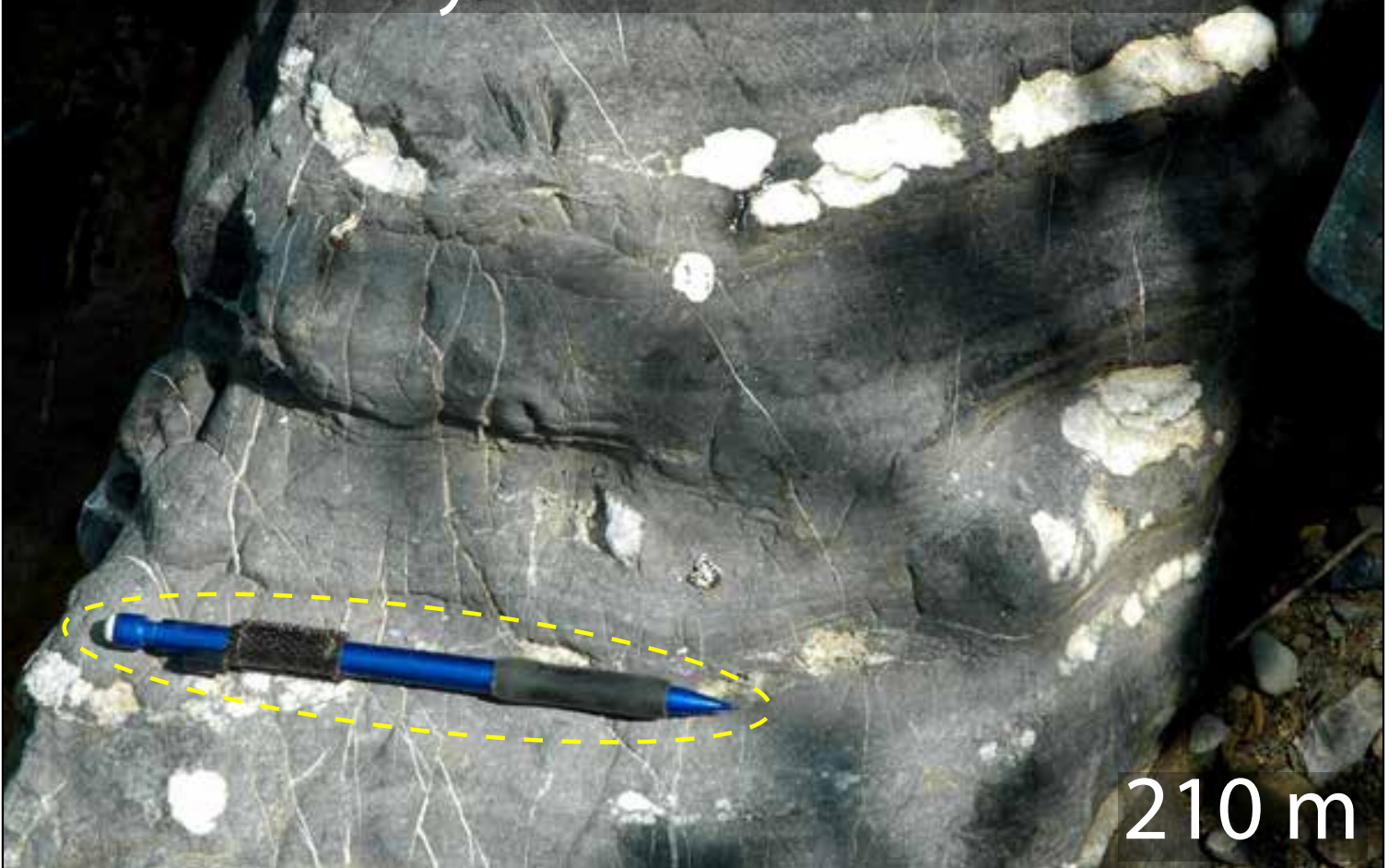

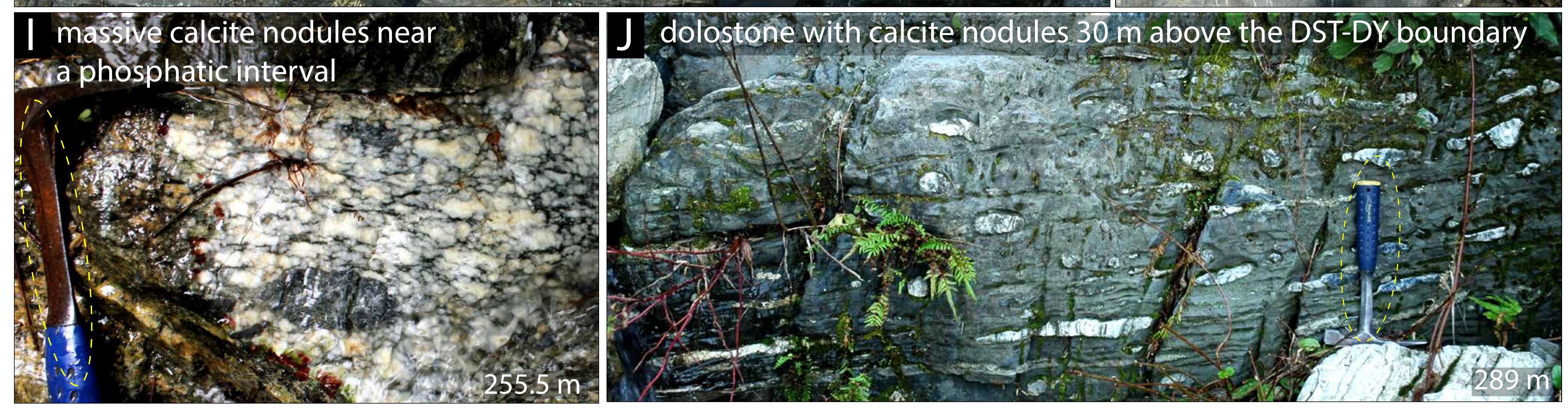




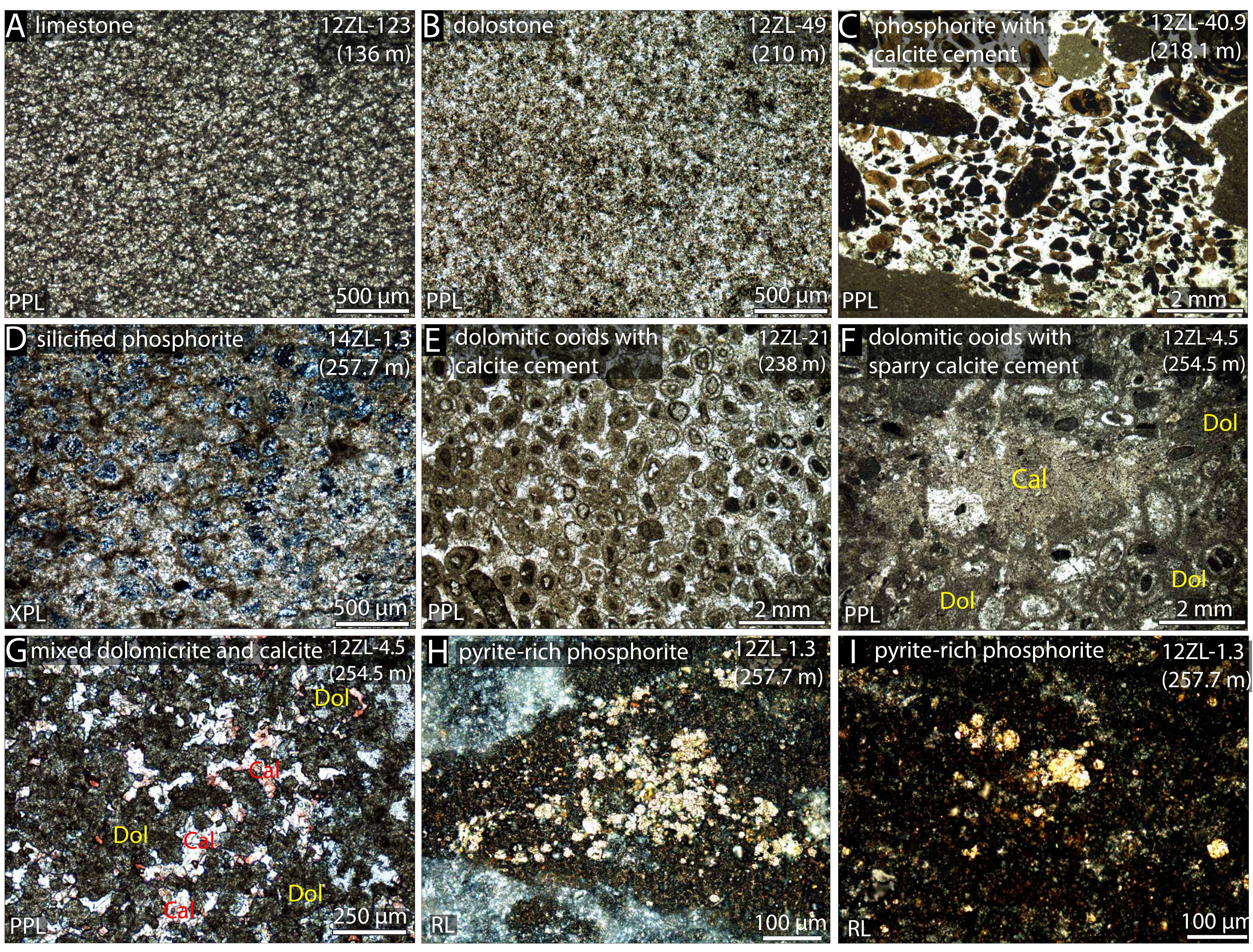




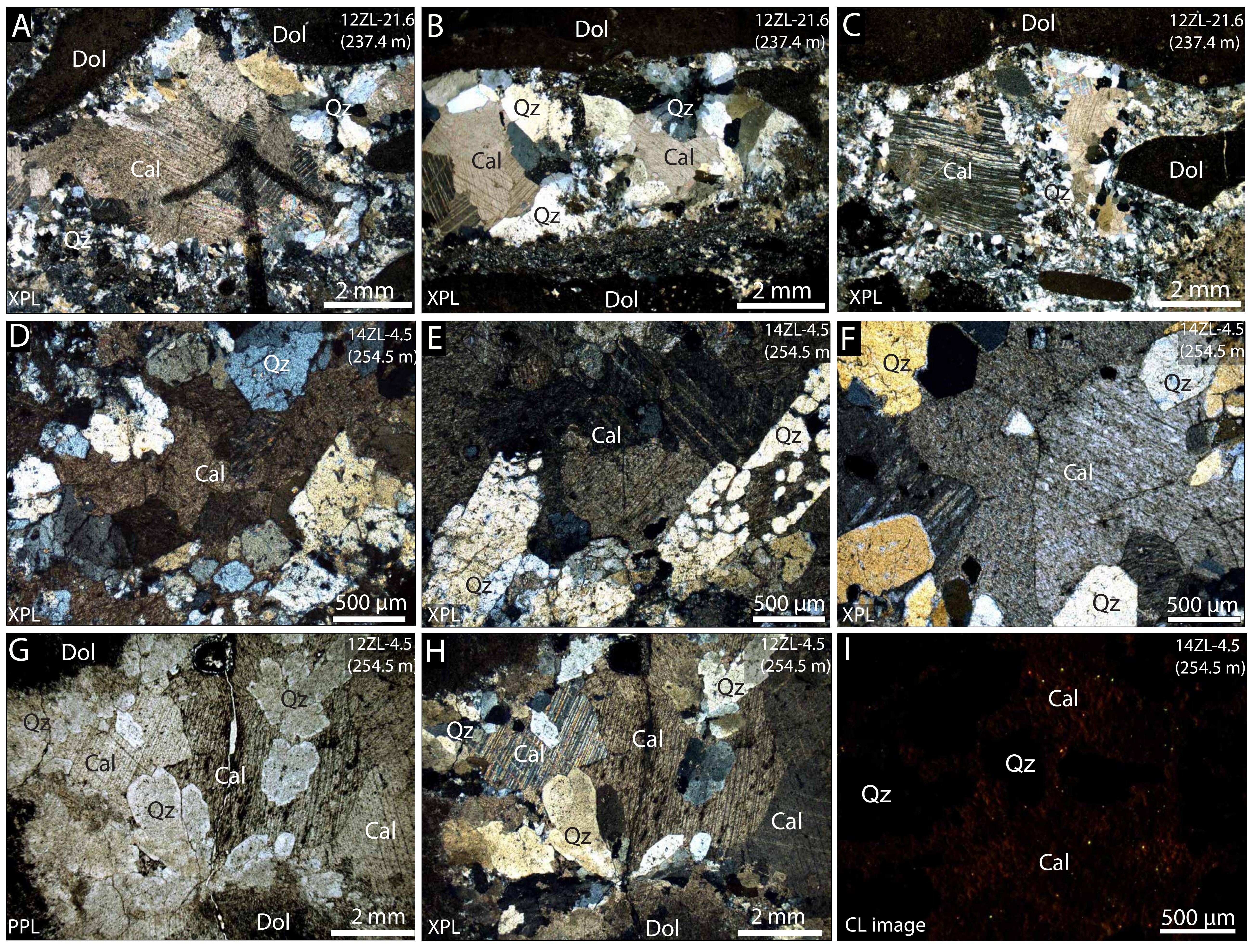




\section{The first authigenic interval in the upper Doushantuo Formation (outer-shelf Zhongling section):}

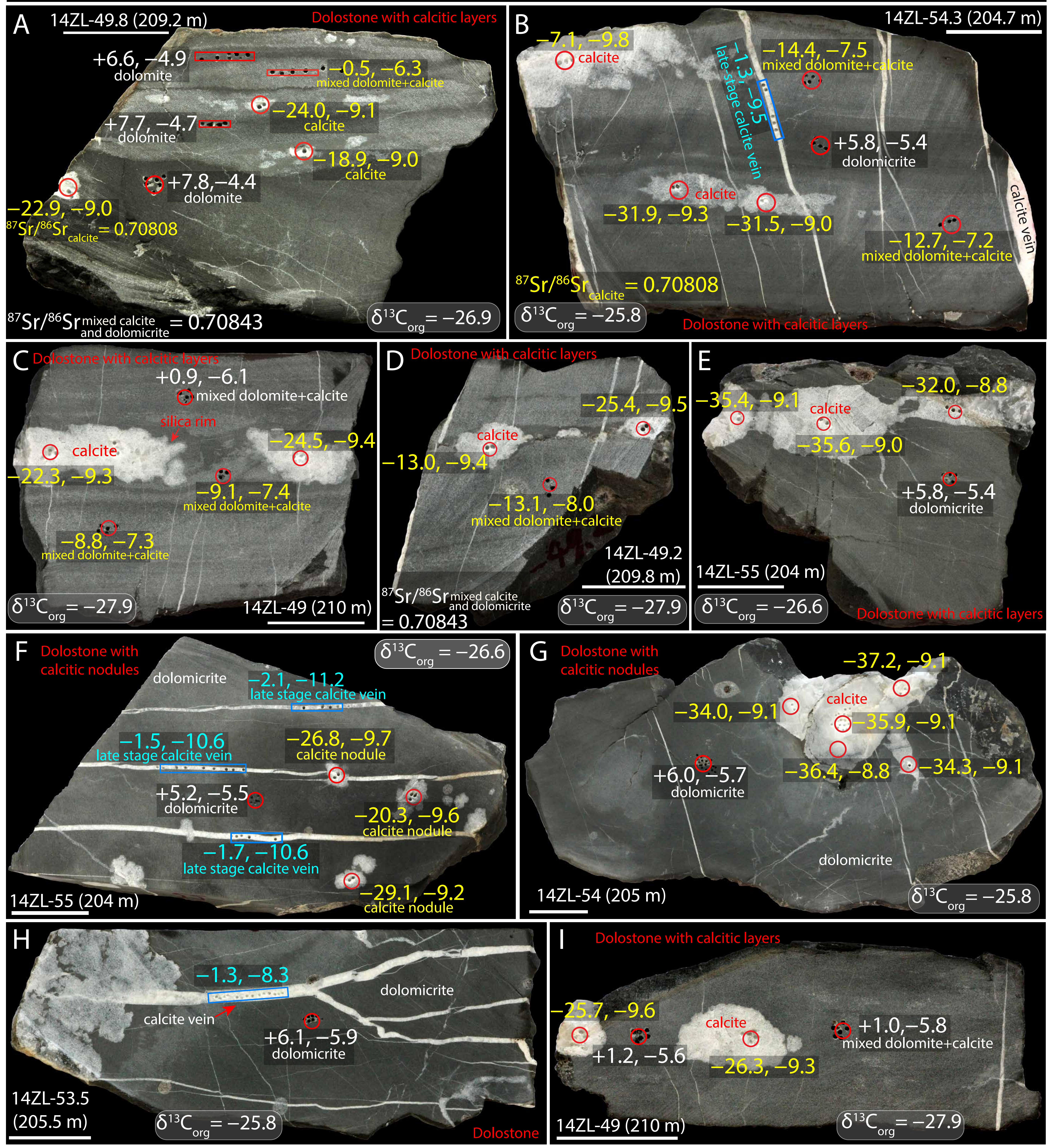

Notes:

Paired numbers "X\%o, Y\%o": " $\delta^{13} \mathrm{C}_{\text {carb' }}{ }^{18} \mathrm{O}_{\text {carb }}$ " (authigenic phase in yellow; depositional phase in white; late-stage veins in blue).

Sample 12ZL-X (Y m) or 14ZL-X (Y m): X-distance below the Doushantuo/Dengying boundary; Y-straitigraphic height above the Nantuo diamicrite 
The second authigenic interval in the upper Doushantuo Formation (outer-shelf Zhongling section):

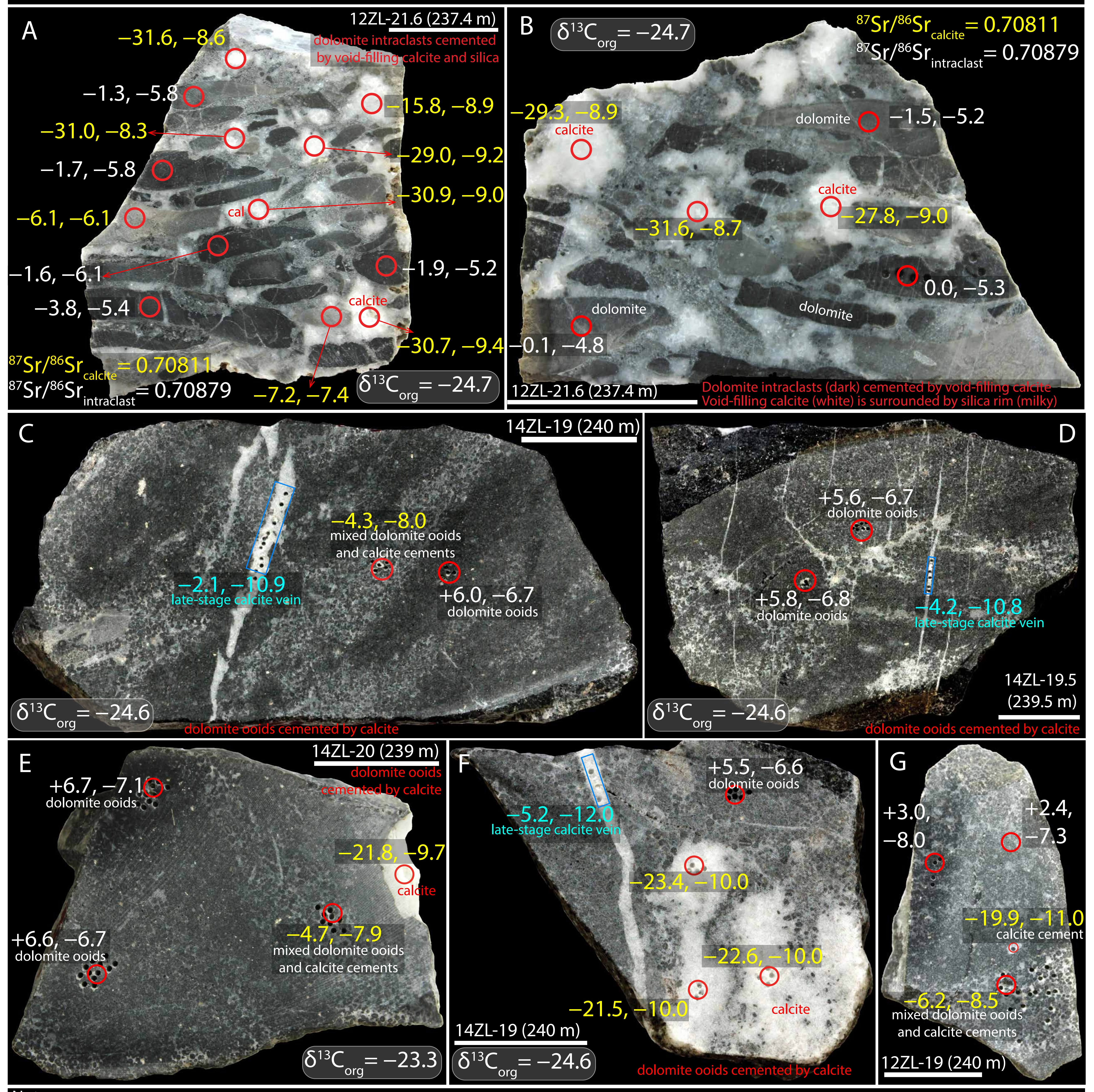

Notes:

Paired numbers "X\%o,Y\%o": " $\delta^{13} \mathrm{C}_{\text {carb" }} \delta^{18} \mathrm{O}_{\text {carb }}$ " (authigenic phase in yellow; depositional phase in white; late-stage veins in blue).

Sample 12ZL-X (Y m) or 14ZL-X (Y m): X-distance below the Doushantuo/Dengying boundary; Y-straitigraphic height above the Nantuo diamicrite. 

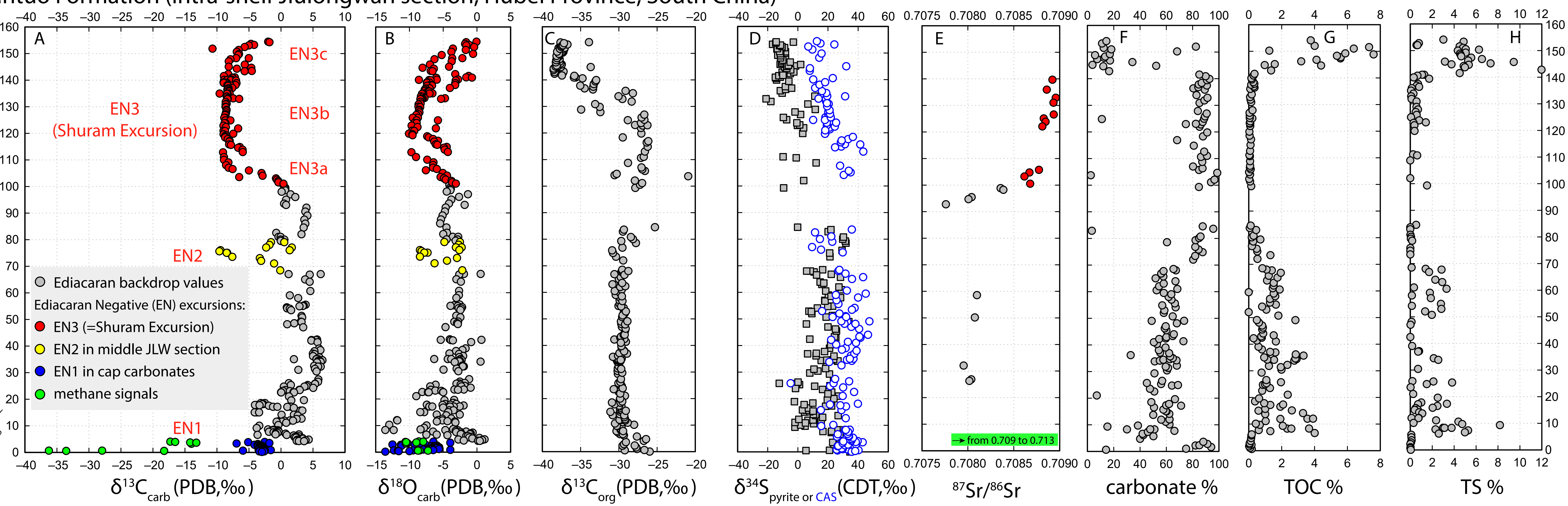

Doushantuo Formation (outer-shelf Zhongling section, Hunan Province, South China)
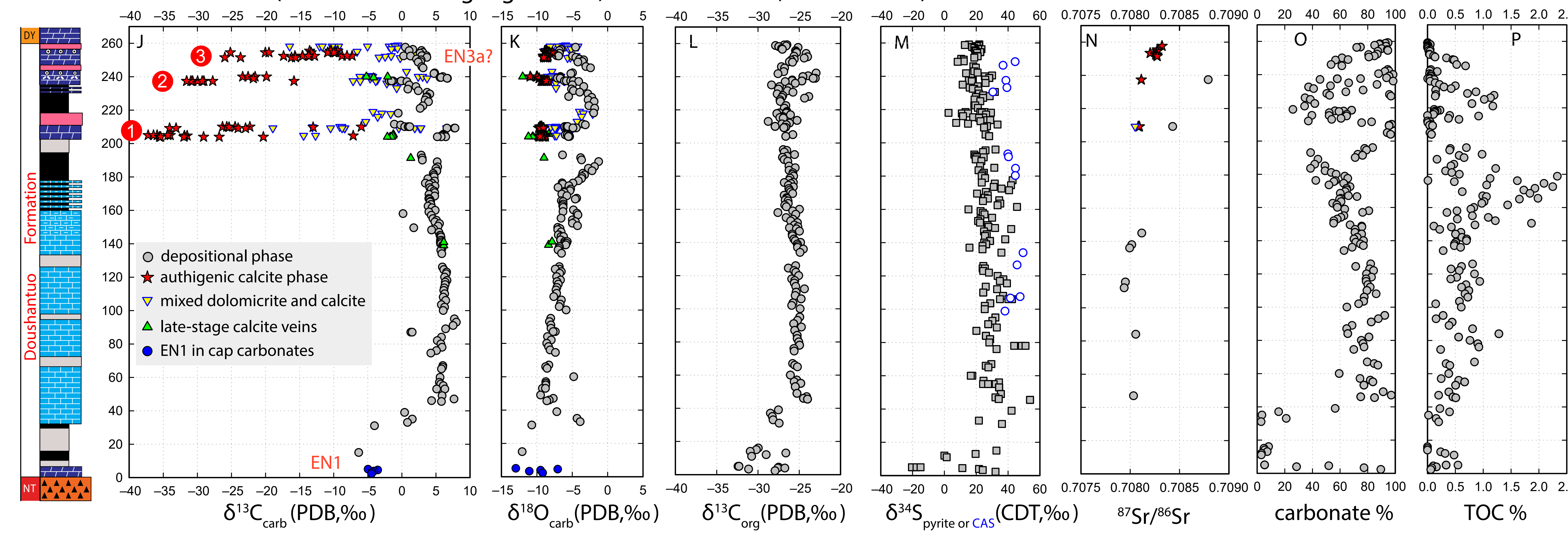

carbonate $\%$

TOC \%

TS $\%$

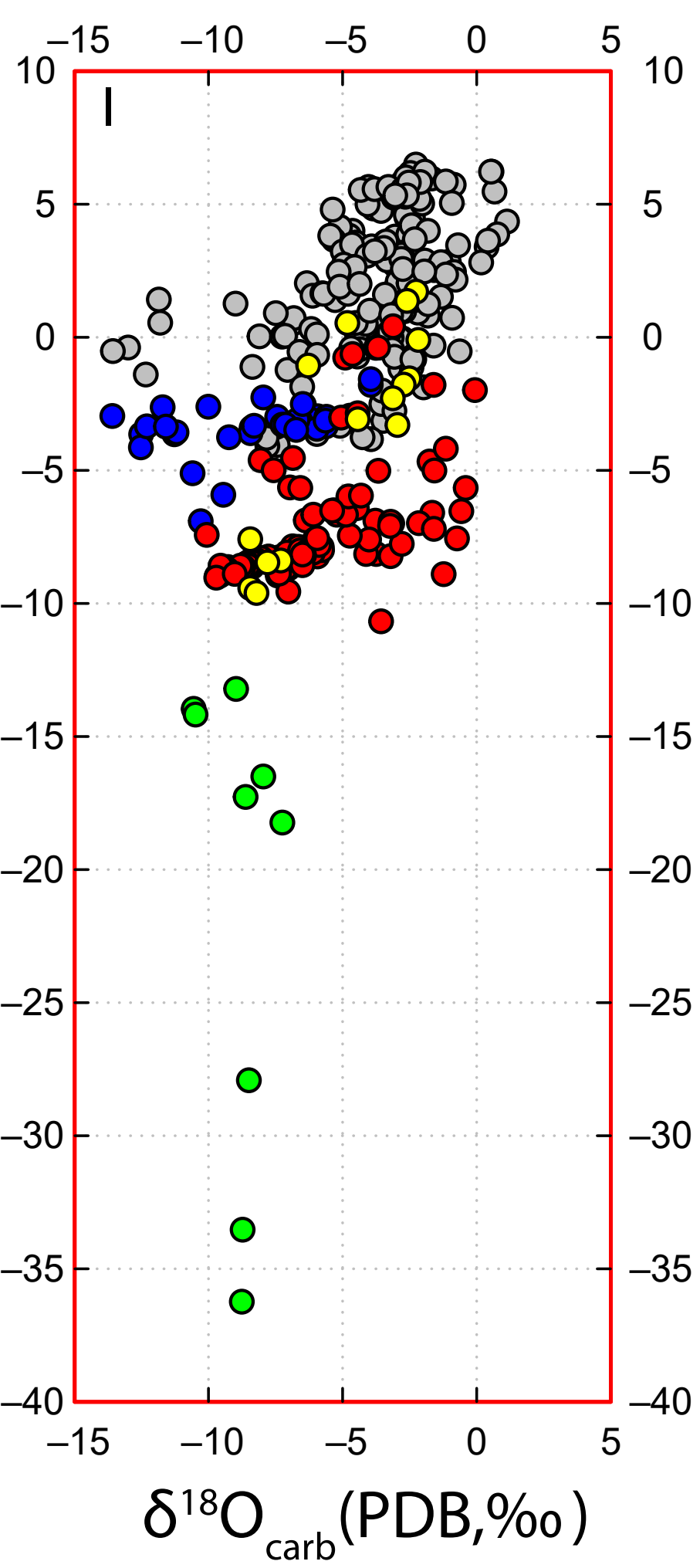

limestone dolostone

$\Delta \Delta_{\Delta}$ diamictite $\mathrm{DY}$ Dengying $\mathrm{NT}$ Nantuo $\square$ covered zone

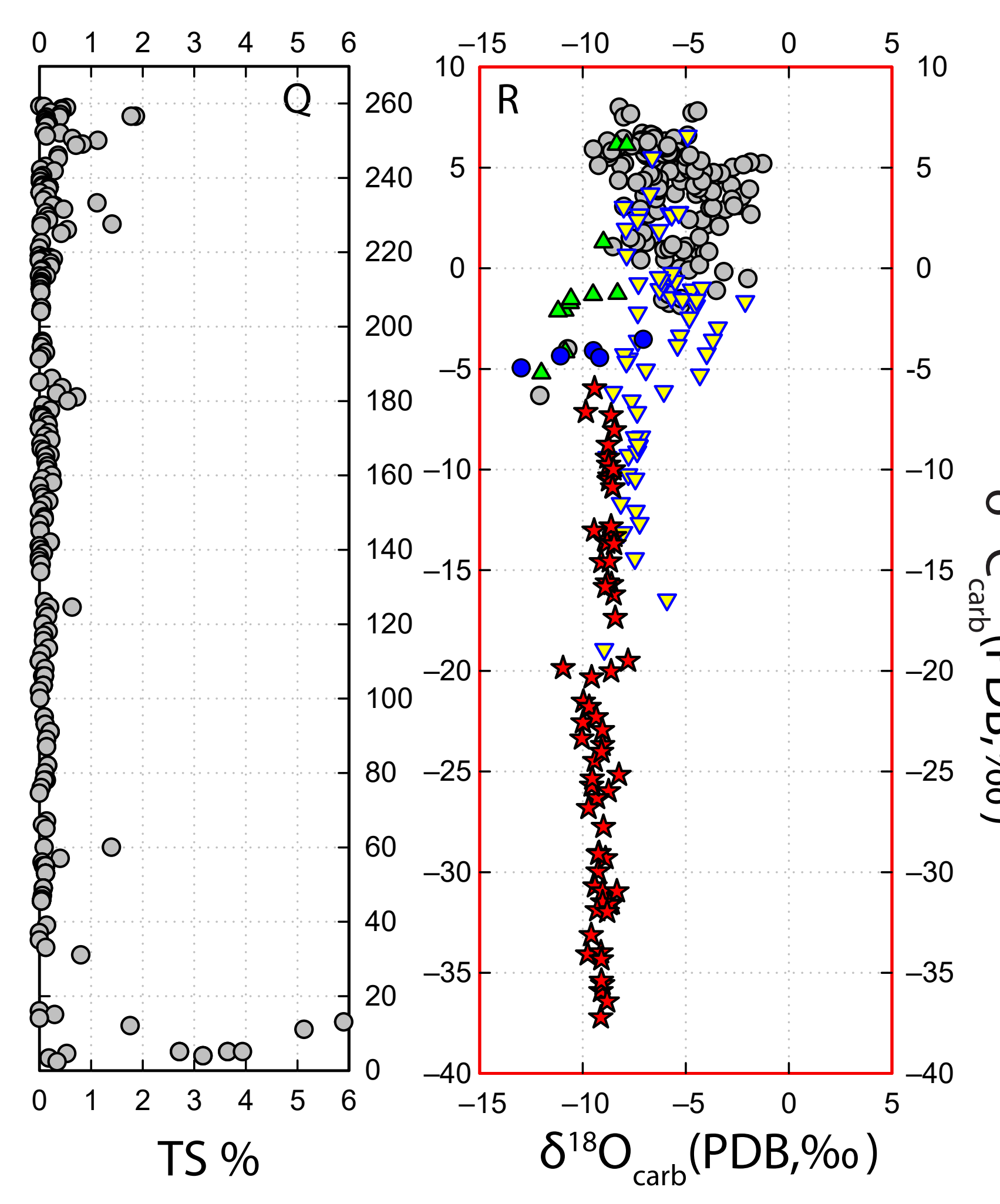



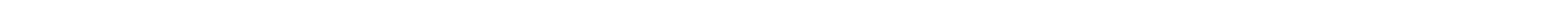


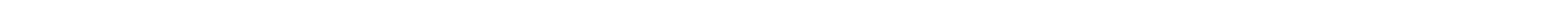




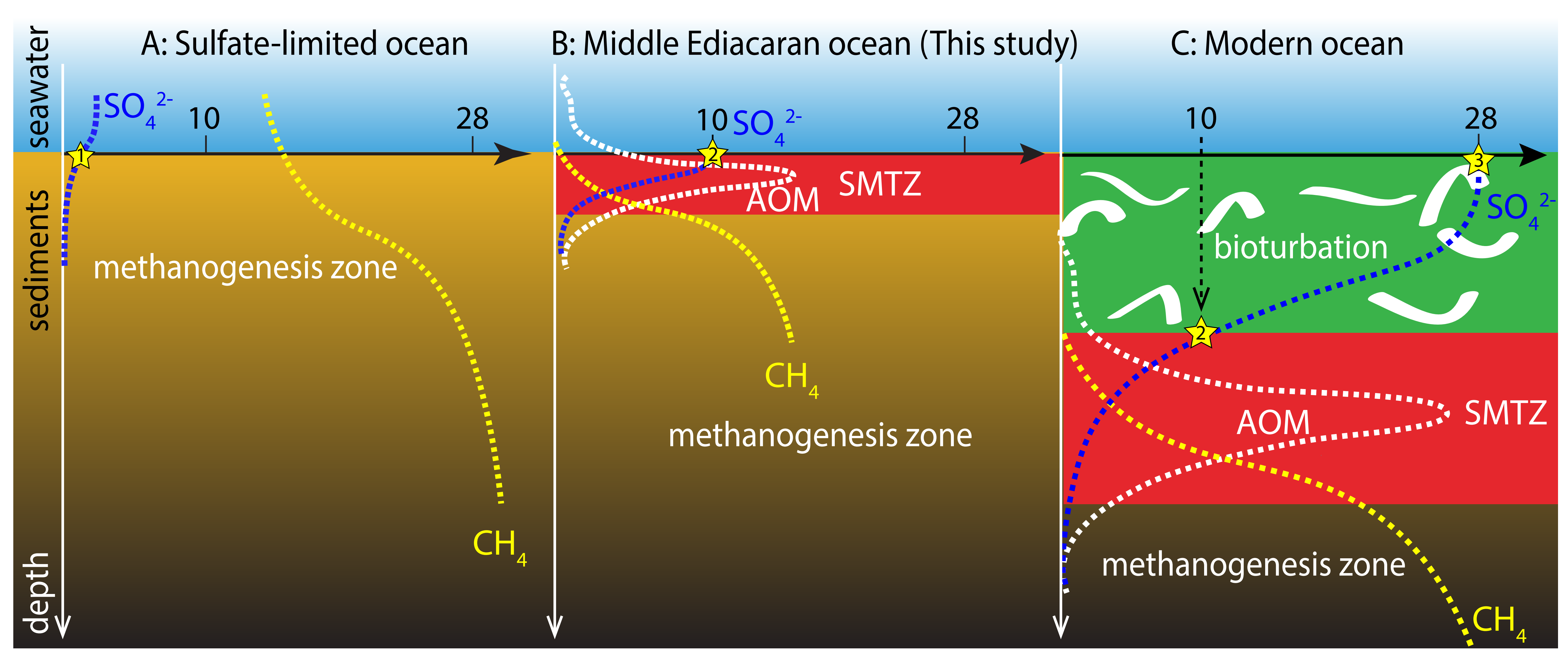


DY Shuram-equivelant EN3 interval of the Doushantuo Formation at the intra-shelf Jiulongwan section, South China

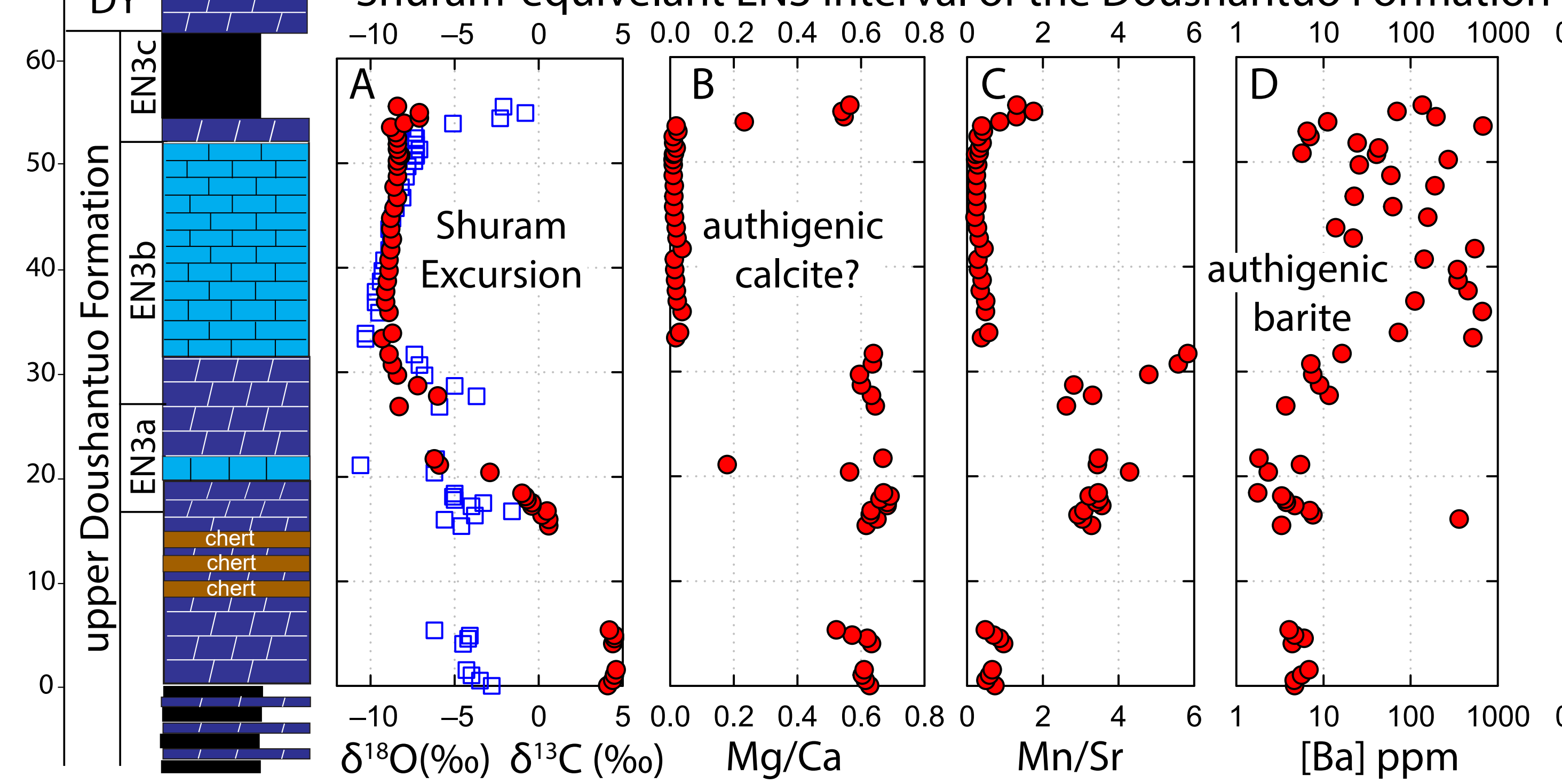

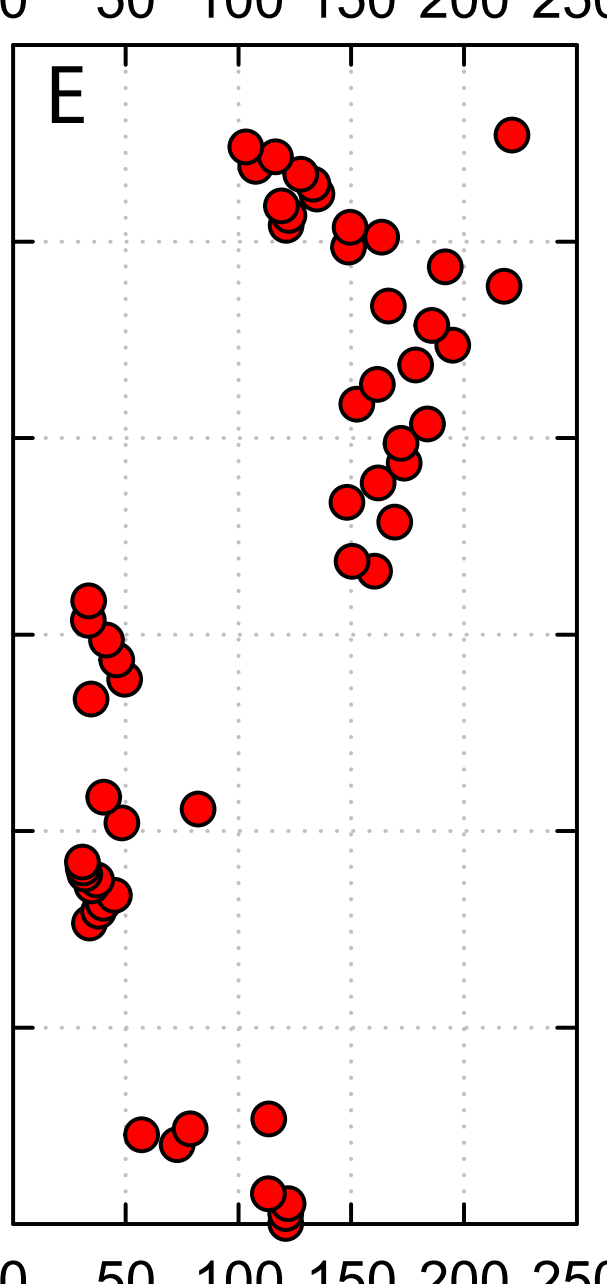

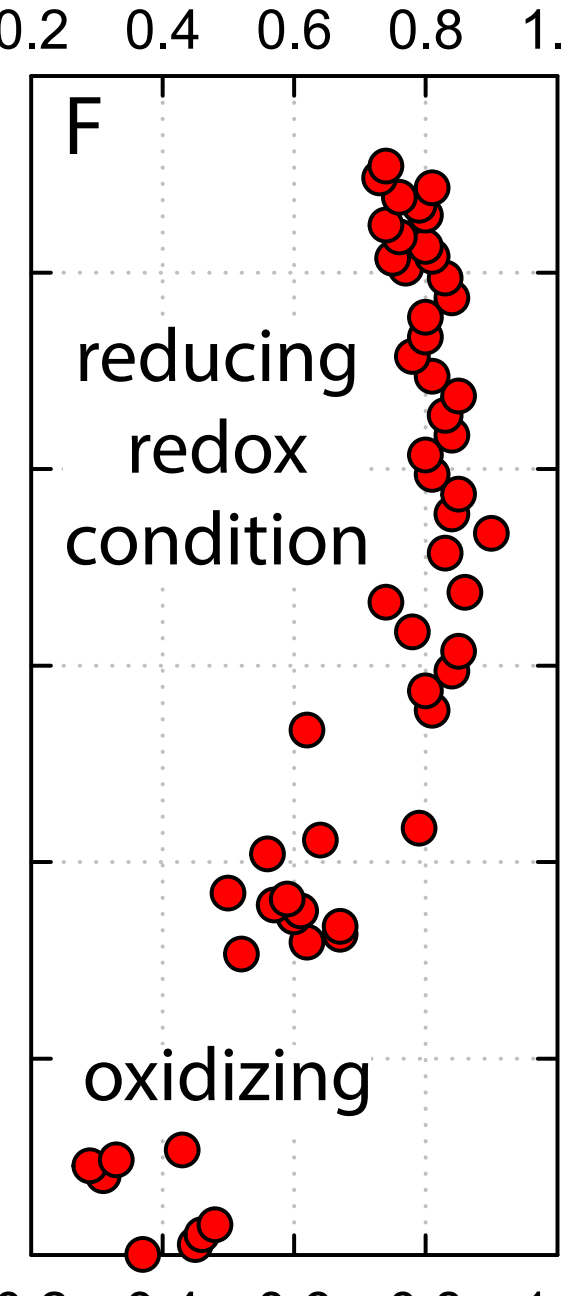

[Sr] ppm
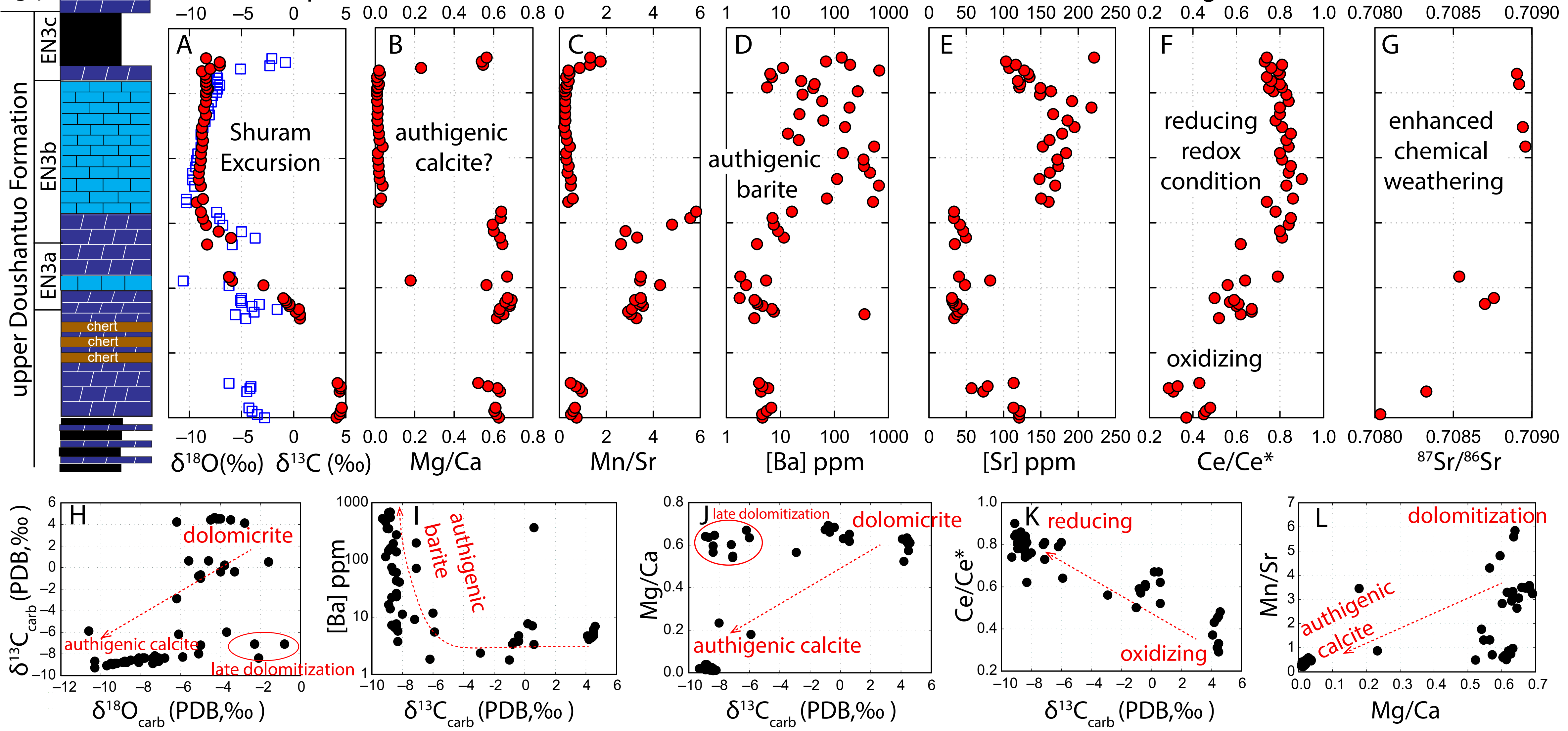

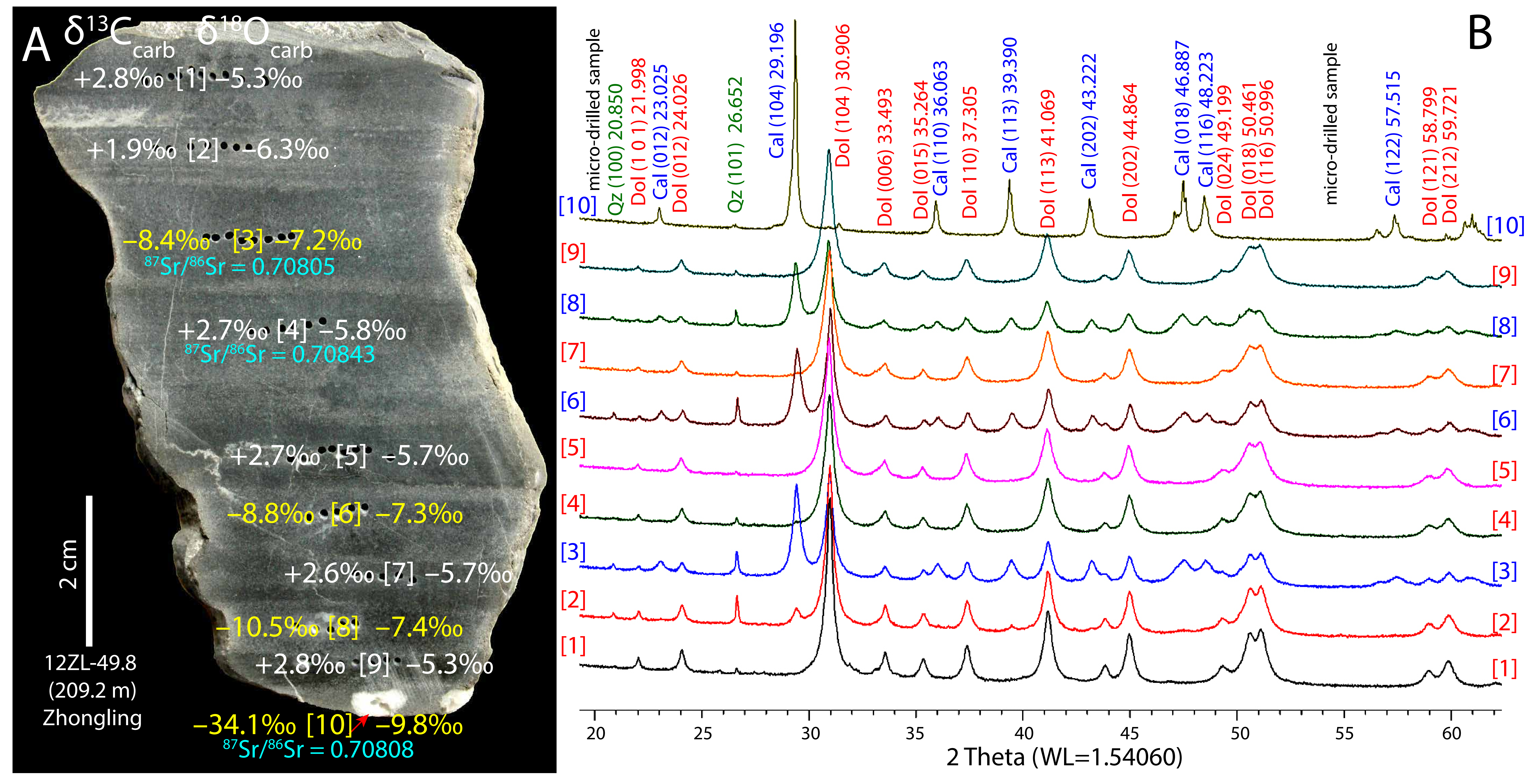
